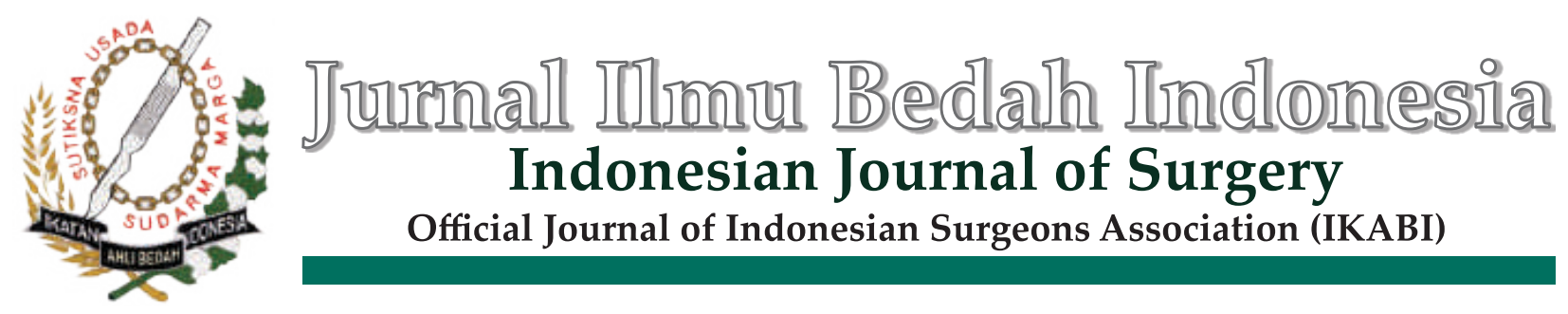




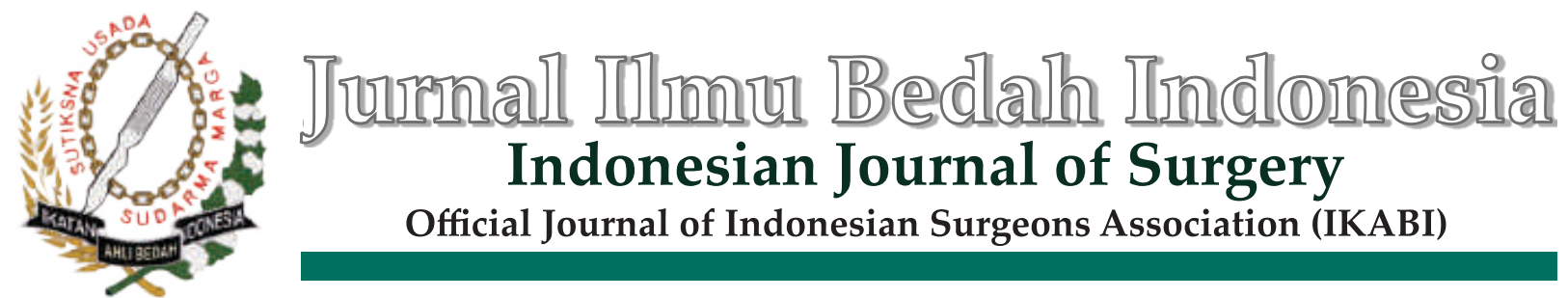

\title{
Editors
}

Patrianef, dr, $\operatorname{SpB}(\mathrm{K}) \mathrm{V}$

Departemen Bedah Fakultas Kedokteran Universitas Indonesia

RS dr Cipto Mangunkusumo, Jakarta

Dr. dr. Ibrahim Labeda, SpB.KBD

Departemen Bedah Fakultas Kedokteran Universitas Hasanuddin, Makassar

Dr. dr. Prihartono, SpB (K) Onk, M.Kes

Departemen Bedah Fakultas Kedokteran Universitas Hasanuddin, Makassar

Galih Wilatikta dr,

Departemen Bedah Fakultas Kedokteran Universitas Indonesia

RS dr Cipto Mangunkusumo, Jakarta

\section{Staff Redaksi}

Sdri. Tiwi

\author{
Alamat Redaksi \\ Jurnal Ilmu Bedah Indonesia (JIBI) \\ d/a Pengurus Pusat Perhimpunan Dokter Spesialis Bedah Indonesia (IKABI) Wisina Bhakti Mulya Lt 4 - 401 C \\ JI. Kramat Raya 160, Jakarta Pusat 10410, Tel. 021 3916774. e-mail: jurnalilmubedahindonesia@yahoo.com
}

\section{Jurnal Ilmu Bedah Indonesia}

Jurnal Ilmu Bedah Indonesia (JIBI) sebelumnya disebut Ropanasuri (Bahasa Sansekerta, berarti pisau bedah atau the healing knife yang diperkenalkan oleh Prof dr Moenadjat Wiratmadja) merupakan publikasi resmi dari Perhimpunan Dokter Spesialis Bedah Indonesia (IKABI) yang terbit pertama kali pada tahun 1968.

Pada perkembangan berikutnya (tahun 2001), sejalan dengan perubahan paradigma di bidang ilmiah, jurnal ini selanjutnya disebut Jurnal Ilmu Bedah Indonesia dan terakreditasi A berdasarkan keputusan Direktorat Jenderal Pendidikan Tinggi Departemen Pendidikan Nasional (SK No. 39/DIKTI/Kep/2004).

Jurnal Ilmu Bedah Indonesia (JIBI) diterbitkan oleh IKABI dengan ISSN No. 0216-0951 merupakan publikasi karya ilmiah di bidang bedah yang mencakup epidemiologi, klinik maupun pengetahuan dasar baik menyangkut kelainan kongenital, trauma, infeksi, tumor dan kelainan degeneratif yang ditujukan bagi para dokter spesialis bedah di Indonesia.

Jurnal ini diterbitkan oleh IKABI dua kali dalam satu tahun dalam bentuk cetakan yang dapat diakses dan diunduh dari situs web IKABI. Permintaan berlangganan dapat dikirimkan ke alamat sekretariat redaksi. Advertensi yang dapat dimuat pada jurnal ini hanya advertensi yang berhubungan dengan bidang medik khususnya bedah maupun bidang sains. Untuk pemuatan advertensi di dalam jurnal ini, dapat menghubungi sekretariat redaksi Jurnal Ilmu Bedah Indonesia (JIBI). Petunjuk bagi penulis beserta persyaratan pemuatan tulisan dapat dilihat pada halaman belakang jurnal ini, atau di situs web IKABI. 


\section{Jurnal Ilmu Bedah Indonesia}

Indonesian Journal of Surgery

\section{Editorial}

1 Patrianef Darwis

\section{Article}

3 Patrianef Darwis

Bakti H Simanjuntak

Grace Wangge

Deddy Pratama

Ahmad Bakri

Rizky Saputra Telaumbanua

17 Ike Yoganita Bangun

Jufriady Ismy

Dasrul Dasrul

33 Teuku Ronasky

Jufrialdy Ismy

Dasrul Dasrul

60 Patrianef Darwis

Yoni Vanto

82 Jauhari Deslo

Jufrialdy Ismy

Dasrul Dasrul

\section{Editorial}

Kenaikan Tarif BPJS Kesehatan, Obat Defisit yang Tak Bisa Dihindari

Factors Affecting Hospital Length of Stay in Patient with Diabetic Foot Ulcer

Pengaruh Vitamin E terhadap Kadar Malondialdehide Jaringan Testis Tikus (Rattus novergicus) Strain Wistar

Diabetes Mellitus Tipe I

Pengaruh Pemberian Vitamin E terhadap Morfologi Testis Tikus Strain Wistar (Rattus novergicus) dengan Diabetes Melitus Tipe I

Intervensi Endovaskular Aneurisma Aorta Torako-Abdominalis Pada Pasien dengan Sindrom Marfan: Tinjauan Literatur

Hubungan Kadar Malondialdehide (MDA) Testis dengan Kualitas Spermatozoa pada Tikus Putih Strain Wistar (Rattus novergicus) Diabetes Tipe I 


\title{
Kenaikan Tarif BPJS Kesehatan, Obat Defisit yang Tak Bisa Dihindari
}

\author{
Patrianef Darwis ${ }^{1}$ \\ ${ }^{1}$ Divisi Bedah Vaskular dan Endovaskular Departemen Ilmu Bedah Fakultas Kedokteran Universitas \\ Indonesia/ Rumah Sakit Cipto Mangunkusumo
}

Sejawat sekalian, memasuki tahun 2020 sangat banyak kejadian yang terjadi di dunia kesehatan. Masalah kenaikan tarif BPJS Kesehatan yang masih banyak dtentang oleh banyak pihak tentu saja mempengaruhi kerja para spesialis bedah secara keseluruhan. Pengaruh ini terjadi secara langsung karena sebagian besar pembiayaan pasien saat ini menggunakan dana Jaminan Kesehatan Nasional yang diselenggarakan oleh BPJS Kesehatan.

Berdasarkan pasal 34 Perpres nomor 75 tahun 2019 maka akan terjadi kenaikan iuran BPJS Kesehatan pada 1 januari 2020. Kenaikan itu secara rinci adalah sebagai berikut:

- Kelas III dari Rp 25.500 per bulan menjadi Rp 42.000
- Kelas II dari Rp 51.000 menjadi Rp 110.000

- Kelas I dari Rp 80.000 menjadi Rp 160.000

Kenaikan tersebut juga berlaku bagi Penerima Bantuan Iuran (PBI) baik dari APBN maupun PBI yang berasal dari APBD. Khusus untuk kenaikan iuran PBI yang dibayarkan pemerintah ini, akan terjadi kenaikan daari $\mathrm{Rp}$ 23.000 per bulan menjadi Rp 42.000.

Tentu saja kenaikan tersebut berpengaruh positif bagi seluruh rumah sakit yang banyak mengandalkan pasien BPJS Kesehatan, terutama rumah sakit di daerah.

Correspondents:

Patrianef Darwis

Divisi Bedah Vaskular dan Endovaskular

Departemen Ilmu Bedah Fakultas Kedokteran

Universitas Indonesia Rumah Sakit Cipto

Mangunkusumo

email : patrianef@gmail.com 
Pelayanan kesehatan selama ini terganggu karena aliran dana dari pembiayaan ke rumah sakit sering terlambat beberapa bulan. Hal itu tidak terlepas akibat defisit yang dialami oleh BPJS kesehatan yang semakin meningkat dari tahun ke tahun. Secara langsung aliran yang terhambat dan terlambat tersebut juga mempengaruhi para dokter yang bekerja di RS tersebut, termasuk dokter spesialis bedah.

Defisit yang dialami oleh BPJS Kesehatan sudah berlangsung sejak than 2014. Pada tahun 2018 defisit yang dialami oleh BPJS Kesehatan sebanyak Rp 19,4 T dan ditalangi oleh pemernah sebanyak $\mathrm{Rp}$ 10,3 $\mathrm{T}$ dan defisit dibawa ke tahun 2019 sebanyak Rp 9,1 T. Pada tahun 2019 defisit semakin melebar mencapai Rp 32,84 T ini termasuk beban defisit Rp 9,1 T yang dibawa ke tahun 2019. Pada tahun 2019 ini pemerintah menalangi defisit sebanyak Rp 14 Tsehingga ada beban defisit sebanyak Rp 18,84 T yang dibawa ke tahun 2020 .

Tanpa adanya kenaikan iuran maka beban defisit akan semakin melebar tahun 2020. Diperkirakan defisit tahun 2020 mencapai $\mathrm{Rp}$ $31 \mathrm{~T}$ dan ditambah dengan beban defisit tahun 2019 yang dbawa ke tahun 2020 sebanyak Rp 18 T maka defsit akan semakin melebar. Hal ini akan semakin memperburuk pelayanan di rumah sakit yang sudah tertekan oleh penundaan pembayaran pelayanan pasien beberapa bulan oleh BPJS Kesehatan.

Sejawat sekalian, kenaikan iuran BPJS kesehatan sepertinya memang keniscayaan yang tak dapat ditunda lagi dan sangat mendesak, hall ini akibat defisit yang dialami oeh BPJS Kesehatan yang sudah berlangsung 5 tahun terus menerus dan semakin membesar tetapi persoalannya adalah seberapa besar kenaikan tersebut dan apakah kenaikan tersebut masih mampu ditanggung oleh masyarakat. Kita paham bahwa orang miskin pembiayaannya ditanggung oleh pemerintah baik melalui dana APBN maupun dana APBD. Persoalannya adalah apakah semua orang miskin sudah terdata baik dan masuk dalam daftar penerima bantuan PBI.

Sebagai seorang spesialis bedah tentu saja kita tidak bisa berlepas diri dari gonjang ganjing di dunia kesehatan tersebut, apalagi hal ini menyangkut pembiayaan pasien kita. Bagaimanapun tindakan pada pasien yang dilakukan para spesialis bedah memerlukan pembiayaan yang tidak sedikit.

Harapan kita bersama tahun 2020 didepan akan lebih baik dari tahun lalu.

(ISSN:0216-0951 J Bedah Indonesia. 2019; 47:2) 


\title{
Factors Affecting Hospital Length of Stay in Patient with Diabetic Foot Ulcer
}

\author{
Patrianef Darwis ${ }^{1}$, Bakti H Simanjuntak ${ }^{2}$, Grace Wangge ${ }^{3}$, Deddy Pratama ${ }^{4}$, Ahmad Bakri ${ }^{5}$, \\ Rizky Saputra Telaumbanua ${ }^{6}$
1,2,4,5,6 Vascular and Endovascular Division, Department of Surgery, Faculty of Medicine Universitas Indonesia / Cipto Mangunkusumo General Hospital
${ }^{3}$ Departement of Community Medicine, Faculty of Medicine Universitas Indonesia

\begin{abstract}
Background. Foot ulcer is one of the most common complications in diabetes mellitus patients. This condition prolongs hospital length of stay (LOS) and increases hospitalization cost. This study aims to assess factors that affect the LOS in patients with the mentioned condition.

Methods. This is a retrospective cohort study of diabetes mellitus patients with foot ulcer who were hospitalized in Cipto Mangunkusumo General Hospital from January 2015 to April 2016. There were 120 patients recruited and then divided into two groups according to their hospitalization duration, which was short and long. Univariate analysis was conducted in predicted factors including gender, ankle-brachial index, ulcer size, ulcer depth, leukocyte count, treatment, cardiovascular comorbidity, blood pressure, smoking history, septicemia, ketoacidosis, hypoalbuminemia, and upper respiratory tract infection. Chi-Square tests were performed to analyze the association of those factors with LOS. The odds ratio of each variable was evaluated using logistic regression analysis.
\end{abstract}

Result. In this study, the mean of LOS was 26 days ( $2-87$ days). Factors that significantly correlated with LOS were ankle-brachial index ( $p$ 0.041, OR 2.275, CI 95 \% 1.025 - 5.041), ulcer size ( $p$ 0.044, OR 3.038, CI $95 \% 1.032$ - 9.942), smoking history ( $p$ 0.022, OR 2.434, CI $95 \%$ 1.125 - 5.265), sepsis ( $p<0.001$, OR 4.240, CI $95 \% 1.908-9.423)$, and ketoacidosis $(p<0.001$, OR 8.611, CI $95 \% 3.396$ - 21.835) In multivariate analysis, the most significant factor was ketoacidosis ( $\mathrm{p}<0.001$, OR 8.360, CI $95 \% 3.209-21.780)$.

Conclusion. Ketoacidosis is the most significant factor that prolonged hospital stays in a patient with diabetic foot ulcer.

Keywords: Diabetic foot ulcer, Length of stay 


\section{Introduction}

Diabetes mellitus is one of the world's most common health burdens. The global prevalence in 2019 was estimated by $9.3 \%$ (463 million people). ${ }^{1}$ Meanwhile in Indonesia, the disease's prevalence was $8.5 \%$ according to National Basic Health Research (RISKESDAS) 2018. ${ }^{2}$ This disease causes various complications and one of them is diabetic foot ulcer. The lifetime risk of diabetic foot ulcer in diabetic patient ranges from $15-20 \%{ }^{3}$ Most patients with diabetic foot ulcer will require hospitalization with various duration. A study at a Tertiary Hospital in Semarang, Indonesia, revealed that the mean length of stay (LOS) for patient with a diabetic foot ulcer was 17.8 days $(5-71$ days). ${ }^{4} \mathrm{~A}$ wide gap in LOS is determined by various factors. Therefore, this study aims to reveal those factors that affecting LOS in patient with diabetic foot ulcer. Understanding those factors might play an important role in improving strategies in managing patients with diabetic foot ulcer.

\section{Methods}

This was a single-centered, retrospective cohort study that was conducted at Cipto Mangunkusumo General Hospital (RSCM) in Jakarta, Indonesia. This study was approved by the Ethics Committee of Faculty of Medicine, University of Indonesia. Data were collected from medical record of patients both men and women with diabetic foot ulcer who were hospitalized at RSCM from January 2015 to April 2016. Patients who had died during treatment or underwent major amputation were exclude. We observed 12 independent variables among a total of 120 patients that were recruited using consecutive sampling.

Patients in this study were classified into two groups according to their LOS, which were short (below mean duration) and long (above or equal to mean duration). 
Data about factors that potentially affect LOS (independent variables) were collected. Those independent variables were (1) gender, (2) ankle-brachial index (ABI), (3) ulcer size, (4) ulcer depth, (5) leukocyte count, (6) treatment, (7) cardiovascular morbidity, (8) blood pressure, (9) smoking history, (10) septicemia (according SIRS criteria), (11) ketoacidosis (blood glucose $>250 \mathrm{mg} / \mathrm{dl}$, acidosis metabolic, ketonuria and/or ketonemia), and (12) hypoalbuminemia.

Analysis methods that were conducted in this study were univariate, bivariate, and multivariate analysis. Univariate analysis was performed on each independent variable to find a descriptive figure of each variable. Bivariate analysis with Chi-Square test was conducted to find the association of each independent variable with LOS. Finally, multivariate analysis using logistic regression model was conducted to know the odds ratio (OR) of each independent variable. A p-value $<0.05$ was considered significant. The analysis was carried out using SPSS 20.0 for Windows.

\section{Results}

Table 1 shows the result of observed variables from the subjects. LOS varied from $2-87$ days, with the mean duration of 26 days. Sixty seven patients were categorized as patients with short hospitalization duration and 53 patients as patients with long hospitalization duration. The distribution of men and women were relatively equal, with $53.33 \%$ and $46.67 \%$ respectively. Most patients had normal ABI (70.00\%), small or below $79 \mathrm{~cm}$ wound size (77.50\%), Wagner's grade 2 ulcer depth $(77.50 \%)$, and high leukocyte count (96.70\%). According to the treatment record, most patients were only treated with debridement (62.50\%). Most patients did not have cardiovascular comorbidity (81.67\%), smoking history $(65.83 \%)$, septicemia $(65.00 \%)$, or acute respiratory infection $(90.00 \%)$. However, $62.50 \%$ of patients included had ketoacidosis and $80.83 \%$ had hypoalbuminemia.

In bivariate analysis as presented in table 2, there were five factors that had statistically significant association with LOS, which were ABI $(p$ 0.041, OR 2.275, CI $95 \% 1.027$ 5.041), ulcer size ( $p$ 0.044, OR 3.038, CI $95 \%$ $1.032-9.942)$, smoking history ( $p 0.022$, OR 
2.434, CI $95 \% 1.125$ - 5.265), sepsis ( $p 0.000$, OR 4.240 CI $95 \% 1.908$ - 9.423), and ketoacidosis $(p<0.001$, OR 8.611, CI $95 \%$ $3.396-21.835)$.

Independent variables that had $p$-value $<0.25$ in the bivariate analysis were then included in the logistic regression test. The mentioned variables were ABI, ulcer size, leukocyte count, treatment, smoking history, sepsis, ketoacidosis, and upper respiratory tract infection. By using logistic regression test on those variables, we found three variables that had the most impact on LOS, which were ketoacidosis, ABI, and smoking history (table 3). However, ketoacidosis was the only factor that had statistically significant correlation with LOS $(p<0.001$, OR 8.360, CI $95 \% 3.209-$ 21.780).

\section{Discussion}

At present, there are very few studies that examine the factors affecting the LOS of patients with diabetic foot ulcer. The latest research is a study conducted by Choi et al. in 2017. That study was a retrospective study conducted among 164 patients at Konkuk University Chungju Hospital in South Korea.
The examined factors were sex, age, duration of diabetes, smoking status, body mass index, underlying comorbidities (hypertension and diabetic nephropathy), wound characteristics, number of wound, severity, type of surgery, leukocyte count, CRP levels, ESR, albumin, protein, HbA1c, and 7-days mean blood glucose level. In that study, factors that associate with LOS is wound severity (OR 1.423), leukocyte count (OR 1.423), C-reactive protein (OR 1.079), albumin (OR 0.263) and blood glucose (OR 1.018). ${ }^{5}$

As for our study, several new factors compared to previous studies have been found to have association with LOS. Those factors include $\mathrm{ABI}$, ulcer size, smoking history, sepsis, and ketoacidosis which have statistically significant association in bivariate analysis. However, after conducting multivariate analysis, ketoacidosis has been found to be the only independent predictor $(p<0.001$, OR 8.360, CI $95 \% 3.209$ $-21.780)$. Other factors in our study such as gender, ulcer depth, leukocyte count, treatment strategies, cardiovascular morbidity, blood pressure, hypoalbuminemia, and upper respiratory infection do not have significant correlation with LOS. 
Among a total of 120 patients included in this study, the distribution of subjects was $53 \%$ men and $47 \%$ women. Although gender shows no significant result in this study, this study descriptively shows that the number of diabetic foot ulcer in men and women at RSCM are relatively the same.

$\mathrm{ABI}$ is the ratio between the systolic blood pressure of the lower extremity, specifically the ankle, divided by the highest systolic in the upper extremity. This is a non-invasive method to screen peripheral arterial disease (PAD). ${ }^{6,7}$ Lower ABI indicates problems with blood flow, while adequate blood flow is needed in optimal wound healing. Therefore, patients with lower ABI will have disrupted wound healing process. Olivieri B et al. in 2018 stated that wound healing in patients with peripheral arterial disease often stops at one particular stage, most often at the inflammatory stage. ${ }^{8}$ This will ultimately prolong the hospitalization duration. Furthermore, our bivariate analysis shows that there is a correlation between ABI and LOS in chronic wounds, specifically diabetic foot ulcer ( $p$ 0.041, OR 2.275, CI $95 \%$ $1.027-5.041)$.

Jibiikabi.org
The influence of ulcer size on LOS has also been found to be one of the significant results on this study. Previous studies had examined the relationship between ulcer size and healing time but did not examine the ulcer size relationship with LOS. One such study is by Zimny et al. in 2004, in which they found that the greater the ulcer sizes the faster the wound radius reduction. However, when they examined it with healing time, the relationship was linear, as larger ulcer size will need a longer healing time. ${ }^{9,10}$ In our study, ulcer size were classified into three categories, which are small $(<79 \mathrm{~cm})$, medium $(79-141 \mathrm{~cm})$, and large $(141 \mathrm{~cm})$. We found that ulcer size has statistically significant association with $\operatorname{LOS}(p$ 0.044, OR 3.038, CI $95 \% 1.032$ - 9.942).

Sepsis is described as abnormal body's systemic immunological responses to infection. This is a medical emergency that can lead to end-stage organ dysfunction and death. ${ }^{11,12}$ Diabetes patients are prone to infection and sepsis due to immune deficiency with chronic inflammation and immune suppression. ${ }^{13}$ Center for Disease Control and Prevention (CDC) reported that patients hospitalized with septicemia had $75 \%$ longer LOS than patients hospitalized without septicemia. ${ }^{14}$ However, 
currently there is no study that specifically correlate sepsis with LOS in diabetic foot ulcer. This study confirms the effect of sepsis on LOS including and specifically in patient with diabetic foot ulcer $(p<0.001$, OR 4.240 CI 95 $\% 1.908-9.423)$. However, in the multivariate analysis, this finding was not statistically significant.

In our multivariate analysis with logistic regression test, it was found that the independent variable that remained consistently significant as a factor affecting the LOS is ketoacidosis $(p<0.001$ OR 8.360, CI $95 \%$ $3.209-21.780)$. Ketoacidosis is an acute and serious complication in diabetes. This is a metabolic emergency state consists of biochemical triad of hyperglycemia, ketonemia, and high anion gap. ${ }^{15,16}$ Currently there is no study examining the relationship between ketoacidosis and LOS in patient with diabetic foot ulcer. Study that still bears some resemblance is Choi et al.'s study, wherein that study they found that high blood glucose level prolonged LOS. However, this study has an important difference, in which the cut-off value that was used was the subjects mean blood glucose level which was $218 \mathrm{mg} / \mathrm{dL}^{5}$ Therefore, this study does not represent ketoacidosis, as the cut-off value of blood glucose level in ketoacidosis diagnostic criteria are $>250 \mathrm{mg} / \mathrm{dL}^{17}$ Moreover, ketoacidosis is not limited in hyperglycemia, but also includes ketonemia and high anion gap. ${ }^{15,16}$

There are several reasons why patient with ketoacidosis need longer treatment. First, because patients with ketoacidosis experience severe blood glucose dysregulation, whereas controlled blood glucose is an indicator of a patient can be discharged. Additionally, Melissa et al. has reported that the median LOS in diabetic ketoacidosis patient was 3 days. ${ }^{18}$ Second, most diabetic foot ulcer patient in this study have higher infection level (116 out 120 patients have high leukocyte count). Infection itself is one of the most common triggers of ketoacidosis. ${ }^{19}$ Combination of ketoacidosis and infection will probably result in prolonged LOS because controlled infection is also one of the discharge indicators in patient with diabetic foot ulcer.

\section{Conclusion}

In conclusion, in this study we found that ABI, ulcer size, smoking history, sepsis, and ketoacidosis are factors that have significant 
association with LOS in patient with diabetic foot ulcer. Among them, ketoacidosis was found to be the most significant factor. This is quite a new finding among studies of diabetic foot ulcer. However, we acknowledged, as a limitation in this study, that the medical record data was incomplete thus making it difficult for us to explore other factors. Other studies with bigger sample size and more factors needs to be conducted in order to make a more comprehensive scoring system to predict LOS in patient with diabetic foot ulcer.

(ISSN:0216-0951 J Bedah Indonesia. 2019; 47:2)

\section{References}

1. Saeedi P, Petersohn I, Salpea P, Malanda B, Karuranga S, Unwin N et al. Global and regional diabetes prevalence estimates for 2019 and projections for 2030 and 2045: Results from the International Diabetes Federation Diabetes Atlas, 9th edition. Diabetes Research and Clinical Practice. 2019;157:107843.

2. Kementerian Kesehatan Republik Indonesia. Hasil utama riskesdas 2018.
Jakarta: Badan Penelitian dan Pengembangan Kesehatan; 2018

3. Chun D, Kim S, Kim J, Yang H, Kim J, Cho $\mathrm{J}$ et al. Epidemiology and Burden of Diabetic Foot Ulcer and Peripheral Arterial Disease in Korea. Journal of Clinical Medicine. 2019;8(5):748.

4. Pemayun T, Naibaho R. Clinical profile and outcome of diabetic foot ulcer, a view from tertiary care hospital in Semarang, Indonesia. Diabetic Foot \& Ankle. 2017;8(1):1312974.

5. Choi S, Kim C, Jo D, Lee M, Kim J, Choi $\mathrm{H}$ et al. Factors Associated with a Prolonged Length of stay in Patients with Diabetic Foot: A Single-Center Retrospective Study. Archives of Plastic Surgery. 2017;44(6):539-544.

6. Pratama D, Ibrahim H, Suhartono R, Patrianef et al. Panduan Praktik Klinis RSCM: Lower extremity peripheral arterial disease. Jakarta: RSCM; 2019

7. McClary K, Massey P. Ankle Brachial Index (ABI) [Internet]. Ncbi.nlm.nih.gov. 2020 [cited 21 April 2020]. Available from: https://www.ncbi.nlm.nih.gov/books/N BK544226/ 
8. Yates $\mathrm{T}$, Vianna $\mathrm{S}$, Adenikinju $\mathrm{O}$, Beasley R, Houseworth J, Olivieri B. On the Cutting Edge: Wound Care for the Endovascular Specialist. Seminars in Interventional Radiology. 2018;35(05):406-426.

9. Zimny S, Schatz H, Pfohl M. The Effects of Ulcer Size on the Wound Radius Reductions and Healing Times in Neuropathic Diabetic Foot Ulcers. Experimental and Clinical Endocrinology \& Diabetes. 2004;112(04):191-194.

10. Zimny S, Pfohl M. Healing Times and Prediction of Wound Healing in Neuropathic Diabetic Foot Ulcers: a Prospective Study. Experimental and Clinical Endocrinology \& Diabetes. 2005;113(02):90-93.

11. Berg D, Gerlach H. Recent advances in understanding and managing sepsis. F1000Research. 2018;7:1570.

12. Gyawali B, Ramakrishna K, Dhamoon A. Sepsis: The evolution in definition, pathophysiology, and management. SAGE Open Medicine. 2019;7:205031211983504.

13. Frydrych L, Fattahi F, He K, Ward P, Delano M. Diabetes and Sepsis: Risk,
Recurrence, and Ruination. Frontiers in Endocrinology. 2017;8.

14. Hall MJ, Williams SN, Defrances SJ, Golosinskiy A. Inpatient care for septicemia or sepsis: a challenge for patients and hospitals. NCHS Data Brief. 2011;6(62):1-8

Ghimire P, Dhamoon A. Ketoacidosis [Internet]. Ncbi.nlm.nih.gov. 2020

[cited 26 April 2020]. Available from: https://www.ncbi.nlm.nih.gov/books/N BK534848/

15. Gosmanov A, Gosmanova E, Kitabchi A. Hyperglycemic Crises: Diabetic Ketoacidosis (DKA), And Hyperglycemic Hyperosmolar State (HHS) [Internet]. Ncbi.nlm.nih.gov. 2020 [cited 26 April 2020]. Available from:

https://www.ncbi.nlm.nih.gov/books/N BK279052/

16. Table 1, Criteria and classification of (DKA) - Endotext - NCBI Bookshelf [Internet]. Ncbi.nlm.nih.gov. 2020 [cited 26 April 2020]. Available from: https://www.ncbi.nlm.nih.gov/books/N BK279146/table/diab-

\section{ketoacidosis.table1crit/}


17. Lee M, Calder G, Santamaria J, MacIsaac R. Diabetic ketoacidosis in adult patients: an audit of factors influencing time to normalisation of metabolic parameters. Internal Medicine Journal. 2018;48(5):529-53 


\section{Tables}

Table 1. Characteristic of the subjects

\begin{tabular}{|c|c|c|}
\hline Variable & Total (n) & Percentage $(\%)$ \\
\hline \multicolumn{3}{|l|}{ Gender } \\
\hline Men & 64 & 53.33 \\
\hline Women & 56 & 46.67 \\
\hline \multicolumn{3}{|l|}{ Ankle Brachial Index (ABI) } \\
\hline Normal $(0.9-1.4)$ & 84 & 70.00 \\
\hline Abnormal & 36 & 30.00 \\
\hline \multicolumn{3}{|l|}{ Ulcer Size } \\
\hline Small $(<79 \mathrm{~cm})$ & 93 & 77.50 \\
\hline Medium $(79-141 \mathrm{~cm})$ & 10 & 8.33 \\
\hline Large $(>141 \mathrm{~cm})$ & 17 & 14.17 \\
\hline \multicolumn{3}{|c|}{ Ulcer depth (Wagner Classification) } \\
\hline Grade 1 & 3 & 2.50 \\
\hline Grade 2 & 93 & 77.50 \\
\hline Grade 3 & 15 & 12.50 \\
\hline Grade 4 & 9 & 7.50 \\
\hline \multicolumn{3}{|l|}{ Leukocyte } \\
\hline Normal & 4 & 3.30 \\
\hline $\operatorname{High}(>10.000)$ & 116 & 96.70 \\
\hline \multicolumn{3}{|l|}{ Treatment } \\
\hline Debridement & 75 & 62.50 \\
\hline Debridement + Amputation & 37 & 30.83 \\
\hline Debridemen + Revascularization & 8 & 6.67 \\
\hline
\end{tabular}


Cardiovascular comorbidity

Yes

22

18.33

No

98

81.67

\section{Blood pressure}

Hypertension

39

67.50

Normal

81

32.50

Smoking history

Yes

41

No

79

65.83

Sepsis

Yes

42

35.00

No

78

65.00

\section{Ketoacidosis}

Yes

75

62.50

No

45

37.50

\section{Hypoalbuminemia}

Yes

97

80.83

No

23

19.17

Acute respiratory infection

Yes

10.00

No

108

90.00

Length of stay

Short ( $\leq 26$ days $)$

67

55.83

Long ( $>26$ days)

53

44.16

\section{Total}

120


Table 2. Correlation between independent variable and LOS

\begin{tabular}{|c|c|c|c|c|c|}
\hline \multirow[b]{2}{*}{ Variable } & \multicolumn{2}{|c|}{ Length of stay (\%) } & \multicolumn{3}{|c|}{ OR } \\
\hline & Short & Long & $p$ & $\begin{array}{c}\text { (crude } \\
\text { ) }\end{array}$ & CI 95\% \\
\hline
\end{tabular}

\section{ABI}

Abnormal

$15(41.7) \quad 21(58.3)$

0.041

2.275

$1.027-5.041$

Normal

$52(61.9) \quad 32(38.1)$

Ulcer size

Small

Medium

Large

$\begin{array}{rrrrr}58(62.4) & 35(37.6) & 1 & 1 & 1 \\ 3(30) & 7(70) & \mathbf{0 . 0 6 1} & 3.867 & 0.938- \\ 6(35.3) & 11(64.7) & \mathbf{0 . 0 4 4} & 3.038 & 15.934 \\ & & & & 1.032-9.942\end{array}$

\section{Wagner Classification}

Grade 1

Grade 2

Grade 3

Grade 4

$\begin{array}{rrrrr}2(66.7) & 1(33.3) & 1 & 1 & 1 \\ 52(55.9) & 41(44.1) & 0.714 & 1.577 & 0.138- \\ 6(40) & 9(60) & 0.410 & 3 & 18.004 \\ 7(77.8) & 2(22.2) & 0.702 & 0.571 & 0.220- \\ & & & & 40.931 \\ & & & & 0.032- \\ & & & & 10.069\end{array}$

\section{Leukocyte}

$\operatorname{High}(>10.000)$

$54(53.5)$

$$
47(46.5)
$$

0.228

0.530

$0.187-1.505$

Normal

13 (68.4) $6(31.6)$

\section{Treatment}

Debridement

Debrid+amputation*

$\begin{array}{rrrrr}47(62.7) & 28(37.3) & 1 & 1 & 1 \\ 18(48.6) & 19(51.4) & 0.159 & 1.772 & 0.799-3.930 \\ 2(25) & 6(75) & 0.057 & 5.036 & 0.951-\end{array}$
26.679 
Debrid+revascularization

*

\section{Cardiovascular}

comorbidity

Yes

No

\section{Blood pressure}

Hypertension

Normal

\section{Smoking history}

Yes

No

Sepsis

Yes

No

Ketoacidosis

Yes

No

\section{Hypoalbuminemia}

Yes

No

$$
10(45.5) \quad 0.893 \quad 1.066 \quad 0.421-2.699
$$

$12(54.5) \quad 43(43.9)$

$55(56.1)$

$24(61.5) \quad 15(38.5) \quad 0.383 \quad 1.414 \quad 0.646-3.081$

$43(53.1) \quad 38(46.9)$

$17(41.5) \quad 24(58.5) \quad \mathbf{0 . 0 2 2} \quad 2.434 \quad 1.125-5.265$

$50(63.3) \quad 29(36.7)$

$14(33.3) \quad 28(66.7) \quad \mathbf{0 . 0 0 0} \quad 4.240 \quad 1.908-9.423$

$53(67.9) \quad 25(32.1)$

$29(38.7) \quad 46(61.3) \quad \mathbf{0 . 0 0 0} \quad 8.611 \quad 3.396-$

$38(84.4) \quad 7(15.6)$ 21.835

Acute respiratory tract

infection

$14(60.9) \quad 9(39.1) \quad 0.589 \quad 0.774 \quad 0.306-1.958$

53 (54.6) $44(45.4)$

Yes

$4(33.3) \quad 8(66.7) \quad 0.098 \quad 2.800 \quad 0.794-9.868$

No

$63(58.3) \quad 45(41.7)$

*debridement 
Table 3. Multivariate analysis

\begin{tabular}{lrrr}
\hline Variable & Adjusted OR & p-value & CI 95\% \\
\hline ABI & 0.473 & 0.103 & $0.193-1.164$ \\
Ketoacidosis & 8.360 & $\mathbf{0 . 0 0 0}$ & $3.209-21.780$ \\
Smoking history & 2.168 & 0.080 & $0.911-5.161$ \\
\hline
\end{tabular}




\title{
Pengaruh Vitamin E terhadap Kadar Malondialdehide Jaringan Testis Tikus (Rattus novergicus) Strain Wistar dengan Diabetes Mellitus Tipe I
}

\author{
Bangun, I. $Y^{1}$., Jufriadi Ismi ${ }^{2}$ dan Dasrul Dasrul ${ }^{3}$ \\ ${ }^{1}$ Program Pendidikan Dokter Spesialis Ilmu Bedah, Fakultas Kedokteran Universitas Syiah Kuala/ Rumah \\ Sakit Umum dr. Zainoel Abidin Banda Aceh. \\ ${ }^{2}$ Divisi Urologi, Departemen Bedah Fakultas Kedokteran Universitas Syiah Kuala/ Rumah Sakit Umum \\ dr. Zainoel Abidin Banda Aceh. \\ ${ }^{3}$ Staf Dosen Kedokteran Hewan, Fakultas Kedokteran Hewan Universitas Syiah Kuala/ Rumah Sakit \\ Umum dr. Zainoel Abidin Banda Aceh.
}

\begin{abstract}
Abstrak
Latar belakang. Diabetes mellitus (DM) merupakan kelainan endokrin yang menyebabkan kerusakan sistemik dan memicu stres oksidatif di tingkat seluler. Malondialdehide (MDA) adalah produk stres oksidatif berupa lipid peroksidase yang berhubungan dengan kondisi anomali dan asthenozoospermia. Upaya menekan stres oksidatif adalah dengan vitamin E yang telah lama menjadi antioksidan melawan stres oksidatif.

Tujuan Penelitian. Mengetahui pengaruh pemberian vitamin E terhadap kadar malondialdehide (MDA) serta pengaruh pemberian vitamin E dengan berbagai dosis terhadap kadar MDA.

Metode penelitian. Penelitian eksperimental menggunakan 30 ekor tikus putih strain Wistar jantan yang dibagi menjadi 5 kelompok perlakuan yaitu kelompok tikus tidak DM(KN), kelompok tikus DM (KP), kelompok tikus DM yang mendapat terapi vitamin E dosis $50 \mathrm{iu} / \mathrm{kgbb} / \mathrm{hr}(\mathrm{KP} 1)$, dosis $100 \mathrm{iu} / \mathrm{kgbb} / \mathrm{hr}$ (KP2) dan dosis $150 \mathrm{iu} / \mathrm{kgbb} / \mathrm{hr}$ (KP3). Pasca perlakuan dilakukan pengambilan organ testis pada semua kelompok dan dianalisis kadar MDA jaringan testis dengan metode Thiobarbituric Acid Reactive Subtances (TBARS). Analisis data kadar MDA jaringan testis menggunakan one way ANOVA $\alpha=0,05$ dengan uji lanjutan LSD.

Hasil penelitian. Pemberian vitamin E dapat menurunkan secara bermakna $(\mathrm{P}<0,05)$ kadar MDA jaringan testis tikus putih DM. Pemberian vitamin E dosis $150 \mathrm{iu} / \mathrm{kgbb} / \mathrm{hr}$ tidak berbeda secara nyata $(\mathrm{P}>0,05)$ dibandingkan dengan dosis $100 \mathrm{iu} / \mathrm{kgbb} / \mathrm{hr}$, namun keduanya berbeda secara nyata $(\mathrm{P}<0,05)$ dibandingkan dosis $50 \mathrm{iu} / \mathrm{kgbb} / \mathrm{hr}$.
\end{abstract}


Kesimpulan. Pemberian vitamin E dapat menurunkan kadar MDA testis tikus dengan kondisi diabetes mellitus tipe 1. Pemberian vitamin E dosis $150 \mathrm{iu} / \mathrm{kgbb} / \mathrm{hr}$ lebih baik dibandingkan dengan dosis $100 \mathrm{iu} / \mathrm{kgbb} / \mathrm{hr}$ dan $50 \mathrm{iu} / \mathrm{kgbb} / \mathrm{hari}$.

Kata kunci: vitamin E, diabetes mellitus, malondialdehide

(ISSN:0216-0951 J Bedah Indonesia. 2019; 47:2) 


\title{
Effect of Vitamin E on Malondialdehyde Level in Testicular Tissues of Wistar Strain White Mice (Rattus novergicus) with Diabetes Mellitus Type 1
}

\author{
Bangun, I. Y $Y^{1}$., Jufriadi Ismi ${ }^{2}$ dan Dasrul Dasrul ${ }^{3}$
}

\begin{abstract}
Background. Diabetes mellitus (DM) is the abnormality of endocrine that cause systemic damage and triggers oxidative stress in celluler level. Malondialdehide (MDA) is a product from oxidative stress, consist lipid, peroxide, and is related to anomaly condition and asthenozoospermia. The effort to suppres the oxidative stress is by using vitamin $\mathrm{E}$ that is known well for its function as antioxidane to oppose the oxidative stress.

Aims. To find the effect of vitamin E usage to the level of Malondialdehide and its effect with different dosage

Methods. Experimental study using 30 white male strain wistar mice divided into 5 treatment groups: non-DM group (KN), DM group (KP), rats with DM that was given Vitamin E 50 $\mathrm{IU} / \mathrm{kgbw} /$ day (KP1), $100 \mathrm{IU} / \mathrm{kg} /$ day (KP2) and $150 \mathrm{IU} / \mathrm{kgbw} /$ day (KP3). After intervention, mice testicles in all group were collected. The MDA level of the testicle tissue was analyzed with TBARS method. The data was analyzed with one way ANOVA $=0,05$ and continues with LSD test.

Results. Vitamin E usage can reduce ( $\mathrm{p}=0,05) \mathrm{MDA}$ level in testicle tissue of diabetic white rats. Vitamin E with dosage $150 \mathrm{iu} / \mathrm{kgbw} /$ day is not statistically different $(\mathrm{p}=0,05)$ comparing to 100 $\mathrm{iu} / \mathrm{kgbw} /$ day dosage, but both dosage is statistically different $(\mathrm{p}=0,05)$ comparing to dosage 50 $\mathrm{iu} / \mathrm{kgbw} /$ day
\end{abstract}

Conclusions. Vitamin E administration can reduce testicular MDA levels in mice with diabetes mellitus type 1 . Dosage of vitamin E up to $150 \mathrm{IU} / \mathrm{kg} /$ day is better than the lower dosages of 100 $\mathrm{IU} / \mathrm{kgbw} /$ day and $50 \mathrm{IU} / \mathrm{kgbw} /$ day.

Keywords. vitamin E, diabetes mellitus, malondialdehyde 


\section{Introduction}

Diabetes Mellitus (DM) is an endocrine disorder Related to oxidative stress and destruction of caused by increased of insulin resistance and spermatozoa in diabetes mellitus, decreased of insulin secretion due to the malondialdehyde, a molecular marker, which is dysfunction of $\beta$ cell that lead to hyperglycemia. an index of lipid peroxidation and a marker of In 2014, WHO estimated global prevalence of oxidative stress. MDA, a product of lipid diabetes has risen to $9 \%$ in adults over 18 years peroxidation, that is generated in constant of age and caused sexual in male due to proportion from the destruction of spermatogenesis impairment and erectile polyunsaturated lipid.

dysfunction. In worldwide, infertility occurred in

$15-20 \%$ sexually active couples that hopes to MDA is a good indicator for lipid peroxidation. have offspring but not pregnant within 1 year. MDA level in plasma has been reported to Idiopathic male infertility considered as an correlate with the survival, motility, morphology multifactorial disorder that is influenced by and low concentration of sperm. genetic and environment. Another reported factor is the presence of varicocele, urogenital Oxidative stress occurs in infertility induced by tract infection, endocrine metabolic disorder, diabetes mellitus, which requires molecular obesity, and abnormal congenital blockage of management in term of improving sperm semen duct. quality. One of the treatment is the use of vitamin E as an antioxidant. This primary antioxidant has properties as a free radical scavenger and breaks the peroxyl chain radical reaction by giving one hydrogen atom.

Correspondents:

Ike Yoganita Bangun

PPDS Ilmu Bedah

email : ike.yoganita.bangun@gmail.com 
These also occur with vitamin E, especially $\alpha$ tocopherol that acts as a radical reaction chain breaker antioxidant and also has potential as singlet oxygen scavenger and other reactive species via hydrogen atom transfer from 6hydroxil in chromanol ring together with superoxide dismutase (SOD) enzyme and GPx enroll in decreasing and prevention of lipid peroxidation reaction. There for, this study aimed to assess effect of vitamin $\mathrm{E}$ on malondialdehyde (MDA) in white mice testicular tissues with diabetes mellitus. Hopefully the result of this study can become a scientific based of vitamin $\mathrm{E}$ as antioxidant to prevent infertility in diabetes mellitus patient, so that it can become an alternative prevention and further management of the condition.

\section{Study Design}

This study was a laboratory experimental study using post-test only control group design. Each unit of population was homogen and has the same characteristic. The group selection used random assignment. The experimental group was given stimulus and observed the outcome, meanwhile the control group act as a comparison. The study was conducted in Laboratorium Terpadu Fakultas Kedokteran
Hewan Universitas Syiah Kuala Banda Aceh, from May to June 2017.

\section{Subject}

The subject of the study were male white mice rattus wistar, adults, aged 3-4 months, weight 200-220 grams, supplied by Fakultas Kedokteran Hewan Universitas Syiah Kuala. The subjects was randomly divided into 5 group, which was: KN: negative control group, mice without diabetes mellitus. KP: positive control group, mice with diabetes mellitus and received aquabidest as placebo. KP1: sample group of diabetes mellitus mice received a dosed of 50 $\mathrm{iu} / \mathrm{kg} /$ day vitamin E. KP2: sample group of diabetes mellitus mice received a dosed of 100 $\mathrm{iu} / \mathrm{kg}$ /day vitamin E. KP3: sample group of diabetes mellitus mice received a dosed of 150 $\mathrm{iu} / \mathrm{kg} /$ day vitamin E.

Inclusion criteria was white mice (rattus norwegicus) strain Wistar, in perfect health condition, aged 3-4 months, weight 200-220 grams, with fasting glucose blood level post induced $>126 \mathrm{mg} / \mathrm{dl}$ in experimental group. Exclusion criteria was mice with different genus and species, different strain. Drop out criteria was ill mice within adaptive period (inactive period), decreased of weight $>10 \%$ and death 
within study. The minimum samples for each group was 5 mice and with drop out consideration of $10 \%$, the samples of each group was 6 mice. Independent variable in this study was to received vitamin $\mathrm{E}$ in different doses, started from $50 \mathrm{iu} / \mathrm{kg} /$ day, $100 \mathrm{iu} / \mathrm{kg} /$ day to 150 $\mathrm{iu} / \mathrm{kg} /$ day. The dependent variable was malondialdehyde in term of malondialdehyde level in testicular tissue. Outer variable includes foods, water, genetics, sex, age, weight and temperature. Uncontrolled variable was the mice psychological.

Samples of 30 Rattus wistar mice, male, adult, aged 3-4 months. Received homogenization with monitoring the mice weight before received treatment, the rectal temperature and has underwent adaptive period for 2 weeks in cage. The cage temperature was set to room temperature. Every day the mice was feed with 20 grams pellet and water ad libitum. 24 mice was induced with $125 \mathrm{mg} / \mathrm{kg}$ alloxan intraperitoneal. After 4-7 days, the mice was fasted for 24 hours and was drawn $1 \mathrm{ml}$ of blood using $1 \mathrm{ml}$ syringe from the mice tail. Then it was examined using glucoDR glucose monitoring stick. Fasting glucose level $>126 \mathrm{mg} / \mathrm{dl}$ was considered as DM and was set to the experimental group. Vitamin E dosage used pure vitamin E powder of $50 \mathrm{iu}, 100 \mathrm{iu}$ and $150 \mathrm{iu}$ diluted with $2 \mathrm{ml}$ olive oil via sonde feeding. Glucose blood test was re-examined on day 28 .

Surgery was conducted in all five groups on day 31. The samples was sedated with chloroform. Surgery was attempted on the abdomen. The testis was rinsed using $0.9 \% \mathrm{NaCl}$ cold solution. It was then soaked in Phosphate Buffer Saline (PBS) with $\mathrm{pH} 7.4$ for Malondialdehyde (MDA) analyzation using Thiobarbituric Acid Reactive Substance (TBARS) methods. TBA/TCA/HCl reagent solution was solute with 4 times water.

The solution was stir using a magnetic stirrer and added BHT until reached a $0.03 \%$ of final concentration, testis lysate was centrifuged for 20 minutes with $8000 \mathrm{rpm} .100 \mu \mathrm{l}$ supernatant, that was produced by centrifugation, added with $550 \mu 1,100 \mu 1$ TCA and underwent vortex, then added with $250 \mu 1 \mathrm{HCl} 1 \mathrm{~N}$ and underwent vortex. Added again with $100 \mu \mathrm{l}$ NaThio $1 \%$ and underwent vortex again. After these, the solution was centrifugated for 15 minutes with $500 \mathrm{rpm}$. Supernatan that was produced by centrifugation was separated and moved to a new microtube. Afterward the solution underwent heating in $100^{\circ} \mathrm{C}$ water bath for 30 minutes. Sample was then measured with spectrophotometry in maximum length wave (532 $\mathrm{nm}$ ) for assessing 
the level of MDA from testicular lysate solution. After absorbance rate had been obtained, level of MDA was calculated by linear regression equation of a standard curve MDA solution.

Data analysis consist of descriptive criteria (body weight, vital sign, glucose blood level before and after treatment) and normality was analyzed with ShapiroWilk p>0.05, homogeneity was analyzed with Levence test and one way ANOVA. Then the data was analyzed with LSD test.

\section{Result}

The observation of white mice display by weight gain seen that the average weight of white mice during the study increased in all treatment groups. The longer the study, the heavier weight white mice were obtained. The average body weight of mice before treatment ranged between 189-194 grams, increased to $197,67-205,00$ gram after the administration of alloxan treatment that induced DM in mice and administration of vitamin $\mathrm{E}$ in group trial 1was $50 \mathrm{iu} / \mathrm{kgbw} /$ day, group trial 2 was 100 $\mathrm{iu} / \mathrm{kgbw} /$ day group trial 3 was $150 \mathrm{iu} / \mathrm{kgbw} /$ day. The highest weight gain of mice was found in the group without treatment $(\mathrm{KN})$ which was $10,83 \pm 3,87$ grams and the lowest weight gain of mice was found in group administer with

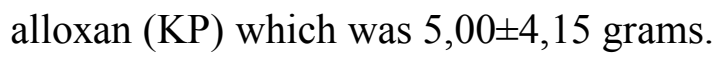

Statistical analysis of variance (ANOVA) with one way obtained significant value $0.00<0.05$, administration of vitamin $\mathrm{E}$ has an effect on reducing blood glucose levels in white mice with diabetes mellitus. The results of Post Hoc analysis with LSD test showed that the average vitamin $\mathrm{E}$ dose of $150 \mathrm{iu} / \mathrm{kgbw} /$ day had a significant difference to the positive control treatment group (KP) but does not have a difference with the administration dosage vitamin $\mathrm{E}$ of $50 \mathrm{iu} / \mathrm{kgbw} /$ day and dosage vitamin E of $100 \mathrm{iu} / \mathrm{kgbw} /$ day. These results indicate that the best dosage of vitamin $\mathrm{E}$ was 150 $\mathrm{iu} / \mathrm{kgbw} /$ day.

Testicular tissue MDA levels Rattus norvegicus mice in various treatment groups are presented in Table 2.

Statistical analysis of variance (ANOVA) with one way obtained significant value $0.044<0.05$, administration of vitamin $E$ has an effect on reducing blood glucose levels in white mice with diabetes mellitus. The results of Post Hoc 
analysis with LSD test showed that the average vitamin $\mathrm{E}$ dose of $150 \mathrm{iu} / \mathrm{kgbw} /$ day had a significant difference to the positive control treatment group (KP) but does not have a difference with the administration dosage vitamin $\mathrm{E}$ of $50 \mathrm{iu} / \mathrm{kgbw} /$ day and dosage vitamin $\mathrm{E}$ of $100 \mathrm{iu} / \mathrm{kgbw} / \mathrm{day}$. These results indicate that the best dosage of vitamin $\mathrm{E}$ was 150 iu/kgbw/day.

\section{Discussion}

Diabetic condition occurred after the mice had The blood level with dosage of vitamin E 50 been injected with alloxan. The diabetes iu/kgbw/day, $100 \mathrm{iu} / \mathrm{kgbw} / \mathrm{day}$ and 150 condition induced oxidative stress that were $\mathrm{mg} / \mathrm{kg} / \mathrm{day}$ were $271,20 \pm 271,20 \mathrm{mg} / \mathrm{dl}, 196,20$ related with an increase of MDA level in $\pm 75,38 \mathrm{mg} / \mathrm{dl}$ and $154,60 \pm 53,05 \mathrm{mg} / \mathrm{dl}$. testicular tissue. In baseline characteristic, an increase of body weight was in accordance with length of study. The longer length study resulted to a heavier white mice. The average weight before treatment was between 189-194 grams. There were an increase of body weight to 197.67-205.00 grams after injected with alloxan that induced diabetic in the samples. Vitamin E dosage for treatment 1 was $50 \mathrm{iu} / \mathrm{kg} /$ day, treatment 2 was $100 \mathrm{iu} / \mathrm{kg} /$ day and treatment 3 was $150 \mathrm{iu} / \mathrm{kg} /$ day. 
glucose will rise. Necrotizing of $\beta$ pancreatic cell after administration of alloxan was caused by increased production of oxygen reactive oxygen and caused in-homeostasis disturbance. Increased reactive oxygen formation is a major factor in pancreatic Langerhans $\beta$-island cell damage. Another study reported an increase in blood sugar levels due to alloxan, works directly on the pancreatic Langerhans $\beta$-island cells, stimulates the formation of hydrogen peroxide, damages the cell lysosomes and can cause degeneration and resorption of pancreatic cells which can cause insulin deficiency. Similarly, the vital function of cells as a provider of insulin hormone is also disrupted, because lipid peroxidation causes an increase in cell membrane permeability.

The production of insulin hormone becomes reduced, and also its function, so it is unable to use glucose into the tissue. This condition causes the blood glucose blood level to risen.

The results of measurement of blood glucose levels in diabetes mellitus mice induced by alloxan and administration of vitamin $\mathrm{E}$ at a dose of 50-150 iu $/ \mathrm{kgbw} /$ day showed a marked decrease compared to alloxan-induced diabetes mellitus mice (KP). These results prove that vitamin $\mathrm{E}$ in mice with diabetes mellitus has an effect on reducing fasting blood glucose levels in rats with diabetes mellitus. The decrease in blood glucose levels in diabetic mice after administration of vitamin $\mathrm{E}$ may be caused by the repair $\beta$ cells of the islets of Langerhans of the pancreas through its function as antioxidants to prevent or terminate the chain reaction of free radicals. As reported by Kusuma in 2005 that chemicals that contain antioxidants can reduce the activity of free radicals and protect the langerhans islet from damage or oppose the cytotoxic effects. Furthermore, Watkins in 2008 reported substance that contain antioxidants have been shown to reduce free radicals and protect pancreatic cells from the effects of diabetogenic agents such as streptosizine (STZ).

\section{The effect of vitamin $E$ on testis MDA level on}

\section{diabetes mellitus mice Rattus novergiccus}

Malondialdehyde was formed from lipid peroxidation on the cell membrane in the cell membrane of reactions with free radicals (hydroxyl radical) with Poly Unsaturated Fatty Acid (PUFA). The reaction occurs in a chain, with the final product of the chain reaction was hydrogen peroxide. Hydrogen peroxide can cause decomposition of some aldehyde products 
which were toxic to cells and affect the increased $\mathrm{iu} / \mathrm{kgbw} / \mathrm{day}$. These results indicate that the best risk of infertility and testicular fertility disorders. dosage of vitamin E was $150 \mathrm{iu} / \mathrm{kgbw} /$ day in suppressing MDA in testicular tissue of mice

The results of the evaluation of testicular MDA with diabetes mellitus. levels in each treatment group, was found that the mean MDA testis showed the highest value The results of this study confirm that the diabetes in the control positive group (KP) $24,286 \pm$ mellitus can lead to an increase in MDA. MDA $10,969 \mu \mathrm{g} / \mathrm{gr}$. Meanwhile in the group given systemically been reported to have relation with several doses of vitamin E, showed a decrease metabolic parameters in subjects with diabetes compared to the group KP. The mean value of type I and II. It has been reported that patients MDA testis in each vitamin E administration (50, with poor metabolic control will show the 100, $150 \mathrm{iu} / \mathrm{kgbw} /$ day) were 13,931 \pm highest plasma MDA concentration, $9,146 \mu \mathrm{g} / \mathrm{gram}, \quad 12,995 \pm 6,103 \mu \mathrm{g} / \mathrm{gram}$ and significantly different from the group with better $10,995 \pm 4,680 \mu \mathrm{g} / \mathrm{gram}$. control. This phenomenon may occur either due to increased glycosylation and aggregation of The lowest testicular MDA was shown in the platelets, or damage to cellular antioxidative group given dosage vitamin $\mathrm{E}$ of 150 protective system. Increased production of free $\mathrm{iu} / \mathrm{kgbw} /$ day with value of $10,995 \pm 4,680$ radicals can play a role in the pathogenesis of $\mu \mathrm{g} / \mathrm{gram}$. The difference in mean values of MDA metabolic vasculopathy and various cell damage levels in each group also showed significant due to DM that induces MDA. ${ }^{33}$ Nakhjavani et values ( $p$ value $=0,044$ ) so it can be explained that the administration of vitamin $\mathrm{E}$ affects MDA. The results of Post Hoc analysis with LSD al. also reported that MDA levels were significantly increased in DM patients compared test showed that the average vitamin $\mathrm{E}$ dose of $150 \mathrm{iu} / \mathrm{kgbw} /$ day had a significant difference to with controls ( $p<0,001)$, and to those who suffering from diabetes over 120 months compared to DM for 120 months or less $(\mathrm{P}<$ the positive control treatment group (KP) but 0,001). Levels of MDA are significantly does not have a difference with the correlated with the duration of suffering from administration dosage vitamin $\mathrm{E}$ of $50 \mathrm{DM}$. $\mathrm{iu} / \mathrm{kgbw} /$ day and dosage vitamin $\mathrm{E}$ of 100 
In the mechanism of oxidative stress mechanism of vitamin E suppressed the MDA is accompanied by an increase in MDA, the thought to occur through this primary condition of infertility in men may occur as a antioxidant effect as a free radical scavenger and result of damage to the testes and spermatozoa. break the chain reaction with peroxyl radicals by The study of Colagar et al. also supports that donating one atom and together with the SOD MDA can damage testicular tissue, reported enzyme, so that it can slow down and prevent the MDA concentrations in infertile male semen onset of lipid peroxidation reactions in which plasma $(0,94 \pm 0,28 \mathrm{nmol} / \mathrm{ml})$ are significantly higher than fertile male $(0,65 \pm 0,17 \mathrm{nmol} / \mathrm{ml})(\mathrm{p}$ finally suppress the production of MDA.,8 value $<0,001$ ), and have a negative relation with sperm quantity and morphology, and concluded that the increase in lipid peroxidation was associated with the sperm membrane damage and high levels of MDA. These findings suggest that excess ROS production from MDA may play a role in the mechanism of testicular degeneration which was related to infertility. Another study by Jain et al.1997, also confirm the benefit of vitamin $\mathrm{E}$ to suppress MDA in diabetes mellitus condition and also the evaluation of major protein glycosylation that was present on the diabetes mellitus conditions decreased by administering vitamin E. In these experimental animals there was a decrease in glycosylation through inhibition of MDA. In the study MDA and all activities of oxidative stress that cause cell injury was also decreased and In this study, vitamin E was administered as an antioxidant in experimental animals with diabetes mellitus, evaluation of an increase in testicular MDA was performed as an indicator of oxidative stress in the testis and its relationship with infertility. by administering several doses of vitamin $\mathrm{E}$ showed that MDA has a significant MDA biomarkers.

decrease. This is thought to occur due to the role of vitamin $\mathrm{E}$ which is able to improve oxidative stress conditions due to DM through a decrease in the results of lipid peroxidation. The 


\section{Conclusion}

Vitamin E can significantly decreased MDA level in testicular tissue of mice with diabetes mellitus ( $\mathrm{p}=0.004)$. Vitamin $\mathrm{E}$ dosage also has an effect to reduce the MDA level in the testicular tissue of mice with diabetes mellitus. Dose of $150 \mathrm{iu} / \mathrm{kgbw} /$ day vitamin had a higher reduce effect of MDA level than $100 \mathrm{iu} / \mathrm{kgbw} /$ day and $50 \mathrm{iu} / \mathrm{kgbw} /$ day vitamin $\mathrm{E}$.

\section{Reference}

1. Dohle G. Male Factors in Couple's Infertility. Clinical Uro-Andrology: Springer; 2015. p. 197-201.

2. Collodel G, Moretti E, Micheli L, Menchiari A, Moltoni L, Cerretani D. Semen characteristics and malondialdehyde levels in men with different reproductive problems. Andrology. 2015;3(2):280-6.

3. Reilly CA, Aust SD. Measurement of lipid peroxidation. Current protocols in toxicology. 2001:2.4. 1-2.4. 13.

4. Turchi P. Prevalence, Definition, and Classification of Infertility. Clinical Management of Male Infertility: Springer; 2015. p. 5-11.

5. Agarwal A, Mulgund A, Hamada A, Chyatte MR. A unique view on male infertility around the globe. Reprod Biol Endocrinol. 2015;13:37-46.

6. Gallardo JM. [Evaluation of antioxidant system in normal semen]. Revista de investigacion clinica; organo del Hospital de Enfermedades de la Nutricion. 2006;59(1):42-7.

7. Winarsi H. Antioksidan Alami dan Radikal: Kanisius; 2005.

8. Giammusso B. Dietary Complements and Phytotherapy. In: Cavallini G, Beretta G, editors. Clinical Management of Male Infertility. London: Springer; 2015. p. 153-5.

9. Hiferi, Perfitri, IAUI, POGI. Konsensus penanganan infertilitas. Jakarta2013.

10. Jungwirth A, Giwercman A, Tournaye H, Diemer T, Kopa Z, Dohle G, et al. European Association of Urology guidelines on Male Infertility: the 2012 update. European urology. 2012;62(2):324-32.

11. Zhang W, Doherty M, Peat G, Bierma-Zeinstra SM, Arden N, Bresnihan B, et al. EULAR evidence based recommendations for the diagnosis of knee osteoarthritis. Annals of the rheumatic diseases. 2009.

12. Cavallini G, Beretta G. Clinical Management of Male Infertility: Springer; 2015.

13. Winters BR, Walsh TJ. The epidemiology of male infertility. Urologic Clinics of North America. 2014;41(1):195-204.

14. Purnamasari D. Diagnosis dan Klasifikasi Diabetes Mellitus. In: Sudoyo AW, Setiyohadi B, Alwi I, Simadibrata M, Setiati S, editors. Buku Ajar Ilmu Penyakit Dalam Jilid 
III 5ed. Jakarta: Interna publishing; 2009. p. 1880-3.

15. Suarsana IN, Utama IH, Agung IG, Suartini A. Pengaruh hiperglikemia dan vitamin $\mathrm{E}$ pada kadar malonaldehida dan enzim antioksidan intrasel jaringan pankreas tikus. Majalah Kedokteran Bandung. 2011;43(2):72-6.

16. Braun J.V., Van den Berg R, Baraliakos X, Boehm H, BurgosVargas R, Collantes-Estevez E, et al. 2010 update of the ASAS/EULAR recommendations for the management of ankylosing spondylitis. Annals of the rheumatic diseases. 2011;70(6):896-904.

17. Faranita OV. Kualitas Spermatozoa pada Tikus Wistar Jantan Diabetes Melitus: Medical faculty; 2009.

18. Rudijanto A, Kalim H. Pengaruh Hiperglikemi Terhadap Peran Sitoskeleton (Cytoskeleton) Sebagai Jalur Tranduksi Signal (Signal tranduction). journal of internal medicine. 2006;7(3).

19. Hammam NR. Pengaruh Pemberian Minyak Jintan Hitam (Nigella Sativa) terhadap Jumlah Spermatozoa Mencit Diabetes Melitus yang diinduksi Aloksan: Faculty of Medicine; 2008.

20. Yang J, Liu X, Bhalla K, Kim CN, Ibrado AM, Cai J, et al. Prevention of apoptosis by Bcl-2: release of cytochrome $\mathrm{c}$ from mitochondria blocked. Science. 1997;275(5303):1129-32.

21. Vignera S, Condorelli R, Vicari E, D'Agata R, Calogero AE. Diabetes mellitus and sperm parameters.
Journal of andrology. 2012;33(2):14553.

22. Bashandy AS. Effect of fixed oil of Nigella sativa on male fertility in normal and hyperlipidemic rats. Int $\mathrm{J}$ Pharmacol. 2007;3(1):27-33.

23. Siswonoto S. Hubungan Kadar Malondialdehid Plasma dengan Keluaran Klinis Stroke Iskemik Akut: Program Pasca Sarjana Universitas Diponegoro; 2008.

24. Dröge W. Free radicals in the physiological control of cell function. Physiological reviews. 2002;82(1):47-95.

25. Frei B. Natural antioxidants in human health and disease: Academic Press; 2012.

26. Block G, Dietrich M, Norkus EP, Morrow JD, Hudes M, Caan B, et al. Factors associated with oxidative stress in human populations. American Journal of Epidemiology. 2002;156(3):274-85.

27. Mudassir, Azis A, Punagi AQ. Analysis on Plasma Malondialdehid (Mda) Content of Patients with Nasal Polyps Based on Inflammation Cell Domination Through Histiopathology Examination. Makassar: Bagian Ilmu Kesehatan Telinga Hidung Tenggorok - Kepala Leher Fakultas Kedokteran Universitas Hasanuddin, 2012.

28. Adibhatla RM, Hatcher J. Phospholipase A 2, reactive oxygen species, and lipid peroxidation in cerebral ischemia. Free Radical Biology and Medicine. 2006;40(3):376-87. 
29. Halliwell B, Gutteridge JM. Free radicals in biology and medicine: Oxford University Press, USA; 2015.

30. Burcham PC. Genotoxic lipid peroxidation products: their DNA damaging properties and role in formation of endogenous DNA adducts. Mutagenesis. 1998;13(3):287-305.

31. Dalle-Donne I, Rossi R, Colombo R, Giustarini D, Milzani A. Biomarkers of oxidative damage in human disease. Clinical chemistry. 2006;52(4):601-23.

32. Doria A, Iaccarino L, Arienti S, Rampudda M, Canova M, Rondinone $\mathrm{R}$, et al. Mycophenolate mofetil and systemic lupus erythematosus. Lupus. 2006;15(11 suppl):44-54.

33. Scholichah, N. A., Aulanni'am, dan Chanif, M. Efek Terapi Ekstrak Air Daun Kedondong (Lannea coromandelica) terhadap Kadar Malondialdehid (MDA) dan Aktivitas Protease pada Ileum Tikus Putih (Rattus norvegicus) Inflammatory Bowel Disease (IBD) Akibat Paparan Indometasin. Veterinaria Medika 5(3). 2012: 187-194.

34. Hermiyanti, P., Mukono, H. J., and Notopuro, H. Lipid Peroxidation and Respiratory Disorders to The Workers Pool. International Journal of Scientific Research and Management 3(7): 2015. 3301-3304

35. Kusumowardhani. Ramuan Sambiloto Untuk Pencegahan dan Pengobatan. Tanaman Obat Herba 3. 2005.

36. Nurdiana,.N.P., Setyawati dan M. Ali. Efek Streptozotocin Sebagai Bahan
Diabetogenik Pada Tikus Wistar dengan Cara Pemberian Intraperitonial dan Intravena. Majalah Kedokteran Unibraw. Vol XIV, No 2: 1998. hal 66-77. 19

37. Subandrate. Hubungan Kadar Glukosa Darah dengan Peroksidasi Lipid pada Pasien Diabetes Melitus tipe 2. CDK-242/ vol. 43 no. 7 th. 2016

38. Aitken, R. J. and Roman, S. D. Antioxidant System and Oxidative Stress in The Testes. Oxidative Medicine and Cellular Longevity 1(1). . 2008: 15-24.

39. Yuriska AF. Efek Aloksan Terhadap Kadar Glukosa Darah Tikus Wistar. 2009: 1-45.

40. Maslachah, L., Sugihartuti, R., dan Kurniasanti, R. Hambatan Produksi Reactive Oxygen Species Radikal Superoksida (O2-) oleh Antioksidan Vitamin E ( $\alpha$-Tocopherol) pada TIkus Putih (Rattus norvegicus) yang Menerima Stressor Renjatan Listrik. Media Kedokteran Hewan 24(1). 2008: 21-26.

41. Suarsana IN, Utama IH, Agung IG, Suartini A. 2011. Pengaruh hiperglikemia dan vitamin E pada kadar malonaldehida dan enzim antioksidan intrasel jaringan pankreas tikus. MKB. 43(2):72-26

42. Jain SK, Palmer M. The Effect of Oxygen Radicals Metabolites and Vitamin $\mathrm{E}$ on Glycosylation of Proteins. Free Radic Biol Med. 1997;22(4):593-6.

43. Aybek H, Aybek Z, Rota S, Sen N, Akbulut M. The effects of diabetes mellitus, age, and vitamin $\mathrm{E}$ on 
testicular oxidative stress. Fertil Steril. 2008 Sep; 90(3):755-60. PMID: 17482598

44. Nakhjavani M, Esteghamati A, Nowroozi S, Asgarani F, Rashidi A, Khalilzadeh O. Type 2 diabetes mellitus duration: an independent predictor of serum malondialdehyde levels. Singapore Med J. 2010;51(7):582.

45. Colagar AH, Pouramir M, Marzony ET, Jorsaraei SGA. Relationship between seminal malondialdehyde levels and sperm quality in fertile and infertile men. Brazilian Archives of Biology and Technology. 2009;52(6):1387-92.

46. Hsieh Y-Y, Chang C-C, Lin C-S. Seminal malondialdehyde concentration but not glutathione peroxidase activity is negatively correlated with seminal concentration and motility. Int $\mathrm{J}$ Biol Sci. 2006;2(1):23-9.

Table 1. The average blood glucose levels of Wistar diabetes white mice induced by alloxan after treatment with various levels of doses of vitamin $\mathrm{E}$ for 28 days

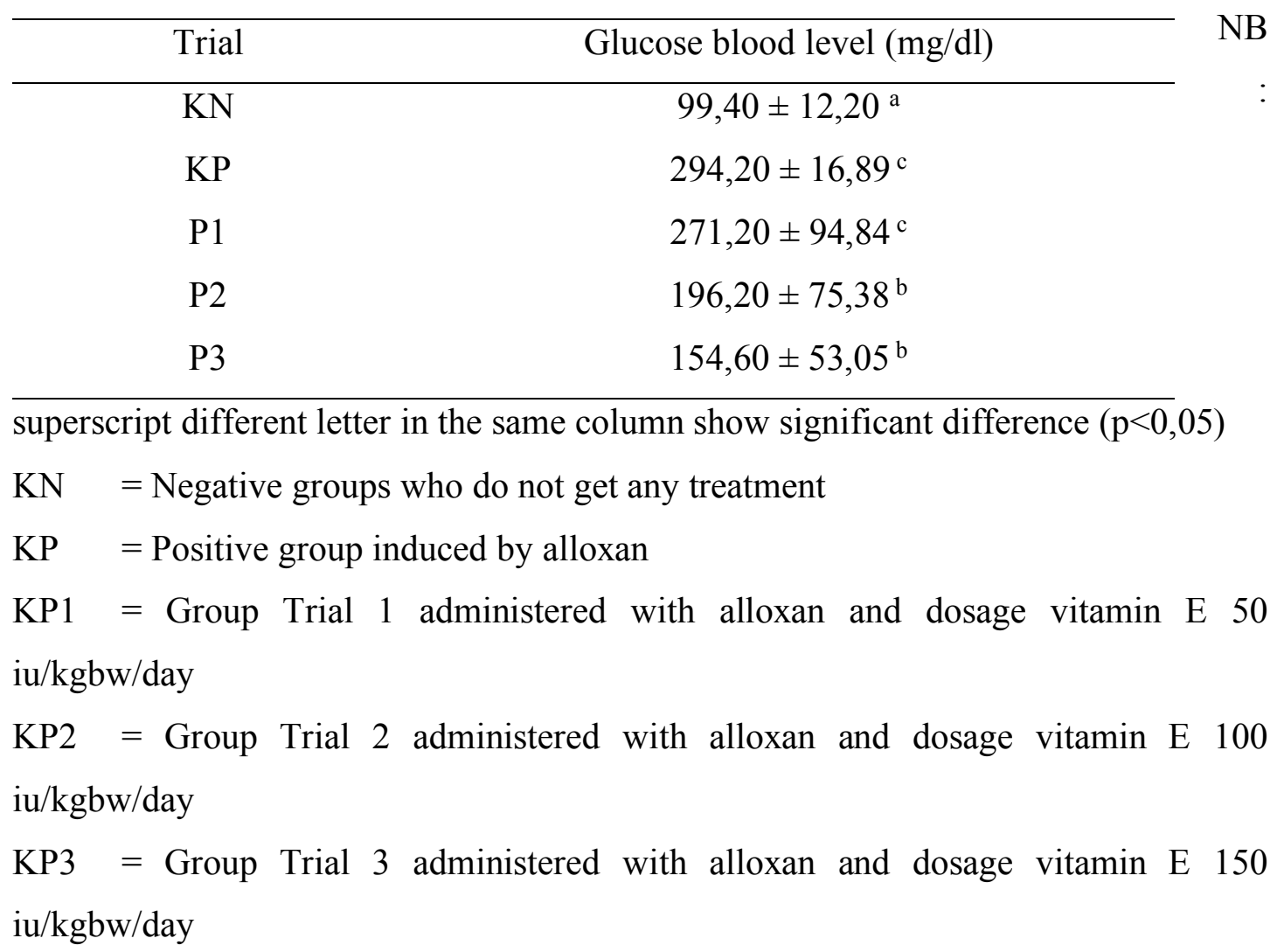


Table 2. The average levels of MDA testis in Wistar diabetes white mice induced by alloxan after treatment with various levels of vitamin $\mathrm{E}$ for 28 days.

NB : superscript different letter in the same column show significant difference $(\mathrm{p}<0,05)$

\begin{tabular}{cc}
\hline Treatment & MDA testicular level $(\mu \mathrm{g} / \mathrm{gr})$ \\
\hline KN & $10,46 \pm 4,74^{\mathrm{a}}$ \\
KP & $23,29 \pm 11,96^{\mathrm{b}}$ \\
P1 & $14,04 \pm 6,20^{\mathrm{a}}$ \\
P2 & $13,24 \pm 10,05^{\mathrm{a}}$ \\
P3 & $11,00 \pm 5,23^{\mathrm{a}}$ \\
\hline
\end{tabular}

$\mathrm{KN} \quad=$ Negative groups who do not get any treatment

$\mathrm{KP} \quad=$ Positive group induced by alloxan

KP1 = Group Trial 1 administered with alloxan and dosage vitamin E 50 $\mathrm{iu} / \mathrm{kgbw} / \mathrm{day}$

KP2 = Group Trial 2 administered with alloxan and dosage vitamin E 100 $\mathrm{iu} / \mathrm{kgbw} / \mathrm{day}$

KP3 = Group Trial 3 administered with alloxan and dosage vitamin E 150 $\mathrm{iu} / \mathrm{kgbw} /$ day 


\title{
Pengaruh Pemberian Vitamin E terhadap Morfologi Testis Tikus Strain Wistar (Rattus novergicus) dengan Diabetes Melitus Tipe I
}

\author{
T. Ronasky ${ }^{1}$, Jufriady Ismy ${ }^{2}$ and Dasrul Dasrul ${ }^{3}$ \\ ${ }^{1}$ Program Pendidikan Dokter Spesialis Ilmu Bedah, Fakultas Kedokteran Universitas Syiah Kuala/ Rumah \\ Sakit Umum dr. Zainoel Abidin Banda Aceh. \\ ${ }^{2}$ Divisi Urologi, Departemen Bedah Fakultas Kedokteran Universitas Syiah Kuala/ Rumah Sakit Umum \\ dr. Zainoel Abidin Banda Aceh. \\ ${ }^{3}$ Staf Dosen Kedokteran Hewan, Fakultas Kedokteran Hewan Universitas Syiah Kuala/ Rumah Sakit \\ Umum dr. Zainoel Abidin Banda Aceh.
}

\begin{abstract}
Abstrak
Latar Belakang. Diabetes melitus (DM) adalah penyakit metabolik dengan karakteristik hiperglikemia yang terjadi karena kelainan sekresi insulin, kerja insulin, atau kedua-duanya. ${ }^{1}$ Penyakit ini dilaporkan terjadi pada 9\% laki-laki dan 7,9\% wanita. Laporan Center of disease control (CDC) menyebutkan tahun 2014 terdapat 8,1 juta orang tidak terdiagnosa DM dan 29,1 juta mengalami penyakit ini di Amerika Serikat. ${ }^{2}$ Pada penderita diabetes dapat terjadi kerusakan jangka panjang, disfungsi, dan kegagalan organ yang berbeda, terutama mata (diabetes retinopathy), ginjal (nefropati diabetik), saraf (neuropati diabetes), jantung (infark miokard) dan pembuluh darah (aterosklerosis) dan infertilitas. Laporan insiden infertilitas terkait DM terjadi pada $9 \%$ orang dewasa berusia $>18$ tahun mengalami akibat difungsi endokrin spermatogenesis. Vitamin E berperan sebagai antioksidan eksogen (non-enzimatis) yang dapat melindungi kerusakan membran biologis akibat radikal bebas. Vitamin E melindungi asam lemak tidak jenuh pada membran fosfolipid. Secara partikular, vitamin E juga penting dalam mencegah peroksidasi membran asam lemak tak jenuh.
\end{abstract}

Metode. Penelitian ini adalah penelitian eksperimental dengan menggunakan rancangan posttest only control group design secara laboratorium eksperimental. Rancangan penelitian ini dipilih berdasarkan konsep bahwa setiap unit dari populasi adalah homogen dan memiliki karakteristik yang sama. Pembagian sampel dilakukan secaraacak (random assignment). Pada kelompok eksperimen perlakuanlangsung diberikan stimulus dan pengamatan akhir sementara 
pada kelompok kontrol digunakan sebagai pembanding dari kelompok perlakuan.

Hasil. Rata-rata diamater tubulus seminiferus testes tikus pada masing-masing kelompok perlakuan menunjukkan angka yang bervariasi. Rata-rata diamater tubulus seminiferus testes tikus

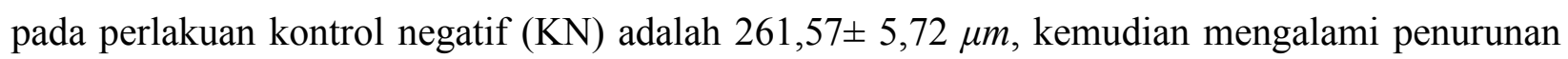
menjadi $241,18 \pm 18,53 \mu \mathrm{m}$, pada perlakuan tikus DM yang diinduksi aloksan (KP), dan mengalami peningkatan kembali pada perlakuan tikus DM yang dinduksi aloksan dan vitamin E dengan dosis $100 \mathrm{mg} / \mathrm{kgbb} /$ hari (P1), dan $200 \mathrm{mg} / \mathrm{kgbb} / \mathrm{hari}$ (P2), secara berturut-turut adalah $265,92 \pm 15,97 \mu m$ dan $271,41 \pm 24,79 \mu m$.

Kesimpulan. Berdasarkan uji statistik Analysis of variance (ANOVA) one way didapatkan nilai signifikannya p $0,039<0,05$, maka dapat ditarik kesimpulan bahwa perlakuan pemberian vitamin E (P1 dan P2) berpengaruh secara signifikan terhadap diameter tubulus seminiferus testis tikus putih diabetes.

Kata Kunci : Vitamin E, Histomorfometri Testis Tikus Putih (strain wistar), Dm Tipe 1. 


\title{
The Effect of Vitamin E Supplementation to the Morphology of Wistar Strain Rat Testis
}

\section{(Rattus Novergicus) with Diabetes Mellitus Type I}

T. Ronasky ${ }^{1}$, Jufriady Ismy ${ }^{2}$ and Dasrul Dasrul ${ }^{3}$

\begin{abstract}
Background. Diabetes mellitus (DM) is a metabolic disease with characteristics of hyperglycemia that occurs due to abnormal insulin secretion, insulin action, or both. $\underline{1}$ This disease is reported to occur in $9 \%$ of male and $7.9 \%$ of female. The Center of Disease Control (CDC) report states that there were 8.1 million undiagnosed people in 2014 and 29.1 million had this disease in the United States. $\stackrel{2}{=}$ In diabetics can occur long-term damage, dysfunction, and failure of different organs, especially the eyes (diabetic retinopathy), kidney (diabetic nephropathy), nerves (diabetic neuropathy), heart (myocardial infarction) and blood vessels (atherosclerosis) and infertility. Reports of incident DM-related infertility occur in $9 \%$ of adults $>18$ years of age experience the consequences endocrine dysfunction spermatogenesis.Vitamin E plays a role as antioxidant exogenous (non- enzymatic) which can protect damage membrane biological consequence radical free.Vitamin E protects acid fat not saturated on membrane phospholipid. In a manner particular, vitamin $\mathrm{E}$ too important in prevent peroxidation membrane acid fat not saturated.
\end{abstract}

Method. This research is experimental research with use design post-test only control group design in laboratory experimental. Design research this selected based on concept that each unit from population is homogeneous and have the same characteristics. Division sample do randomized (random assignment). On group experiment treatment immediately given stimulus and observation end while on group control used as comparison from group treatment .

Results. The average seminiferous tubule of rat testis in each treatment group showed variable numbers. The average seminiferous tubule diameters of rat testes in the negative control treatment $(\mathrm{KN})$ were $261.57 \pm 5.72 \mu \mathrm{m}$, then decreased to $241.18 \pm 18.53 \mu \mathrm{m}$, in the treatment of DM mice induced by alloxan (KP), and experienced a re-increase in the treatment of rat DM induced by alloxan and vitamin E with a dose of $100 \mathrm{mg} / \mathrm{kg} /$ day (P1), and $200 \mathrm{mg} / \mathrm{kg} /$ day (P2), respectively is $265.92 \pm 15.97 \mu m$ and $271.41 \pm 24.79 \mu m$. 
Conclusion. Based on one way Analysis of variance (ANOVA) statistical test, the significant of $p$ value was $0.039<0.05$, it can be concluded that the treatment of vitamin $\mathrm{E}$ ( $\mathrm{P} 1$ and $\mathrm{P} 2$ ) significantly affected the diameter of seminiferous tubules in testicular diabetic of white rats.

Keywords: Vitamin E, Testicular Rats Histomorphometry White (Wistar strain), Dm Type 1. 


\section{Pendahuluan}

Diabetes melitus (DM) adalah penyakit atau gangguan metabolik yang ditandai dengan peningkatan kadar glukosa di dalam darah (hyperglikemia) yang terjadi karena kurangnya sekresi dari insulin, kerja insulin, ataupun keduanya ${ }^{1,2}$. Penyakit diabetes melitus ini dilaporkan terjadi pada laki-laki sebanyak 9\% dan wanita sebanyak 7,9\% 2. Menurut International Diabetes Federation (IDF) pada tahun 2015 terdapat 415 juta orang mengalami diabetes dan diperkirakan akan meningkat mencapai 642 juta orang pada tahun 2040. ${ }^{3}$ Sedangkan di Indonesia sendiri ada 10,2 juta kasus diabetes melitus pada usia dengan rentangan 18-99 tahun dan 10 juta kasus pada rentang usia 18-79 tahun. ${ }^{4}$ Selain itu diabetes mellitus ini sangat penting, karena dapat menyebabkan komplikasi yang ditimbulkannya seperti kegagalan fungsi seksual yang menyebabkan infertilitas. ${ }^{5}$
Kegagalan fungsi seksual (disfungsi seksual) pada laki-laki sering ditemukan sebagai komplikasi diabetes mellitus lanjut. Pada lakilaki disfungsi seksual ini dapat berupa menurunnya libido dan disfungsi ereksi. ${ }^{6}$ Disfungsi ereksi pada penderita diabetes meningkat $25 \%$ di atas usia 35 tahun dan $70 \%$ sesudah usia 60 tahun, serta $30 \%$ penderita diabetes mengalami infertilitas. ${ }^{7,8}$ Konsensus pengelolaan diabetes melitus di Indonesia menyatakan prevalensi infertilitas pada penderita diabetes melitus yang diderita lebih dari 10 tahun cukup tinggi. ${ }^{8,9}$

Beberapa peneliti lain menyatakan bahwa infertilitas pada penderita diabetes mellitus juga dapat disebabkan oleh gangguan fungsi jalur hipofisis pituitary gonad, regulasi hormon testosterone yang disertai gangguan proses spermatogenesis, perubahan morfologi spermatozoa, penurunan jumlah sel Leydig, penurunan produksi dan kualitas spermatozoa. $^{10,11}$ 
Selain itu, dampak yang ditimbulkan akibat penyakit diabetes melitus, terutama pada organ testis diantaranya adalah pengecilan ukuran serta berat testis, peningkatan abnormalitas pada spermatogenesis yang ditandai dengan menurunnya jumlah sperma yang dihasilkan. ${ }^{11,12}$ Peningkatan jumlah sel yang mengalami apoptosis pada sel germinal (terutama spermatogonium dan spermatosit) dalam tubulus seminiferus telah dilaporkan juga terjadi pada hewan uji tikus diabetes. ${ }^{13,14}$

Beberapa peneliti membuktikan faktor utama pemicu terjadinya gangguan disfungsi seksual dan infertilitas pada penderita diabetes mellitus adalah akibat adanya produksi reactive oxygen spesies (ROS) yang berlebihan, sehingga terjadi ketidakseimbangan antara produksi ROS dengan kapasitas total antioksidan dalam tubuh yang dikenal dengan istilah stress oksidatif $8,15,16,17$. Stres oksidatif adalah peristiwa dimana peningkatan produksi ROS yang berupa molekul reaktif, yang muncul melalui suatu reaksi biokimiawi dari sel normal merusak membran dan mitokondria DNA, karbohidrat, protein dan lipid sel, yang selanjutnya menyebabkan berbagai gangguan fungsi tubuh diantaranya adalah organ testis ${ }^{18}$. Pada laporan studi populasi pasien dengan obesitas dan kontrol glikemik yang buruk, diperoleh pola jumlah sperma, volume testis, motilitas sperma dan morfologi juga telah dilaporkan mengalami abnormalitas. $^{9,19}$ Soudami dkk juga menjelaskan bahwa terjadi perubahan progresif struktur epididymis akibat DM dimana diameter corpus, lumen epididymis lebih kecil dibandingkan hewan coba yang tidak DM dan mendapatkan terapi insulin. ${ }^{21}$

Stres oksidatif dalam tubuh pada dasarnya dapat diatasi oleh antioksidan endogen seperti Superoksida Dismutase (SOD), Katalase (Cat) dan Glutation peroksidase (GPx) dengan cara melindungi jaringan dari kerusakan oksidatif yang disebabkan oleh senyawa oksigen reaktif. Akan tetapi jika senyawa oksigen reaktif berlebih dalam tubuh atau melebihi batas kemampuan proteksi antioksidan seluler, maka dibutuhkan antioksidan tambahan dari luar atau antioksidan eksogen, salah satunya vitamin E. ${ }^{17,22,23}$

Peranan vitamin ini sebagai antioksidan untuk infertilitas terkait disfungsi testis dan spermatozoa terjadi karena kemampuannya sebagai scavenger/ pembersih radikal bebas dengan cara menghambat peroksidase lipid sehingga berperan dalam mencegah 
berlangsungnya reaksi peroksidasi lipid yang merusak testis dan spermatogenesis. ${ }^{22}$ Dilaporkan bahwa pencegahan peroksidase lipid mampu memperbaiki fungsi testis dan meningkatkan jumlah sperma disertai penurunan persentase sperma yang berbentuk abnormal. $^{23,24}$ Pemberian vitamin E 100 $\mathrm{mg} / \mathrm{kgBB} /$ hari mampu memperbaiki kualitas spermatozoa yang diisolasi dari epididymis dan tubulus seminiferous pada model studi stres oksidatif yang di induksi arsenik. ${ }^{25}$ Namun sampai saat ini belum ada penelitian yang menjelaskan secara spesifik perubahan mikroarsitektur morfologi testis jaringan secara spesifik pada epididymis, dan tubulus seminiferous yang mendapat terapi vitamin $\mathrm{E}$ pada kondisi diabetes melitus. Berdasarkan hal tersebut telah dilakukan suatu penelitian yang bertujuan untuk megetahui pengaruh pemberian vitamin E terhadap berat testis, histomorfometri diameter dan ketebalan epitel tubulus seminiferus testis tikus strain Wistar (rattus novergicus) diabetes melitus tipe 1 .

Hasil penelitian ini diharapkan dapat meningkatkan pemahaman mengenai mekanisme infertilitas terkait diabetes melitus melalui pendekatan farmakologi. Selain itu juga untuk mengetahui manfaat darivitamin $\mathrm{E}$ terhadap kondisi testis terkait infertilitas yang dicetuskan diabetes melitus sehingga dapat menjadi pertimbangan terhadap tatalaksana dari masalah tersebut.

\section{Metode}

Penelitian dilakukan di Laboratorim Farmakologi Fakultas Kedokteran Hewan Universitas Syiah Kuala Banda Aceh selama 3 bulan yang berlangsung mulai dari 1 Februari 2018 hingga 30 April 2018

Penelitian ini merupakan penelitian eksperimental laboratoris jenis Posttest Only Control Group Design, dengan menggunakan rancangan acak lengkap (RAL) pola satu arah. Tikus dikelompokkan menjadi 4 kelompok perlakuan, masing-masing kelompok terdiri dari 6 ekor tikus. Kelompok $1(\mathrm{KN})$ yaitu tikus tidak diberi perlakuan apapun. Kelompok 2 (KP) yaitu tikus diinjeksi aloksan dosis 125 $\mathrm{mg} / \mathrm{kg}$ BB secara intraperitoneal. Kelompok 3 (P1) yaitu tikus diinjeksi aloksan dosis 125 $\mathrm{mg} / \mathrm{kg}$ BB secara intraperitoneal, kemudian diberi vitamin $\mathrm{E}$ dosis $1,0 \mathrm{mg} / \mathrm{ekor} /$ hari. Kelompok 4 (P2) yaitu tikus diinjeksi aloksan dosis $125 \mathrm{mg} / \mathrm{kg} \mathrm{BB}$, kemudian diberi vitamin E dosis 2,0 mg/ekor/hari. 


\section{Persiapan hewan percobaan}

Sebanyak 30 ekor tikus putih (Rattus Wistar) strain Wistar, berjenis kelamin jantan, berusia 3-4 bulan dengan bobot badan $250-300 \mathrm{~g}$, diperoleh dari Fakultas Kedokteran Hewan Universitas Syiah Kuala, digunakan sebagai sampel pada penelitian ini. Tikus-tikus tersebut diadaptasikan selama seminggu untuk proses aklimasi hewan percobaan dengan lingkungan. Tikus-tikus tersebut ditempatkan dalam kandang yang dirancang khusus berdinding triplek dan kawat kasa serta diperlengkapi dengan tempat air minum dan pakan. Suhu dalam kandang diatur pada suhu kamar dan dipertahankan di bawah kondisi ruang standar pada 12 jam terang / 12 jm gelap dengan suhu $25-27^{\circ}$ C. Selama masa adaptasi tikus-tikus diberi makan berupa pelet sebanyak 20 gram dan air minum diberikan secara ad libitum.

\section{Perlakuan Hewan Coba}

Pada akhir masa adaptasi masing-masing tikus ditimbang untuk mengetahui beratnya digunakan sebagai patokan awal (base line) dalam pengelompokkan tikus untuk perlakuan. Selanjutnya tikus-tikus tersebut dibagi dalam 4 kelompok perlakuan, yaitu kelompok 1 yaitu tikus normal yang tidak diberi perlakuan apapun (KN), kelompok 2 yaitu tikus yang diinjeksikan aloksan dengan dosis $120 \mathrm{mg} / \mathrm{kgbb}$ (KP). Kelompok 3 yaitu tikus yang diinjeksikan aloksan dengan dosis $120 \mathrm{mg} / \mathrm{kgbb}$ kemudian diberi vitamin $\mathrm{E}$ dengan dosis 1,00 mg/ekor/hari (P1). Kelompok 4 yaitu tikus yang diinjeksikan Aloksan dengan dosis $120 \mathrm{mg} / \mathrm{kgbb}$ kemudian diberi vitamin E dosis 2,00 mg/ekor/hari (P2). Perlakuan pemberian vitamin E dilakukan secara oral menggunakan sonde lambung selama 14 hari.

\section{Pengukuran kadar glukosa darah}

Pengukuran kadar glukosa darah tikus dilakukan menggunakan glukometer AccuCheck ${ }^{\circledR}$ Active. Kadar glukosa darah tikus diukur sebanyak 3 kali yaitu sebelum dilakukan penginduksian, setelah 7 hari penginduksian alloxan monohydrate, dan setelah pemberian terapi vitamin E selama 14 hari. Pengukuran glukosa darah dilakukan setelah tikus dipuasakan selama 12-18 jam. Pengambilan darah dilakukan melalui bagian ekor tikus. Ekor tikus dibersihkan terlebih dahulu menggunakan alkohol 70\%. Selanjutnya, digunting ujung ekor tikus hingga darah keluar dari ujung ekor tersebut. Darah yang keluar kemudian diteteskan sebanyak 1 tetes pada strip glukosa yang telah dimasukkan ke dalam glukometer dan ditunggu hingga nilai kadar glukosa darah 
$(\mathrm{mg} / \mathrm{dL})$ tertera pada layar glukometer.

\section{Pengambilan organ testis tikus putih}

Pengambilan organ testis dilakukan dengan pembedahan. Tikus di euthanasia dengan menggunakan kloroform yang dibasahkan pada kapas dan ditempatkan didalam toples.

Setelah beberapa menit tikus diambil dan diletakkan di atas papan dengan posisi dorsal recumbency. Setelah itu tikus dibedah, organ testis dicuci dengan $\mathrm{NaCl}$ fisiologis dan dimasukkan kedalam BNF 10\% selama 24 jam untuk difiksasi.

\section{Pengukuran Berat Testis}

Pengukuran berat testis dilakukan menggunakan timbangan digital, sedangkan pengukuran panjang dan diameter testis dilakukan dengan menggunakan alat ukur jangka sorong.

\section{Pembuatan preparat histologis}

Sediaan testis dalam BNF 10\% selanjutnya dilakukan proses stopping point dalam alkohol 70\% selama 24 jam, lalu dilakukan dehidrasi dengan menggunakan alkohol bertingkat yaitu $70 \%, 80 \%, 90 \%, 95 \%$ dan alkohol absolut. Jaringan kemudian dijernihkan dalam cairan xilol I (selama 1 jam), xilol II (selama 45 menit) dan xilol III (selama 45 menit). Selanjutnya jaringan diinfiltrasi dalam parafin cair dengan tiga kali ulangan yaitu, parafin cair I (selama 1 jam), parafin cair II (selama 45 menit) dan parafin cair III (selama 45 menit). Kemudian dilakukan proses penananamn (embedding) dalam parafin dam dicetak hingga menjadi blok parafin. Jaringan di dalam blok parafin disayat dengan ketebalan 4-5 mikron dan dan irisan diletakkan pada object glass untuk selanjutnya diinkubasikan untuk pembuangan paraffin, selanjutnya diwarnai dengan pewarnaan HE dan diberi perekat entelan (Kiernan, 1990). Teteskan entelan, lalu tutup dengan coverglas dan preparat siap di nilai

\section{Penilaian diameter dan ketebalan epitel tubulus seminiferus testis}

Pengukuran diameter tubulus seminiferus dan ketebalan epitel tubulus seminiferus dilakukan dengan menggunakan alat mikrometer yaitu dengan mengukur antara dua titik yang berseberangan pada garis tengahnya, titik tersebut berada pada membrana basalis tubulus seminiferus. Sedangkan ketebalan epitel tubulus seminiferus dilakukan dengan mengukur antara dinding basal tubulus sampai lumen tubulus seminiferus. Tubulus yang dipilih adalah tubulus yang memiliki penampang bulat dengan ukuran yang kurang 
lebih sama. Hasil pengukuran dinyatakan dalam satuan mikrometer $(\mu \mathrm{m})$.

\section{Analisa Data}

Data berat testis, diameter dan ketebalan epitel tubulus seminiferus pada masing-masing perlakuan dan kelompok kontrol sebelumnya dilakukan analisa normalitas dan homogenitas, jika memenuhi syarat maka dilakukan analisa sidik ragam varian (ANOVA), jika terlihat ada pengaruh maka dilanjutkan dengan uji BNT untuk menilai perbedaan antar perlakuan.

\section{Hasil}

\section{Berat testis dan pengaruh pemberian vitamin $\mathbf{E}$}

Hasil pengukuran berat testes tikus putih (Rattus norvegicus) strain Wistar pada berbagai kelompok perlakuan vitamin $\mathrm{E}$ berbagai dosis selama 14 hari ditunjukkan pada Tabel 1.

Hasil analisis of variance (ANOVA) satu arah terhadap berat testis menunjukan ada perbedaan yang nyata $(p<0,05)$. Hasil ini membuktikan bahwa perlakuan dinduksi aloksan dan pemberian vitamin $\mathrm{E}$ berpengaruh terhadap berat testis tikus putih. Selanjutnya hasil dianalisa Post Hoc dengan uji BNT didapatkan berat testis tikus diabetes yang diberi vitamin $\mathrm{E}$ dosis $200 \mathrm{mg} / \mathrm{kgbb} / \mathrm{hari}$ (P2) berbeda secara signifikan dibandingkan dengan tikus diabetes (KP) dengan nilai $\mathrm{p}=0,001$, namun tidak berbeda dibandingkan dengan tikus normal (KN) dengan nilai $\mathrm{p}=0,704$ dan pada tikus diabetes yang diberi vitamin $\mathrm{E}$ dosis 100 $\mathrm{mg} / \mathrm{kgbb} / \mathrm{hr}$ dengan nilai $\mathrm{p}=0,596$. Rata-rata berat testis tikus diabetes yang diberi vitamin $\mathrm{E}$ dosis $100 \mathrm{mg} / \mathrm{kgbb} / \mathrm{hr}$ (P1) tidak berbeda dibandingkan dengan tikus normal (KN) dengan nilai $p=0,879$. Hasil ini membuktikan bahwa pemberian vitamin $\mathrm{E}$ dapat meningkatkan berat testis tikus diabetes. Pemberian vitamin E dosis $1,0 \mathrm{mg} / \mathrm{ekor} / \mathrm{hari}$ tidak berbeda dengan dosis 2,0 mg/ekor/hari dalam meningkatkan berat testis tikus diabetes.

\section{Gambaran histologis testis tikus putih}

Hasil pengamatan gambaran histopatologis testis tikus putih normal $(\mathrm{KN})$, tikus yang diberi aloksan (KP), tikus yang diberi aloksan dan Vitamin E dosis $100 \mathrm{mg} / \mathrm{kgbb} /$ hari (P1) dan 200 $\mathrm{mg} / \mathrm{kgbb} / \mathrm{hari}$ (P2) yang diamati dengan pewarnaan HE menggunakan mikroskop cahaya dapat dilihat pada Gambar 1.

Berdasarkan fotomikrograf histopatologis diatas terlihat bahwa ada pengaruh pemberian vitamin E terhadap perubahan struktur 
histologis tubulus seminiferus testis dapat Pada kelompok tikus putih diabetes mellitus diketahui bahwa pada kelompok kontrol yang diberi vitamin $\mathrm{E}$ dosis 1,0 mg/ekor/hari negatif $(\mathrm{KN})$ yaitu kelompok tikus putih $\left(\mathrm{P}_{1}\right)$ terlihat tubulus seminiferus dengan normal yang hanya diberi olive iol membrana basalis dan tahapan perkembangan serta susunan sel spermatogeniknya ke arah lumen tubulus tampak jelas, dan padat. Lumennya terlihat penuh dengan spermatozoa. Asosiasi sel spermatogenik tersusun berlapis sesuai dengan tingkat perkembangannya dari membran basalis menuju ke arah lumen tubulus yakni spermatogonia, spermatosit, dan spermatid serta lumen tampak terisi penuh oleh spermatozoa. Hal ini menunjukan bahwa proses spermiogenesis berjalan secara normal. Pada kelompok kontrol positif (KP) yaitu tikus yang menderita diabetes terjadi kerusakan pada dinding tubulus seminiferus, walaupun spermatogonia tampak jelas berderet di lamina basalis tetapi susunan antar sel-sel spermatogeniknya renggang, tidak rapat, jumlah lapisan sel menuju lumen pendek. Lumen tampak lebar dan agak longgar, di dalamnya terdapat sel-sel spermatozoa yang berjumlah sedikit dengan ekor tampak terpisah dengan kepala, antar tubulus seminiferus saling berlekatan. Selain itu juga tampak terdapat ruang-ruang kosong pada tubulus seminiferus.

susunan sel spermatogenik yang tampak lebih jelas daripada kelompok KP, yaitu mempunyai struktur sel spermatogenik yang rapat, padat dan kompak dengan lumen yang lebih sempit berisi spermatozoa dengan struktur yang terlihat jelas berderet menuju lumen. Sel spermatogonia telihat berderet di lamina basalis, lapisan selnya lebih tinggi. Terlihat pula sel Sertoli dan sel Leydig yang nampak besar dan jelas kemungkinan terjadi peningkatan aktivitas fungsionalnya. Hal yang hampir sama juga terlihat pada kelompok perlakuan diabetes mellitus yang diberi vitamin $\mathrm{E}$ dosis 2,0 $\mathrm{mg}$ /ekor/hari $\left(\mathrm{P}_{2}\right)$ tubulus seminiferus terlihat hampir sama dengan kelompok $\mathrm{KN}$, terlihat susunan sel-sel spermatogeniknya tersusun padat, rapat dan kompak, dengan lumen yang sempit penuh sel spermatozoa. Sel spermatogonianya tampak rapat, spermatosit primernya tampak jelas, sel tampak berkelompok memadat dan besar begitu pula sel sertoli tampak jelas. Pada kelompok $\mathrm{P}_{2}$ lumen terlihat mampat dengan spermatozoa yang tampak jelas struktur kepala dan ekor yang mengarah ke lumen, hal ini berarti semakin tinggi pemberian vitamin $\mathrm{E}$ akan meningkatkan 
aktivitas spermiogenesis.

\section{Histomorfometri Diameter Tubulus Seminiferus Testis}

Diameter tubulus seminiferus merupakan garis tengah tubulus seminiferus yang bulat atau hampir bulat. Pengukuran dilakukan dengan cara menarik garis pada jarak terpendek dan terpanjang yang menghubungkan garis tepi terluar tubulus seminiferus. ${ }^{8,1}$ Hasil histomorfometri menggunakan perangkat lunak Image $J$ menunjukkan diameter tubulus seminiferus kelompok kontrol negatif $(\mathrm{KN})$, tikus diabetes (KP), tikus diabetes yang diberi vitamin $\mathrm{E}$ dosis $1,0 \mathrm{mg} / \mathrm{ekor} / \mathrm{hari}(\mathrm{P} 1)$ dan tikus diabetes (KP), tikus diabetes yang diberi vitamin $\mathrm{E}$ dosis 2,0 $\mathrm{mg} /$ ekor/hari (P2) dapat dilihat pada tabel 2 .

Tabel 2 menunjukan bahwa rata-rata diameter tubulus seminiferus testes tikus pada perlakuan kontrol negatif (KN) adalah 261,57 5,72 $\mu$ m, kemudian mengalami penurunan menjadi $241,18 \pm 18,53 \mu m$, pada perlakuan tikus DM yang diinduksi aloksan (KP), dan mengalami peningkatan kembali pada perlakuan tikus DM yang dinduksi aloksan dan vitamin E dengan dosis $100 \mathrm{mg} / \mathrm{kgbb} / \mathrm{hari}$ (P1), dan 200 $\mathrm{mg} / \mathrm{kgbb} /$ hari (P2), secara berturut-turut adalah $265,92 \pm 15,97 \mu m$ dan $271,41 \pm 24,79 \mu m$.
Hasil analisis of variance (ANOVA) satu arah terhadap diamater tubulus seminiferus testis menunjukan ada perbedaan yang nyata $(\mathrm{p}<0,05)$ diantara kelompok perlakuan. Hasil ini membuktikan bahwa perlakuan dinduksi aloksan dan pemberian vitamin $\mathrm{E}$ berpengaruh terhadap diamater tubulus seminiferus testis tikus putih. Selanjutnya hasil dianalisa Post Hoc dengan uji BNT didapatkan diamater tubulus seminiferus testis tikus diabetes yang diberi vitamin $\mathrm{E}$ dosis $200 \mathrm{mg} / \mathrm{kgbb} / \mathrm{hari}$ (P2) berbeda secara signifikan dibandingkan dengan tikus diabetes (KP) dengan nilai $\mathrm{p}=0,008$, namun tidak berbeda dengan tikus diabetes yang diberi vitamin $\mathrm{E}$ dosis 1,0 mg/ekor/hari (P1) dengan nilai $\mathrm{p}=0,346$ dan tikus normal $(\mathrm{KN})$ dengan nilai $p=0,596$. Rerata diamater tubulus seminiferus testis tikus diabetes yang diberi vitamin E 1,0 mg/ekor/hari (P1) berbeda secara signifikan dibandingkan dengan tikus diabetes (KP) dengan nilai $\mathrm{p}=0,025$ dan tikus normal (KN) dengan nilai $\mathrm{p}=0,674$. Hasil ini menunjukkan bahwa pemberian vitamin $\mathrm{E}$ dosis 1,0 mg/ekor/hari dan 2,0 mg/ekor/hari dapat meningkatkan diameter tubulus seminiferus, namun keduanya tidak berbeda dalam meningkatkan diameter tubulus seminiferus testis tikus putih diabetes. 
Histomorfometri Ketebalan Epitel Tubulus

\section{Seminiferus}

Ketebalan epitel tubulus seminiferus diukur dengan cara menarik garis dari jarak terdekat pada batas antara lapisan sel spermatogonia hingga permukaan lumen setiap tubulus seminiferus. ${ }^{11}$ Hasil pengukuran ketebalan efitel tubulus seminiferus testis tikus putih secara pengamatan histomorfometri dapat dilihat pada Gambar 2.

Fotomikrograf epitel tubulus seminiferus pada Gambar 2. menunjukkan kelompok kontrol tampak tebal dan intak pada membran basalis. Tidak terdapat celah antarsel spermatogenik. Bagian adluminal setiap tubulus seminiferus tampak banyak terdapat spermatozoa. Kelompok perlakuan diabetes menunjukkan terdapat 2 tubulus seminiferus yang epitelnya terlepas dari membran basalis. Spermatozoa pada bagian adluminal tubulus seminiferus yang tidak intak tampak lebih sedikit. Kelompok perlakuan diabetes yang diberi vitamin E dosis 1,0 mg/ekor/hari (P1) dan dosis 2,0 mg/ekor/hari (P2) menunjukkan epitel pada hampir seluruh tubulus seminiferus tidak intak antarsel spermatogenik. Spermatozoa pada bagian adluminal beberapa tubulus seminiferus tampak lebih sedikit.

Hasil histomorfometri menggunakan perangkat lunak Image $J$ menunjukkan ketebalan epitel tubulus seminiferus testis tikus Rattus norvegicus pada berbagai kelompok perlakuan yang disajikan pada tabel 3 .

Rata-rata ketebalan epitel tubulus seminiferus testis tikus pada perlakuan kontrol negatif(KN) adalah $80,93 \pm 7,33 \mu m$, kemudian mengalami penurunan menjadi $68,04 \pm 5,73 \mu \mathrm{m}$ pada perlakuan tikus DM yang diinduksi aloksan (KP), dan mengalami peningkatan kembali pada perlakuan P1 dan secara berturut-turut adalah $73,74 \pm 8,53 \mu m$ dan $85,51 \pm 4,34 \mu m$.

Hasil analisis of variance (ANOVA) satu arah terhadap diamater tubulus seminiferus testis menunjukan ada perbedaan yang nyata $(p=0,001)$ diantara kelompok perlakuan. Hasil ini membuktikan bahwa perlakuan dinduksi aloksan dan pemberian vitamin $\mathrm{E}$ berpengaruh terhadap diamater tubulus seminiferus testis tikus putih. Selanjutnya hasil dianalisa Post Hoc dengan uji BNT didapatkan diamater tubulus seminiferus testis tikus diabetes yang diberi vitamin E dosis $200 \mathrm{mg} / \mathrm{kgbb} / \mathrm{hari}$ (P2) berbeda secara signifikan dibandingkan dengan tikus diabetes $(\mathrm{KP})$ dengan nilai $\mathrm{p}=0,000$ dan tikus diabetes yang diberi vitamin $\mathrm{E}$ dosis 1,0 $\mathrm{mg} / \mathrm{ekor} /$ hari (P1) dengan nilai $\mathrm{p}=0,006$, namun tidak berbeda dengan dan tikus normal (KN) 
dengan nilai $\mathrm{p}=0,249$. Rerata ketebalan epitel tubulus seminiferus testis tikus diabetes yang diberi vitamin E 1,0 mg/ekor/hari (P1) tidak berbeda secara signifikan dibandingkan dengan tikus diabetes (KP) dengan nilai $\mathrm{p}=0,154$ dan tikus normal $(\mathrm{KN})$ dengan nilai $\mathrm{p}=0,077$. Hasil ini menunjukkan bahwa pemberian vitamin $\mathrm{E}$ dosis 2,0 mg/ekor/hari dapat meningkatkan ketebalan epitel tubulus seminiferus testis tikus putih diabetes.

\section{Pembahasan}

Penelitian mengenai pengaruh vitamin $\mathrm{E}$ terhadap berat testis, diameter tubulus seminiferus dan tebal epitel germinal tubulus seminiferus tikus putih (Rattus novergicus) strain Wistar dengan kondisi diabetes militus telah dilaksanakan. Tikus putih mengalami diabetes militus terjadi setelah mendapatkan pemberian injeksi aloksan dan ditandai dengan terjadinya peningkatan kadar glukosa dalam darah. Hasil pemeriksaan kadar glukosa darah pada penelitian ini menunjukan bahwa rata-rata kadar glukosa darah puasa kelompok tikus normal $(\mathrm{KN})$ pada penelitian ini adalah $99,40 \pm$ $12,20 \mathrm{mg} / \mathrm{dl}$. Sedangkan pada kelompok tikus putih diabetes yang diinjeksi aloksan, kadar glukosa darah mengalami peningkatan menjadi
$385,17 \pm 17,96 \mathrm{mg} / \mathrm{dl}$. Keadaan ini membuktikan bahwa penyuntikan aloksan dapat meningkatkan kadar glukosa darah, sehingga menyebabkan tikus menderita diabetes. Hal ini sesuai dengan yang dilaporkan Nur $d k k$., kadar glukosa darah tikus diabetes adalah diatas $150 \mathrm{mg} / \mathrm{dl} .{ }^{28}$ Meningkatnya kadar glukosa darah ini disebabkan karena penyuntikan aloksan, menyebabkan kerusakan atau nekrosis sel $\beta$ pankreas sehingga hormon insulin yang dihasilkan kelenjar pankreas menurun dan menimbulkan gangguan homeostasis glukosa. Dengan adanya nekrosis sel $\beta$ pankreas dan penurunan hormon insulin ini maka glukosa dalam darah tidak dapat dipergunakan oleh sel-sel organ tubuh secara sempurna, sehingga kadar glukosa darah dalam tubuh meningkat. ${ }^{29,30}$ Tingginya kadar glukosa darah mendorong lebih banyak donor elektron $\mathrm{NADH}$ dan $\mathrm{FADH}_{2}$ masuk ke dalam rantai transport elektron. Peningkatan laju transport elektron turut berkontribusi dalam pembentukan anion superoksida sehingga terjadi peningkatan reactive oxygen spesies (ROS). ${ }^{31}$ Adanya peningkatan ROS dan tidak diimbangi oleh antioksidan tubuh pada keadaan diabetes menyebabkan terjadinya suatu kondisi yang disebut stress oksidatif. ${ }^{10,12}$ Stress oksidatif tersebut akan mempengaruhi seluruh 
sel tubuh termasuk sel-sel struktural testis (sel Leydig, sel Sartoli dan sel germinal). Stress oksidatif juga menggangu keseimbangan poros hipotalamus-hipofisa-gonad yang akan mempengaruhi kerja Gonadotropin Releasing Hormone (GnRH) sehingga sekresi Follicle Stimulating Hormone (FSH) dan Luteinizing Hormonone (LH) akan terhambat. Bila kondisi ini terus belangsung akan menghambat proses spermatogenesis dan selanjutnya menyebabkan penurunan berat testis. ${ }^{13,14,15}$

Hasil penelitian ini menunjukan rerata berat testes tikus putih yang induksi aloksan (KP) adalah $0,88 \pm 0,18$ gr lebih rendah secara bermakna $(\mathrm{p}<0,05)$ dibandingkan dengan tikus norma $(\mathrm{KN})$ yaitu $1,18 \pm 0,09$ gr. Hasil ini membuktikan bahwa DM akibat induksi aloksan dapat menurunkan berat testis tikus putih, sedangkan pemberian vitamin E dapat menghambat penurunan berat testis tikus putih DM. Hasil ini sesuai dengan dilaporkan oleh beberapa peneliti bahwa pemberian induksi aloksan pada tikus putih mengakibatkan tikus menderita DM yang dikuti dengan terjadi penurunan berat testis. Hasil penelitian Aybek dkk. menunjukan bahwa tikus yang diabetes mengalami penurunan berat testis, kadar testosteron serum dan diameter epididimis secara bermakna dibandingkan dengan tikus nomal. $^{26}$ Penurunan berat testis dapat disebabkan oleh atropi, yaitu suatu proses penyusutan atau berkurang besarnya suatu organ tubuh atau jaringan dari keadaan semula atau dari bentuk normalnya ${ }^{16}$. Berkurangnya ukuran sel disebabkan oleh berkurangnya jumlah sitoplasma dan jumlah organel sitoplasma serta biasanya terkait dengan penurunan metabolisme. Pengurangan jumlah sel disebabkan oleh ketidakseimbangan proliferasi dan kematian sel dalam jangka waktu lama ${ }^{17,18}$. Selain itu menurunnya berat testis tikus putih pada tikus diabetes kemungkinan disebabkan karena induksi aloksan dapat meningkatkan produksi ROS dalam darah, yang selanjutnya dapat menyebabkan kerusakan pada sel $\beta$ pankreas dan gangguan sekresi insulin serta gangguan metabolisme glukosa dalam tubuh. ${ }^{12,15,17}$

Beberapa penelitian menunjukkan bahwa gangguan metabolisme glukosa berhubungan dengan kelebihan produksi ROS. Peningkatan ROS bila tidak mampu dinetralisir oleh enzim antioksidan tubuh dapat menyerang makro molekul sel dan dapat menyebabkan kerusakan membran sel, inti sel dan DNA mitokondria sel, yang selanjutnya terjadi apoptosis sel tubuh 
diantaranya sel-sel interstitial testis seperti sel Sartoli dan sel Leydig. Kerusakan fungsi sel Sertoli dan sel Leydig akan mengganggu proses spermatogenesis. Jika proses spermatogenesis terganggu maka akan mempengaruhi jumlah sel sel germinal yang berada dalam testis. Turunnya jumlah sel Sartoli, sel Leydig dan selsel germinal akan menyebabkan penurunan diameter tubulus seminiferus dan berat testis menjadi berkurang. ${ }^{29,30}$

Hasil penelitian ini juga membuktikan bahwa pemberian vitamin E 1,0 - 2,0 mg/kgbb/hari selama 28 hari pada tikus yang diinduksi aloksan dapat meningkatkan berat testis tikus putih yang menderita DM. Rerata berat testis tikus putih DM yang induksi aloksan (KP) adalah $0,88 \pm 0,18$ gr lebih rendah secara bermakna $(\mathrm{p}=0,001)$ dibandingkan dengan tikus putih DM yang diberi vitamin $\mathrm{E}$ dosis 1,0 $\mathrm{mg}$ /ekor/hari (P1), dan 2,0 mg/ekor/hari (P2) secara berturut-turut adalah $1,17 \pm 0,16$ gr dan $1,21 \pm 0,16$ gr. Terjadinya peningkatan berat testes ini disebabkan vitamin E mampu mencegah kerusakan akitbat peningkatan senyawa oksigen reaktif pada sel-sel Sartoli, Sel Leydig dan sel-sel spermatogenik dalam testis.
Vitamin E merupakan salah satu vitamin yang bersifat sebagai antioksidan larut dalam lemak yang mampu menghambat aktivitas senyawa oksigen reaktif dan mencegah terjadinya reaksi berantai antara senyawa oksigen reaktif dengan senyawa asam lemak tak jenuh majemuk yang terdapat pada membran plasma sel, dengan carat menyumbangkan satu hidrogen ke radikal lipid peroksil, untuk menghasilkan lipid hidroperoksida dan radikal tokoferoksil pada membran sel. Vitamin E selain bersifat sebagai antioksidan untuk mencegah terjadinya kerusakan sel akibat radikal bebas, juga mampu merangsang pertumbuhan sel-sel Sartoli dan Sel Leydig testis, serta pertumbuhan sel-sel spermatogenik dalam tubuus seminiferus testis. ${ }^{27}$ Hasil ini sesuai dengan pernyataan Chandra dkk bahwa banyaknya kandungan sel Sartoli, sel Leydig dan sel-sel spermatogenik dalam tubulus seminiferus di dalam testis juga dapat meningkatkan berat testis itu sendiri, meskipun masih ada faktor lain yang mempengaruhinya seperti jaringan ikat dan sel-sel otot polos. ${ }^{32}$

Hasil pengukuran rerata diameter tubulus seminiferus testis pada kelompok tikus putih diabetes (KP) adalah 241,18 $\pm 18,53 \mu \mathrm{m}$ lebih rendah secara bermakna dibandingkan dengan 
kelompok tikus putih normal $(\mathrm{KN})$, tikus diabetes yang induksi aloksan dan pemberian vitamin $\mathrm{E}$ dosis $1,0 \mathrm{mg} / \mathrm{ekor} / \mathrm{hari}(\mathrm{P} 1)$, dan 2,0 $\mathrm{mg}$ /ekor/hari (P2) secara berturut-turut adalah $261,57 \pm 5,72 \mu m, 265,92 \pm 15,97 \mu m$ dan 271,41 $\pm 24,79 \mu m$ (Tabel.4.6). Hasil ini menunjukkan bahwa tikus putih menderitas diabetes dapat menurunkan diameter tubulus seminiferus, sedangkan pemberian vitamin $\mathrm{E}$ dosis 1,0 $\mathrm{mg}$ /ekor/hari dan 2,0 mg/ekor/hari selama 28 hari mampu meningkatkan diameter tubulus seminiferus testis tikus putih diabetes. Menurunnya diameter tubulus seminiferus testis tikus putih diabetes yang diinduksi aloksan (KP) ini diduga karena efek sitotoksik dari aloksan, sehingga sel-sel spermatogenik yang mengisi tubulus seminiferus tidak dapat mempertahankan aktifitasnya. Dengan demikian timbul adanya perbedaan yang bervariasi pada sel-sel spermatogenik di tubulus seminiferus. Tubulus seminiferus merupakan bagian utama dari masa testis (sekitar 80\%) yang merupakan tempat berlangsungnya proses spermatogenesis. Sel-sel endokrin yang mengeluarkan hormon testosteron (sel-sel leydig) terletak dijaringan ikat antar tubulustubulus seminiferus. Sel leydig mengandung enzim yang dibutuhkan untuk sintesis testosteron. Setelah disekresikan tesstosteron yang disekresi diikat oleh ABP (Androgen Binding Protein) yang disekresikan oleh sel Sertoli masuk ke lumen tubulus seminiferus untuk proses spermatogenesis ${ }^{13,34}$. Sejalan dengan hasil penelitian sebelumnya bahwa penurunan yang terjadi pada diameter tubulus seminiferus diduga dikarenakan terhambatnya seksresi LH di hipofisis anterior yang berfungsi untuk menstimulus pertumbuhan dan jumlah sel Leydig, sehingga terjadi penurunan kadar hormon testosteron. Kurangnya kadar hormon testosteron dan FSH inilah yang diduga dapat menyebabkan atropi-atropi tubulus seminiferus $^{30,31 \text {, }}$

Hasil pengukuran rata-rata ketebalan epitel tubulus seminiferus testis pada kelompok tikus putih diabetes (KP) lebih rendah dibandingkan dengan kelompok tikus putih normal $(\mathrm{KN})$. Hasil pengamatan histopatologi menunjukkan bagian adluminal pada kelompok tikus normal (KN) tampak sel spermatozoa yang lebih banyak pada setiap tubulus seminiferus dibandingkan dengan kelompok tikus diabetes (KP). Epitel tubulus seminiferus pada kelompok tikus putih normal $(\mathrm{KN})$ lebih intak antar sel spermatogenik maupun antara 
membran basalis dengan sel spermatogenik. Sel spermatogenik yang tidak intak antarselnya maupun dengan membran basalis menyebabkan hasil pengukuran histomorfometri ketebalan epitel tubulus seminiferus pada kelompok tikus putih diabetes (KP) lebih rendah dibandingkan kelompok tikus putih normal (KN). Hasil penelitian ini menunjukkan stres oksidatif akibat diabetes berefek terhadap ketebalan epitel dan diameter tubulus seminiferus. Pembatasan kalori tingkat rendah pada diabetes mengakibatkan atrofi tubulus seminiferus dan penurunan diameter tubulus seminiferus. ${ }^{37} \mathrm{Hal}$ tersebut terjadi karena adanya penurunan jumlah sel spermatosit dan sel spermatid yang mengisi epitel tubulus seminiferus. ${ }^{35}$ Pembatasan akses terhadap nutrisi dapat menurunkan ketebalan epitel dan diameter tubulus seminiferus testis. Kurangnya asupan protein menunjukkan seluruh tubulus seminiferus pada kelompok tikus diabetes (KP) memiliki lumen yang luas dan epitel yang tipis dibandingkan dengan tikus normal (KN). Hal ini terjadi karena protein sangat penting dalam mengangkut testosteron masuk ke dalam lumen tubulus seminiferus untuk berlangsungnya spermatogenesis sehingga menghambat maturasi, pertumbuhan dan fungsi organ reproduksi. ${ }^{14,15,16}$
Tubulus seminiferus terdiri dari sel spermatogenik dan sel sertoli. Sel sertoli berfungsi sebagai penunjang, diantaranya menjaga ikatan antarsel sertoli, dengan sel spermatogenik, atau antarsel spermatogenik untuk membentuk sawar darah testis. ${ }^{15,16}$ Sawar darah testis berfungsi meregulasi nutrisi dan faktor pertumbuhan untuk perkembangan sel spermatogenik. Tampak pada fotomikrograf tubulus seminiferus, epitel pada kelompok diabetes tidak intak satu sama lain. ${ }^{32} \mathrm{Hal}$ ini disebabkan karena stres oksidatif merusak taut dan adesi antarsel Sertoli, sel Sertoli dengan sel spermatogenik dan antar sel spermatogenik. Mekanisme yang terjadi adalah melalui aktivasi sinyal phosphatidylinositol 3-kinase (PI3K)focal adhesion kinase (FAK). Phosphatidylinositol 3-kinase yang semula terdapat pada sitosol mengalami translokasi menuju membran sel yang akan meningkatkan permeabilitas membran sel epitel dan sel endotel. Focal adhesion kinase berperan sebagai mediator dalam proses ini. Selain itu, dikarenakan taut antar sel sertoli rusak, maka terjadi kekurangan nutrisi dan faktor pertumbuhan bagi perkembangan sel spermatogenik. ${ }^{23,33}$ Berkurangnya spermatozoa pada bagian adluminal tubulus seminiferus terjadi karena penurunan glukosa dalam tubuh. 
Hal ini mengubah aksis kelenjar hipotalamushipofisis-testis yang menurunkan spermatogenesis. 35,36 Akibatnya, terjadi penurunan berat testis. ${ }^{38}$ Perubahan berat testis dapat merefleksikan perubahan pada tubulus seminiferus yang mengisi $80 \%$ massa testis. ${ }^{39,40}$

\section{Kesimpulan}

Berdasarkan hasil analisis dan pembahasan yang telah diuraikan oleh peneliti, dapat diambil kesimpulan beberapa hal sebagai berikut:

1. Pemberian vitamin $\mathrm{E}$ berpengaruh terhadap perbaikan berat testis tikus strain Wistar (rattus novergicus) diabetes melitus tipe 1 .

2. Pemberian vitamin $\mathrm{E}$ berpengaruh terhadap perbaikan perubahan histomorfometri diameter dan ketebalan epitel tubulus seminiferus testis tikus strain Wistar (rattus novergicus) diabetes melitus tipe 1 .

\section{Saran}

1. Diperlukan penelitian lebih lanjut mengenai peran vitamin $\mathrm{E}$ terhadap spermatogenesis tikus putih diabetes militus.
2. Diperlukan penelitian lebih lanjut mengenai peran vitamin $\mathrm{E}$ terhadap biomarker lain yang terkait dengan stress oksidatif dan infertilitas seperti kadar MDA dan aktivitas SOD, Katalase dan Glutation Peroksidase jaringan testis 


\section{Daftar Referensi}

1. Soviana, E., Banundari, R., dan Nyoman, S. W. Pengaruh Suplementasi $\beta$-carotene Terhadap Kadar Glukosa Darah dan Kadar Malondialdehida pada Tikus Sprague dawley yang Diinduksi Streptozotocin. Jurnal Gizi Indonesia 2014;2(2): 41-46.

2. American Diabetes Association. Standards of medical care in diabetes2015. Diabetes Care 38: 1-94

3. International Diabetes Federation. 2015. Diabetes Atlas [serial online] http://www.idf.org/idf-diabetes-atlasseventh-edition. 24 Oktober 2018

4. World Health Organization (WHO). [updated 2017; cited 2017 July 11]. Tersedia fromhttp://www. who.int/topics/diabetes_mellitus/en/.

5. Enzlin P, Mathieu C, Van den Bruel A, Vanderschueren D, Demyttenaere K. Prevalence and Predictors of Sexual Dysfunction in Patients with Type 1 Diabettes . Belgium. Available from : URL :http://www.care. diabetesjournals. org/cgi/content/full/26/2/409; 2003.
6. Russel, S.T., B.K. Khandheria, A. Nehra. Erectile Dysfunction and Cardiovaskular Disease. Rochester Min6 (18 screens). Available from URL http://peereviewedjournal/mayoclinic Proceding. 2004. html

7. Sukawan, U.Y. Gangguan Seksual pada Pria Penderita Diabetes Mellitus. dalam Pertemuan Ilmiah tahunan XIV Perkumpulan Andrologi Indonesia dan Kongres Nasional I Asosiasi Sexolog Indonesia. Buku Acara dan Kumpulan Abstrak. Denpasar. p 15713. 2002.

8. Amaral, S., Oliveira, P. J., and Ramalho, J. Diabetes and the Impairment of Reproductive Function: Possible Role of Mitochondria and Reactive Oxygen Species. Current Diabetes Reviews 2008; 4(1): 46-54.

9. PERKEMI. Konsensus Pengelolaan Diabetes Melitus Tipe 2 di Indonesia 2002. Semarang. 2002; p 6-7.

10. Amaral, S., Moreno, A. J., Santos, M. S., Seica, R., and Santos, J. R. Effects of Hyperglycemia on Sperm and Testicular Cells of Goto-Kakizaki and 
Streptozotocin-Treated Rat Models for Diabetes. Theriogenology 2006; 66: 2056-2067.

11. Jameel Gulab Jargar, Saeed Yendigeri, Salim Abbasali Dhundasi, Kusal Kanti Das. Protective effect of Vitamin E ( $\alpha$-tocopherol) on nickel-induced alteration of testicular pathophysiology in alloxan-treated diabetic rats. International Journal of Clinical and Experimental Physiology| Oct-Dec 2014 | Vol 1 | pp. 290-296

12. Abd El-Rahim, A. H.; Radwan, H. A.; Abd El-Moneim, O. M.; Farag, I. M. The influence of amaryl on genetic alterations and sperm abnormalities of rats with alloxan-induced hyperglycemia. Journal of American Science, 2010. 6(12):1739-1748.

13. Ballester, J., Munoz, M.C., Dominguez, J., Rigau, T., Guinovart, J.J. and Rodriguez-Gil, J.E. Insulin Dependent Diabetes Affects Testicular Fuction by FSH and LH-Link Mehanism. $J$ Androl. . 2004. 25(5) : 706-719.

14. Basmatzou, T. Diabetes Melitus and Influences on Human Fertility.
International Journal of Caring Sciences. 2016. 9(1) : 371-379.

15. Agarwal A, Cocuzza M, Abdelrazik H, Sharma RK. Oxidative stress measurement in patients with male or female factor infertility. Handbook of Chemiluminescent Methods in Oxidative Stress Assessment. 2008. p. 195-218.

16. Maslachah, L., Sugihartuti, R., dan Kurniasanti, R. Hambatan Produksi Reactive Oxygen Species Radikal Superoksida (O2-) oleh Antioksidan Vitamin E ( $\alpha$-Tocopherol) pada TIkus Putih (Rattus norvegicus) yang Menerima Stressor Renjatan Listrik. Media Kedokteran Hewan. 2008; 24(1): 21-26.

17. Darmawan H. Production of ROS and Its Effects on Mitochondrial and Nuclear DNA, Human Spermatozoa, and Sperm Function. Medical Journal Indonesia. 2007.; 16: 2.

18. Adelati, S., Juniarto, A.Z. dan Miranti, I.K. $2016 . \quad$ Histopatologi Spermatogenesis Testis Tikus Wistar Diabetes Melitus. J.K.D. 5(4) : 17601769 
19. Kanter, M., Aktas, C., and Erboga, M. 2012. Protective Affects of Quercetin Against Apoptosis and Oxidative Stress in Streptozotocin-Induced Diabetic Rat Testis. Food Chem Toxicol 50: 719725.

20. Tiwari BK, Pandey KB, Abidi AB, Rizvi SI. Marker oxidative stress during diabetes mellitus. Journal of biomarkers Volume 2013 : 378, 790, p1-8.

21. Soudamani S, Malini T, Balasubramanian K. Effects of Streptozotocin-Diabetes and Insulin Replacement on the Epididymis of Prepubertal Rats: Histological and Histomorphometric Studies. Endocrine Research. 2005;31(2):81-98.

22. Agarwal, A., Virk, G., Ong, C. dan Plessis, S. S.D. Effect of Oxidative Stress on Male Reproduction. World $J$ Mens Health, 2014; 32 (1): 1-17.

23. Setiawan B, Suhartono E. Stres Oksidatif dan Peran Antioksidan pada Diabetes Melitus. Majalah Kedokteran Indonesia Pebruari. 2005;55(2).
24. Suarsana IN, I.H. Utama, I.G. Agung dan A. Suartini. 2011. Pengaruh hiperglikemia dan vitamin E pada kadar malonaldehida dan enzim antioksidan intrasel jaringan pankreatikus. Majalah Kedokteran Bandung 43(2):72-6.

25. Haidara MA, Mikhailidis DP, Rateb MA, Ahmed ZA, Yassin HZ, Ibrahim IM, et al. Evaluation of the effect of oxidative stress and vitamin $\mathrm{E}$ supplementation on renal function in rats with streptozotocin-induced Type 1 diabetes. Journal of Diabetes and its Complications. 2009;23(2):130-6

26. Aybek H, Aybek Z, Rota S, Sen N, Akbulut M. The effects of diabetes mellitus, age, and vitamin $\mathrm{E}$ on testicular oxidative stress. Fertil Steril. 2008 Sep; 90(3):755-60. PMID: 17482598

27. Keskes-Ammar L, Feki chakroun N, Rebat T, et al. Sperm Oxidative Stress and the Effect of an Oral Vitamin E and Selenium Supplement on Semen Quality in Infertile Men. Syst Biol Reprod Med. 2003;49(2):83-94. doi: $10.1080 / 01485010390129269$. 
28. Nur, S.M., Awaloei, H. dan Wuisan, J. Uji efek air perasan albedo semangka kuning (Citrilus lanatus (Thunb.) Matsum. \& Nakai) terhadap kadar glukosa darah pada tikus wistar (Rattus norvegicus) yang diinduksi aloksan. Jurnal e-Biomedik (eBm). 2016. 4(1): 17.

29. Coskun O, Ocakci Ayse, Bayraktaroglu $\mathrm{T}$, and Kanter M. Exercise Training Prevents and Protects StreptozotocinInduced Oxidative Stress and B-Cell Damage in Rat Pancreas. Departement of Medical Histology and Embryology. Turkey: Zonguldak Karaelmas University. 2004

30. Maneesh,M., Jayalaksmi, H., Singh, T.A. dan Cakrabhati, A. Impaired Hipothalami-Pituitary-Gonadal axist function in men with diabetes melitus. Indian Journal of Clinichal Biochemistry. 2006. 21(1):165-166.

31. Mitayani. 2009. Pengaruh Pemberian Ekstrak Pare (Momordica charantia L) Terhadap Jumlah Spermatozoa, Diameter Tubulus Seminiferus dan Berat Testis Tikus Jantan Strain
Wistar Sebagai Bahan Kontrasepsi Alamiah. Tesis Unpad

32. Apriliani, M., Nurcahayani, N. dan Busman, H.Efek Pemaparan Kebisingan terhadap Jumlah Selsel Spermatogenik dan Diameter Tubulus Seminiferus Mencit (Mus musculus L.). Lembaga Penelitian Universitas Lampung. 2013.

33. Sulistyoningrum, E., Setiawati., Nindyastuti, H. dan Putra, A.N. Infusa Daging Buah Mahkota Dewa Memperbaiki Kerusakan Testis dan Parameter Sperma Tikus Diabetik. Jurnal Sains Medika, 2012; 4 (2): 115123.

34. Abdulgani, N dan Maharani, L. Potensi Regenerasi Sel Leydig dan Sel Spermatogenik pada Testis Mencit Mencit (Musmusculus) Hiperglikemik yang Diinduksi dengan Ekstrak IkanGabus (Channa striata). Tugas Akhir. Surabaya: ITS.2014.

35. Fatani, A. J., Al-Rejale, S., Abuohashish, H. M., Al-Assaf, A., Parmar, M. Y., and Ahmed, M. M. 2015. Lutein Dietary Supplementation Attenuates 
Streptozotocin-induced Testiscular

Damage and Oxidative Stress in

Diabetic Rats. BMC Complementary and Alternative Medicine 15:204

36. Kianifard D, Sadrkhanlou RA, Hasanzadeh S. The ultrastructural changes of the sertoli and leydig cells following streptozotocin induced diabetes. Iran J Basic Med Sci 2012;15:623-35.

37. Sanguinetti RE, Ogawa K, Kurohmaru M, Hayashi Y. Ultrastructural changes in mouse Leydig cells after streptozotocin administration. Exp Anim 1995;44:71-3.

38. Oztürk F, Gül M, Agkadir M, Yagmurca M. Histological alterations of rat testes in experimental diabetes. $\mathrm{T}$ Kin J Med Sci 2002;22:173-8.

39. Palmeira, C. M., Santos, D. L., Seica, R., Moreno, A. J., andSantos, M. S. Enhanced Mitochondrial Testicular Antioxidant Capacity in Goto-Kakizaki Diabetic Rats: Role of Coenzyme Q. Am J Physiol Cell Physiol. 2001: 281: 1023-1028.

40. Shayakhmetova, G. M., Bondarenko, L. B., and Kovalenko, V.M. Damage of Testicular Cell Macromolecules and Reproductive Capacity of Male Rats Following Co-Administration of Ethambutol, Rifampicin, Isoniazid Acid and Pyrazinamide. Interdiscip Toxicol, 2012:5(1): 9-14. 
Tabel 1. Data rataan ( $\pm \mathrm{SD})$ berat testis tikus Rattus norvegicus

\begin{tabular}{ccc}
\hline Perlakuan & Ulangan & Rataan Berat Testis (mg) \\
\hline KN & 5 & $1,18 \pm 0,09^{\mathrm{a}}$ \\
KP & 5 & $0,88 \pm 0,18^{\mathrm{b}}$ \\
P1 & 5 & $1,17 \pm 0,16^{\mathrm{a}}$ \\
P2 & 5 & $1,21 \pm 0,16^{\mathrm{a}}$ \\
\hline
\end{tabular}

Ket: Superskrip yang berbeda pada kolom yang sama menunjukan perbedaan yang nyata $(\mathrm{P}<0.05)$.

$\mathrm{KN}=$ Kelompok tikus normal yang tidak mendapatkan perlakuan

$\mathrm{KP}=$ Kelompok tikus putih diebets

$\mathrm{P} 1=$ Kelompok tikus putih diabetes yang diberi vitamin E 1,0 mg/ekor/hari

P2 = Kelompok tikus putih diabetes yang diberi vitamin E 2,0 mg/ekor/hari
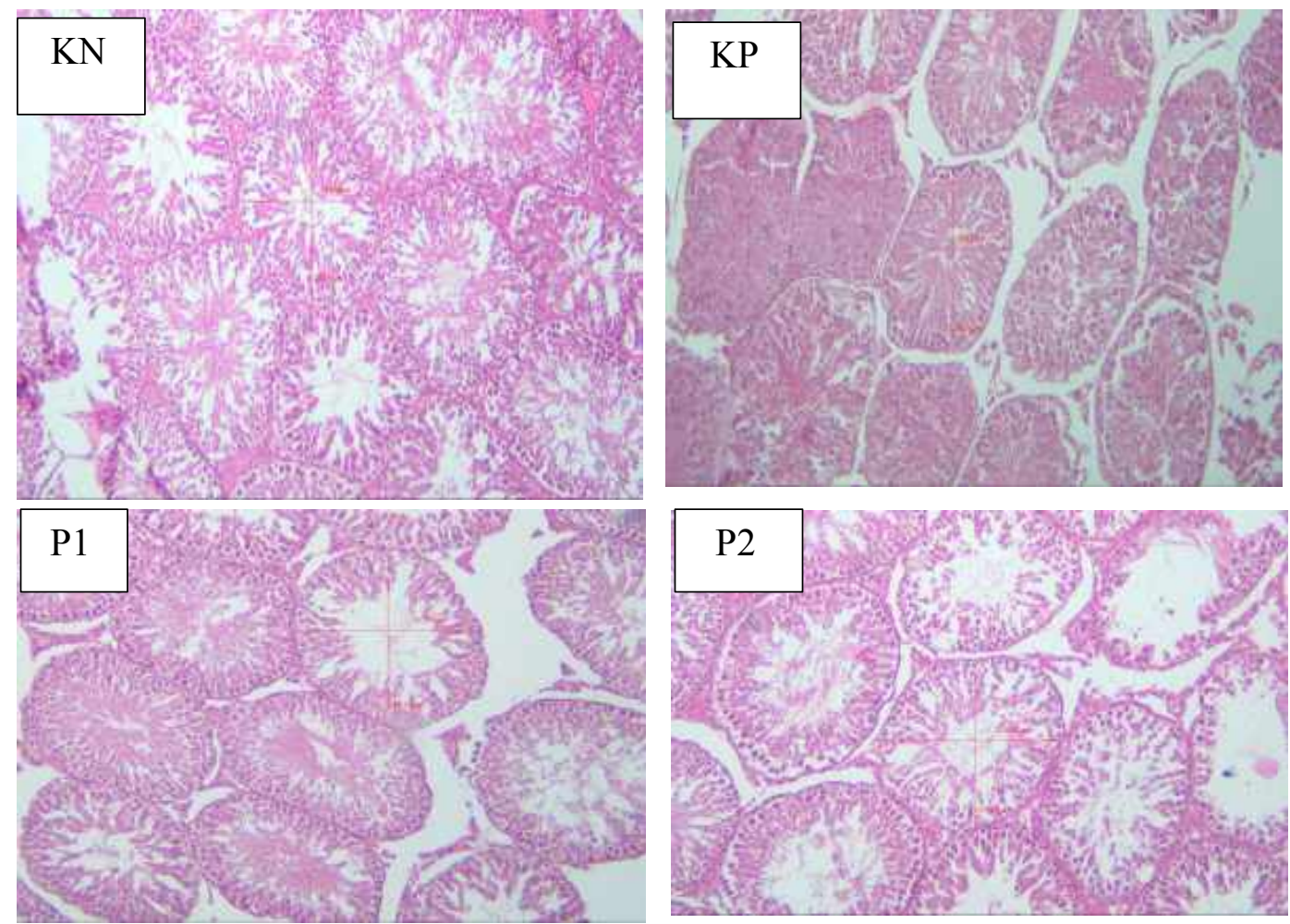

Gambar 1 Fotomikrograf histopatologis testis tikus putih strain Wistar pada kontrol Negatif (KN),

Kontrol Positif (KP), Perlakuan 1 (P1) dan Perlakuan 2 (P2) dengan pewarnaan HE dan pembesaran 40x. 
Tabel 2 Data rataan ( \pm SD) diamater tubulus seminiferus testes tikus Rattus norvegicus

\begin{tabular}{ccc}
\hline Perlakuan & Ulangan & $\begin{array}{c}\text { Diamater tubulus } \\
\text { seminiferus Testis }(\boldsymbol{\mu m})\end{array}$ \\
\hline KN & 5 & $261,57 \pm 5,72$ \\
KP & 5 & $241,18 \pm 18,53$ \\
P1 & 5 & $265,92 \pm 15,97$ \\
P2 & 5 & $271,41 \pm 24,79$ \\
\hline
\end{tabular}

Ket: Superskrip yang berbeda pada kolom yang sama menunjukan perbedaan yang nyata $(\mathrm{P}<0.05)$.

$\mathrm{KN}=$ Kelompok tikus normal yang tidak mendapatkan perlakuan

$\mathrm{KP}=$ Kelompok tikus putih diebets

P1 = Kelompok tikus putih diabetes yang diberi vitamin E 1,0 mg/ekor/hari

P2 = Kelompok tikus putih diabetes yang diberi vitamin E 2,0 mg/ekor/hari
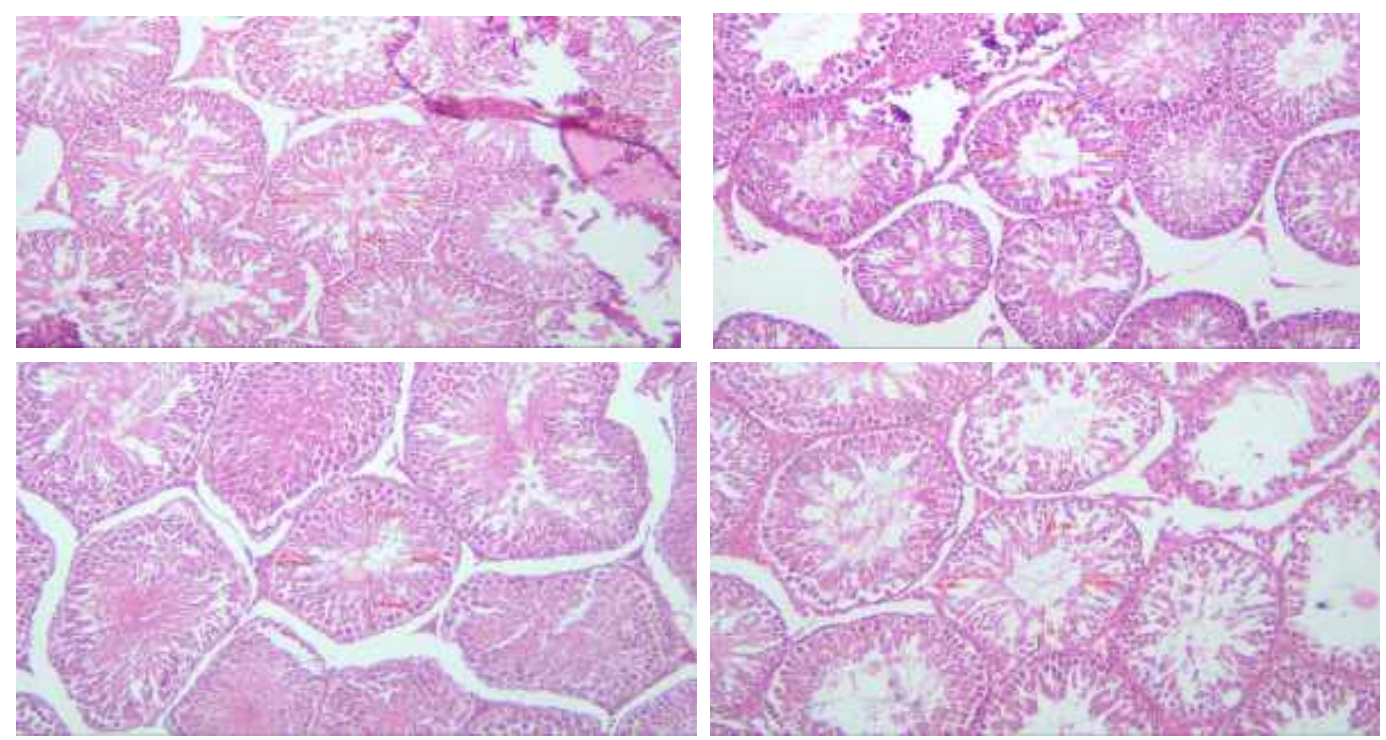

Gambar 2. Fotomikrograf histomorfometri ketebalan epitel tubulus seminiferus testis tikus putih strain Wistar pada Perlakuan Kontrol Negatif(KN), Kontrol Positif(KP), Perlakuan Vit. E 1,0 mg/ekor/hari (P1) dan Perlakuan Vit. E 2,0 mg/ekor/hari (P2) dengan pewarnaan HE pada pembesaran 40x 
Tabel 3. Data rataan $( \pm \mathrm{SD})$ ketebalan epitel tubulus seminiferus testes tikus Rattus norvegicus

\begin{tabular}{ccc}
\hline Perlakuan & Ulangan & $\begin{array}{c}\text { ketebalan epitel tubulus } \\
\text { seminiferus }(\boldsymbol{\mu m})\end{array}$ \\
\hline KN & $\mathbf{5}$ & $80,93 \pm 7,33$ \\
KP & $\mathbf{5}$ & $68,04 \pm 5,73$ \\
P1 & $\mathbf{5}$ & $73,74 \pm 8,53$ \\
P2 & $\mathbf{5}$ & $85,51 \pm 4,34$ \\
\hline
\end{tabular}

Ket: Superskrip yang berbeda pada kolom yang sama menunjukan perbedaan yang nyata $(\mathrm{P}<0.05)$.

$\mathrm{KN}=$ Kelompok tikus normal yang tidak mendapatkan perlakuan

$\mathrm{KP}=$ Kelompok tikus putih diebets

P1 = Kelompok tikus putih diabetes yang diberi vitamin E 1,0 mg/ekor/hari

P2 = Kelompok tikus putih diabetes yang diberi vitamin E 2,0 mg/ekor/hari 


\title{
Intervensi Endovaskular Aneurisma Aorta Torako-Abdominalis Pada Pasien dengan Sindrom Marfan: Tinjauan Literatur
}

\author{
Patrianef Darwis $^{1}$, Yoni Vanto ${ }^{2}$ \\ ${ }^{1}$ Departemen Ilmu Bedah, Fakultas Kedokteran Universitas Indonesia, Rumah Sakit Umum Pusat \\ Rujukan Nasional Cipto Mangunkusumo \\ ${ }^{2}$ Peserta Program Pendidikan Ilmu Bedah, Fakultas Kedokteran Universitas Indonesia, Rumah Sakit \\ Umum Pusat Rujukan Nasional Cipto Mangunkusumo
}

\begin{abstract}
Abstrak
Latar Belakang. Sindroma Marfan merupakan penyakit jaringan ikat yang diturunkan secara autosom dominan dengan penyebab utama morbiditas dan mortalitas akibat kelainan aorta. Bedah terbuka merupakan tata laksana utama untuk kelainan aorta pada pasien sindrom Marfan, namun tidak semua pasien dapat dilakukan bedah terbuka, misalkan pada kondisi hemodinamik yang tidak stabil dan usia tua. Intervensi endovaskular merupakan salah satu pendekatan tata laksana minimal invasif yang masih kontroversial karena adanya risiko kegagalan primer berupa kebocoran aneurisma.
\end{abstract}

Metode. Penelusuran literatur dilakukan secara daring pada 3 database: PubMed, ClinicalKey, dan ScienceDirect. Dilakukan pemilihan studi berdasarkan kriteria inklusi dan eksklusi literatur. Artikel terpilih ditelaah secara kritis berdasarkan alur seleksi dari PRISMA Flow Diagram. Didapatkan 6 artikel yang ditelaah secara kritis

Hasil. Tiga literatur mengenai prosedur endovaskular menunjukkan angka keberhasilan prosedur berkisar 20\%-38\% dengan risiko kegagalan primer (primary endoleak) yang cukup tinggi. Kematian akibat aneurisma lebih tinggi pada pasien sindrom Marfan yang menjalani teknik endovaskular dibandingkan pasien yang dilakukan bedah terbuka.

Kesimpulan. Prosedur endovaskular dapat dijadikan alternatif tatalaksana dengan mempertimbangkan kondisi pasien. Sedikitnya jumlah subyek pada penelitian-penelitian yang ada serta waktu follow-up yang singkat menyebabkan efektivitas teknik endovaskular masih diragukan jika dibandingkan dengan prosedur bedah terbuka.

Kata kunci: sindrom marfan, endovaskular, bedah terbuka, aneurisma aorta, torako-abdominal 


\section{Latar Belakang}

Berdasarkan data rekam medis di Rumah Sakit Cipto Mangunkusumo terdapat 11 kasus dan Pusat Jantung Nasional Harapan Kita terdapat 39 kasus sindrom Marfan dalam kurun waktu 2006-2012. ${ }^{1} \quad$ Sedangkan secara global prevalensi sindrom Marfan adalah sekitar 2-3 per 10.000 penduduk, dan diperkirakan terdapat sekitar 25\%-30\% mutasi baru. ${ }^{1}$ Mutasi gen pembentuk jaringan ikat pada pasien sindrom Marfan dapat menimbulkan manifestasi klinis berupa kelainan pada mata, muskuloskeletal, maupun sistem kardiovaskular. Namun penyebab utama morbiditas dan mortalitas pada pasien dengan sindrom Marfan adalah kelainan pada aorta. Pada pasien dengan sindrom Marfan aorta akan mengalami dilatasi, aneurisma, dan diseksi sehingga menyebabkan rendahnya angka harapan hidup pasien dengan sindrom Marfan. Bedah terbuka merupakan tata laksana utama untuk kelainan aorta pada pasien dengan sindrom Marfan. ${ }^{1,2}$
Bedah aorta elektif memiliki tingkat mortalitas sebesar 1,5\% pada rumah sakit yang berpengalaman, namun tingkat mortalitas ini dapat mencapai 11,7\% jika dilakukan dalam kondisi gawat darurat. Komplikasi yang dapat terjadi antara lain ialah paraplegia dan gagal ginjal akibat gangguan perfusi. Selain itu pasien yang telah menjalani prosedur bedah terbuka juga berisiko untuk mengalami diseksi, aneurisma, maupun ruptur aorta berulang sehingga memerlukan intervensi bedah berulang. 3,4

Tidak semua pasien aneurisma aorta pada sindrom marfan dapat dilakukan bedah terbuka misalnya pada hemodinamik tidak stabil dan usia tua. Intervensi endovaskular merupakan salah satu pendekatan tata laksana minimal invasif bagi pasien dengan sindrom Marfan yang mengalami aneurisma aorta.

Correspondents:

Patrianef Darwis

Divisi Bedah Vaskular dan Endovaskular

Departemen Ilmu Bedah Fakultas Kedokteran Universitas

Indonesia Rumah Sakit Cipto Mangunkusumo

email : patrianef@gmail.com 
Intervensi ini dilakukan dengan memasukkan stent graft yang dilakukan di suatu laboratorium kateterisasi dengan kondisi pasien yang dibius umum.

Saat ini sudah banyak dokter bedah yang melakukan teknik endovaskular bagi pasien aneurisma aorta karena pertimbangan keamanan dan tingkat keberhasilan yang cukup baik. Pendekatan ini dapat dijadikan suatu tata laksana life-saving bagi pasien yang tidak dapat dilakukan prosedur bedah terbuka. Meskipun demikian tata laksana endovaskular memiliki risiko komplikasi yang masih kontroversial karena adanya risiko kegagalan primer berupa kebocoran aneurisma dan membutuhkan tindakan bedah terbuka. Telah literatur ini dibuat karena sedikitnya kasus sindrom Marfan di seluruh dunia dengan tujuan agar diketahui kelebihan dan kekurangan penggunaan tata laksana endovaskular bagi pasien sindrom Marfan yang mengalami kelainan pada aorta torako-abdominalis. ${ }^{4,5}$

\section{Pertanyaan Penelitian}

Pertanyaan penelitian pada studi ini adalah bagaimana efektivitas teknik endovaskular sebagai tata laksana pilihan pada pasien sindrom Marfan yang mengalami aneurisma aorta torako-abdominalis?
Dengan rincian sebagai berikut:

Patient : Pasien sindrom Marfan dengan aneurisma aorta torako-abdominalis Intervension : Intervensi endovaskular

Comparison : Bedah terbuka

Outcome : Tidak adanya kebocoran aneurisma dan tidak memerlukan prosedur bedah terbuka

\section{Metode}

Penelitian dilakukan di Departemen Ilmu Bedah FKUI-RSCM, Divisi Bedah Vaskular pada April 2019. Penelusuran literatur dilakukan dengan menggunakan sumber pangkalan data yaitu PubMed, ClinicalKey, dan ScienceDirect. Pencarian menggunakan kata kunci "Marfan syndrome", "open surgery", "endovascular surgery", "aortic aneurysm", and "torakoabdominal"

Dilakukan pemilihan studi berdasarkan kriteria inklusi dan eksklusi literatur. Kriteria inklusi untuk pencarian literatur yang digunakan adalah (1) Tersedia dalam bentuk full-text (2) Menggunakan bahasa Inggris (3) Studi pada pasien sindrom Marfan dengan aneurisma aorta. Kriteria Eksklusi yang digunakan adalah (1) Publikasi dalam bentuk korespondensi, 
editorial, maupun commentary (2) Tidak Pembahasan

menyebutkan luaran berupa keberhasilan tindakan, morbiditas pascaoperasi, dan

Sindrom Marfan merupakan suatu penyakit mortalitas (3) Aneurisma selain pada aorta (4) jaringan ikat dengan penyebab kematian utama Subyek selain manusia (5) Prosedur hibrid yaitu diseksi/aneurisma aorta. Prosedur bedah (kombinasi bedah terbuka dan bedah terbuka merupakan tata laksana standar bagi endovaskular).

pasien sindrom Marfan yang mengalami aneurisma pada aorta torako-abdominalis. Dilakukan penilaian terhadap studi yang Prosedur bedah terbuka diindikasikan bagi terpilih, dengan melihat karakteristik subjek, pasien berusia muda, kondisi hemodinamik tahun studi, tempat studi dan hasil dari masing- baik, dan gambaran anatomi aorta tertentu masing studi. Alur seleksi mengikuti PRISMA (highly angulated aortic neck) yang Flow Diagram.

membutuhkan intervensi berulang. ${ }^{11}$ Luaran bedah terbuka untuk aneurisma aorta torako-

\section{Hasil}

Setelah dilakukan pencarian literatur sesuai alur abdominalis pada pasien sindrom Marfan cukup pencarian, didapatkan 32 jurnal dengan naskah lengkap. Sebanyak 26 jurnal dieksklusi karena berupa telaah literatur, mengikutsertakan subyek selain sindrom Marfan, aneurisma bukan pada aorta torako-abdominalis dan tidak mencantumkan luaran hasil tindakan. Didapatkan 6 jurnal yang relevan sesuai kriteria inklusi dan eksklusi. Hasil rangkuman jurnal dicantumkan dalam rangkuman studi pada tabel 4.1. Hasil telaah kritis terhadap jurnal dicantumkan pada tabel 4.2.

baik yaitu 0\%-7\% kematian intra-operasi, 0\%5\% angka kejadian stroke, 0\%-13\% angka kejadian gagal ginjal, dan paraplegia sebesar 0\%-7\%. Luaran yang baik ini disebabkan oleh usia pasien yang relatif muda ketika dilakukan tindakan bedah terbuka serta rendahnya angka prevalensi pasien sindrom Marfan dengan komorbid yang diikutsertakan pada penelitian tersebut. ${ }^{10}$

Penelitian menunjukkan bahwa laju pembedahan ulang pada pasien sindrom Marfan sebesar 27\% dengan tingkat kematian mencapai $31 \%$ pada pembedahan ulang. Penelitian oleh 
Gott dkk menunjukkan bahwa risiko kematian pasca pembedahan ulang dalam kurun waktu 60 hari setelah pembedahan adalah $5 x$ lebih besar dibandingkan pasien yang tidak menjalani pembedahan ulang. ${ }^{13}$ Selain risiko mortalitas yang tinggi pada bedah terbuka berulang, pasien sindrom Marfan yang telah lanjut usia dengan berbagai komorbiditas bukan merupakan kandidat yang tepat untuk dilakukan pembedahan. ${ }^{7,8}$

Berbagai studi observasi dan meta analisis menunjukkan bahwa prosedur bedah terbuka memiliki tingkat morbiditas peri-operatif dan mortalitas yang lebih tinggi dibandingkan teknik endovaskular terutama bagi pasien yang berusia lebih tua dengan kondisi hemodinamik yang buruk. Teknik endovaskular hadir sebagai alternatif bagi pasien yang tidak memungkinkan untuk dilakukan prosedur bedah terbuka. Dari ketiga literatur yang dianalisis diketahui bahwa keberhasilan prosedur cukup baik yaitu berkisar 20\%-38\%. Penelitian oleh Mercheix dkk (2008) juga menunjukkan bahwa prosedur ini memiliki risiko komplikasi yang rendah dan ditandai dengan tidak adanya pasien yang mengalami paraplegia, hal ini menunjukkan bahwa pendekatan endovaskular berhasil mempertahankan integritas aorta. ${ }^{9,11}$
Meskipun memiliki efektivitas yang cukup baik dan dapat dijadikan sebagai alternatif selain prosedur bedah terbuka, pendekatan endovaskular juga memiliki kekurangan yaitu risiko kegagalan primer (primary endoleak) yang cukup tinggi terutama pada kasus dimana dilakukan pemasangan stent graft pada segmen aorta yang lebih panjang. Tingginya risiko ini kemungkinan disebabkan oleh struktur jaringan pembuluh aorta yang rapuh pada pasien sindrom Marfan. Penelitian oleh Waterman dkk (2012) menunjukkan bahwa risiko terjadinya kebocoran primer meningkat pada pasien yang mengalami diseksi kronik. ${ }^{7,8,9}$

Adanya kebocoran aneurisma (kegagalan primer) dan degenerasi aneurisma (kegagalan sekunder) mengharuskan pasien untuk dilakukan tindakan endovaskular berulang atau bahkan bedah terbuka. Hal ini akan meningkatkan morbiditas, mortalitas, dan juga pembiayaan bagi pasien. Selain itu diketahui bahwa setelah 8 tahun, kematian akibat aneurisma lebih tinggi pada pasien sindrom Marfan yang menjalani teknik endovaskular dibandingkan pasien yang dilakukan bedah terbuka. Hal ini disebabkan oleh tingginya tingkat ruptur aneurisma berulang pada followup jangka panjang. Sehingga pasien sindrom 
Marfan dengan aneurisma aorta berusia muda dan memiliki angka harapan hidup yang lebih panjang dengan risiko peri-operasi yang rendah akan lebih baik untuk dilakukan teknik bedah terbuka dibandingkan teknik endovaskular. ${ }^{11}$ Sedikitnya jumlah subyek pada penelitianpenelitian yang ada serta waktu follow-up yang singkat menyebabkan efektivitas tata laksana endovaskular masih diragukan jika dibandingkan dengan prosedur bedah terbuka yang merupakan tata laksana standar dan sudah diketahui luaran jangka panjang. Prosedur endovaskular tetap dapat dijadikan alternatif kedua jika pada pasien tidak memungkinkan untuk dilakukan prosedur bedah terbuka. Meskipun demikian tetap diperlukan persiapan konversi bedah terbuka jika selama dilakukan prosedur endovaskular mengalami kegagalan. Selain itu pemantauan secara ketat sangat diperlukan karena tingginya risiko kegagalan primer dan kegagalan sekunder yang dapat meningkatkan mortalitas dan morbiditas pasien sindrom Marfan.

\section{Kesimpulan dan Saran}

Intervensi endovaskular merupakan alternatif yang baik dalam penatalaksanaan aneurisma aorta torako-abdominalis pada pasien dengan sindrom Marfan. Pemilihan prosedur tata laksana baik bedah terbuka maupun endovaskular harus mempertimbangkan kondisi pasien seperti usia dan faktor komorbiditas yang dimilikinya agar tata laksana yang dipilih bersifat aman bagi pasien.

Terbatasnya jumlah pasien pada studi-studi yang ada, latarbelakang perjalanan penyakit yang berbeda-beda pada setiap pasien, dan fasilitas kesehatan yang berbeda maka disarankan untuk dilakukan studi di Indonesia mengenai penatalaksanaan endovaskular pada pasien sindrom Marfan agar diketahui luaran dan tingkat mortalitas sesuai dengan kondisi di Indonesia.

\section{Daftar Referensi}

1. Mahavira A, Siswanto BB. Diagnosis dan management of Marfan syndrome. J. Kardiol Indones. 2013;34:105-12

2. Boersma D, Kloppenburg GTL, Vos JA, van den Heuvel D, de Vries JP. Fenestrated endograft repair of suprarenal aortic patch aneurysm in a patient with Marfan syndrome. Vasc Endovascular Surg. 2012;46(1):66-69 
3. Yuan SH, Jing H. Marfan's syndrome: an overview. Sao Paulo Med J. 2010;128(6):360-6.

4. Cooper DG, Walsh SR, Sadat U, Hayes PD, Boyle JR. Treating the thoracic aorta in Marfan syndrome: Surgery or TEVAR?. J Endovasc Ther. 2009; 16:60-70

5. Canadas V, Vilacosta I, Bruna I, Fuster V. Marfan syndrome: pathophysiology and diagnosis. Nat Rev Cardiol. 2010;7(5):256-65

6. Ikeno $\mathrm{Y}$, Yokowa $\mathrm{K}$, Nakai $\mathrm{H}$, Yamanaka K, Inoue T, et al. Results of staged repair of aortic disease in patients with Marfan syndrome. J Thorac Cardiovasc Surg. 2018:1-10

7. Waterman AL, Feezor RJ, Lee A, Hess JP, Beaver TM, et al. Endovascular treatment of acute and chronic aortic pathology in patients with Marfan syndrome. J Vasc Surg. 2012;55:123441

8. Ince H, Rehders TC, Petzsch M, Kische S, Nienaber CA. Stent-grafts in patients with Marfan syndrome. J Endovasc Ther. 2005; 12:82-88
9. Marcheix B, Rousseau H, Bongard V, Heijmen RH, Nienaber CA. Stent grafting of dissected aorta in patients with Marfan syndrome. JACC Cardiovasc Interv. 2008;1(6):673-80

10. Coselli JS, Green SY, Price MD, Hash JA, Ouyang Y, et al. Results of open surgical repair in patients with Marfan syndrome and distal aortic dissection. Ann Thorac Surg. 2016;101:2193-201

11. Swerdlow NJ, Wu W W, Schermerhorn ML. Open and endovascular management of aortic aneurysms. Circ Res. 2019;124:647-661

12. Kalkat MS, Rahman I, Kotidis K, Davies B, Bonser RS. Presentation and outcome of Marfan's syndrome patients with dissection and thoraco-abdominal aortic aneurysm. European Journal of Cardio-thoracic Surgery. 2007;32:250254

13. Gott VL, Greene PS, Alejo DE, Cameron DE, Naftel DC, et al. Replacement of the aortic root in patients with Marfan. N Engl J Med. 1999;340:1307-1 


\subsection{Alur pencarian teknik endovaskular}

Kriteria eksklusi:

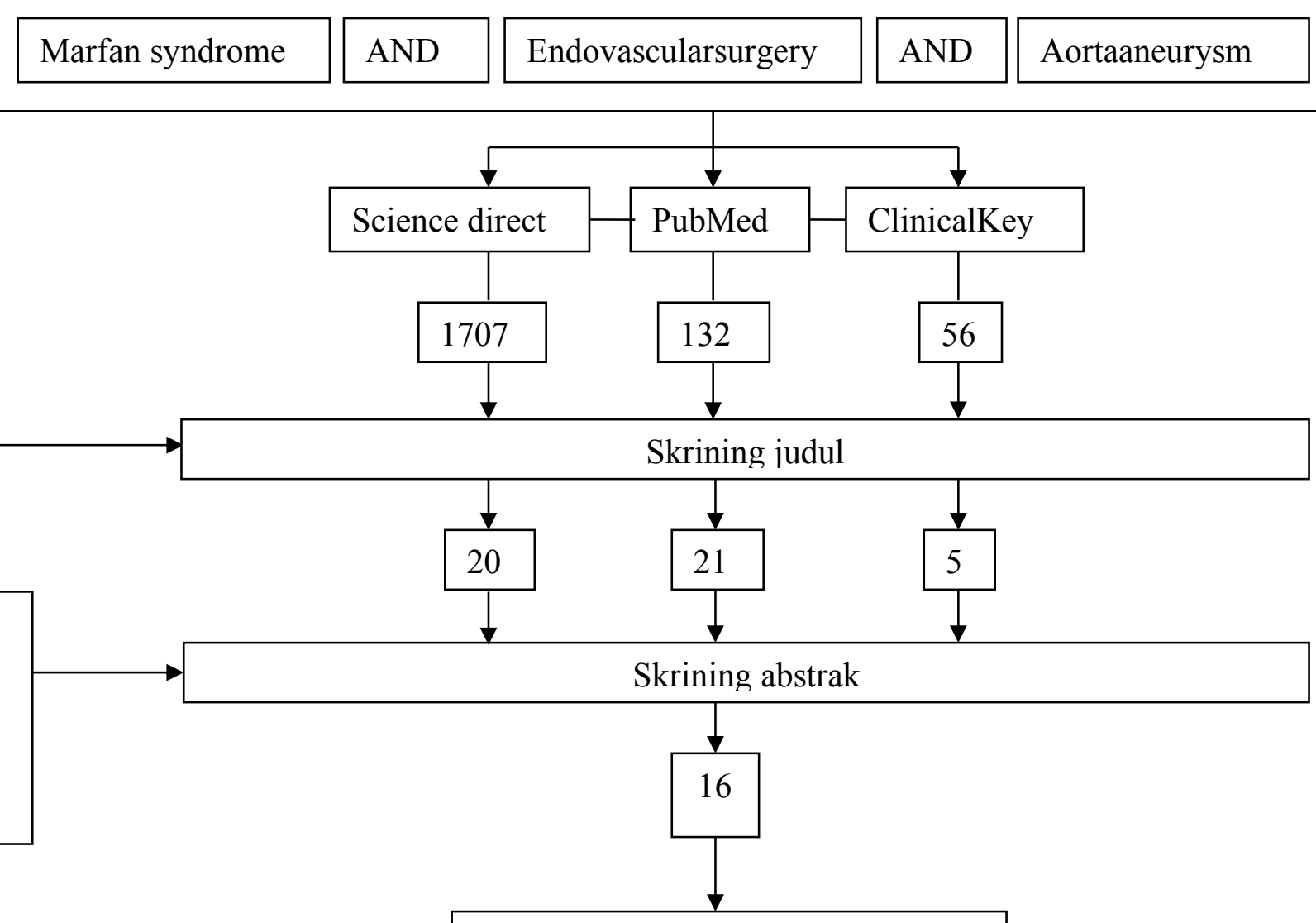

Kriteria inklusi:

- Terdapat full-text

- Membahas luaran hasil tindakan

- Bahasa Inggris

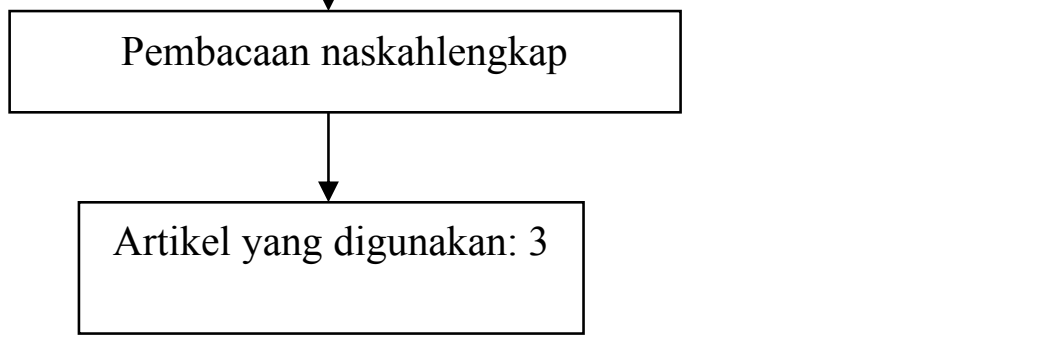


Tabel 4.1 Rangkuman studi endovaskular

\begin{tabular}{|c|c|c|c|c|c|c|c|}
\hline Penulis (Tahun) & Desain Studi & Jumlah Sampel & Usia (Tahun) & Lama follow-up & Luaran & Mortalitas & Level of Evidence \\
\hline $\begin{array}{l}\text { Waterman dkk } \\
\qquad(2012)^{7}\end{array}$ & Retrospektif & 16 pasien & $\begin{array}{l}39,6 \text { tahun } \\
\text { (26-65 tahun) }\end{array}$ & $\begin{array}{c}9,3 \text { bulan } \\
\text { (1-46 bulan) }\end{array}$ & $\begin{array}{c}\text { Sukses : } 6 \text { pasien }(38 \%) \\
\text { Gagal primer: } 7 \text { pasien }(44 \%) \\
\text { Gagal sekunder: } 2 \text { pasien }\end{array}$ & 4 & IV \\
\hline $\begin{array}{l}\text { Marcheix dkk } \\
\quad(2008)^{9}\end{array}$ & Retrospektif & 15 pasien & $\begin{array}{c}38,7 \text { tahun } \\
( \pm 12,8)\end{array}$ & 25 bulan & $\begin{array}{l}\text { Technical success: } 10 \\
\text { Gagal primer: } 5 \\
\text { Gagal sekunder: } 0\end{array}$ & 3 & IV \\
\hline $\begin{array}{c}\text { Ince dkk } \\
(2005)^{8}\end{array}$ & Prospektif & 6 pasien & $\begin{array}{c}33 \text { tahun } \\
( \pm 12,8)\end{array}$ & $12-74$ bulan & $\begin{array}{l}\text { Technical success: } 2 \\
\text { Gagal primer: } 4 \\
\text { Gagal sekunder: } 0\end{array}$ & 1 & IV \\
\hline
\end{tabular}




\subsection{Alur pencarian bedah terbuka}

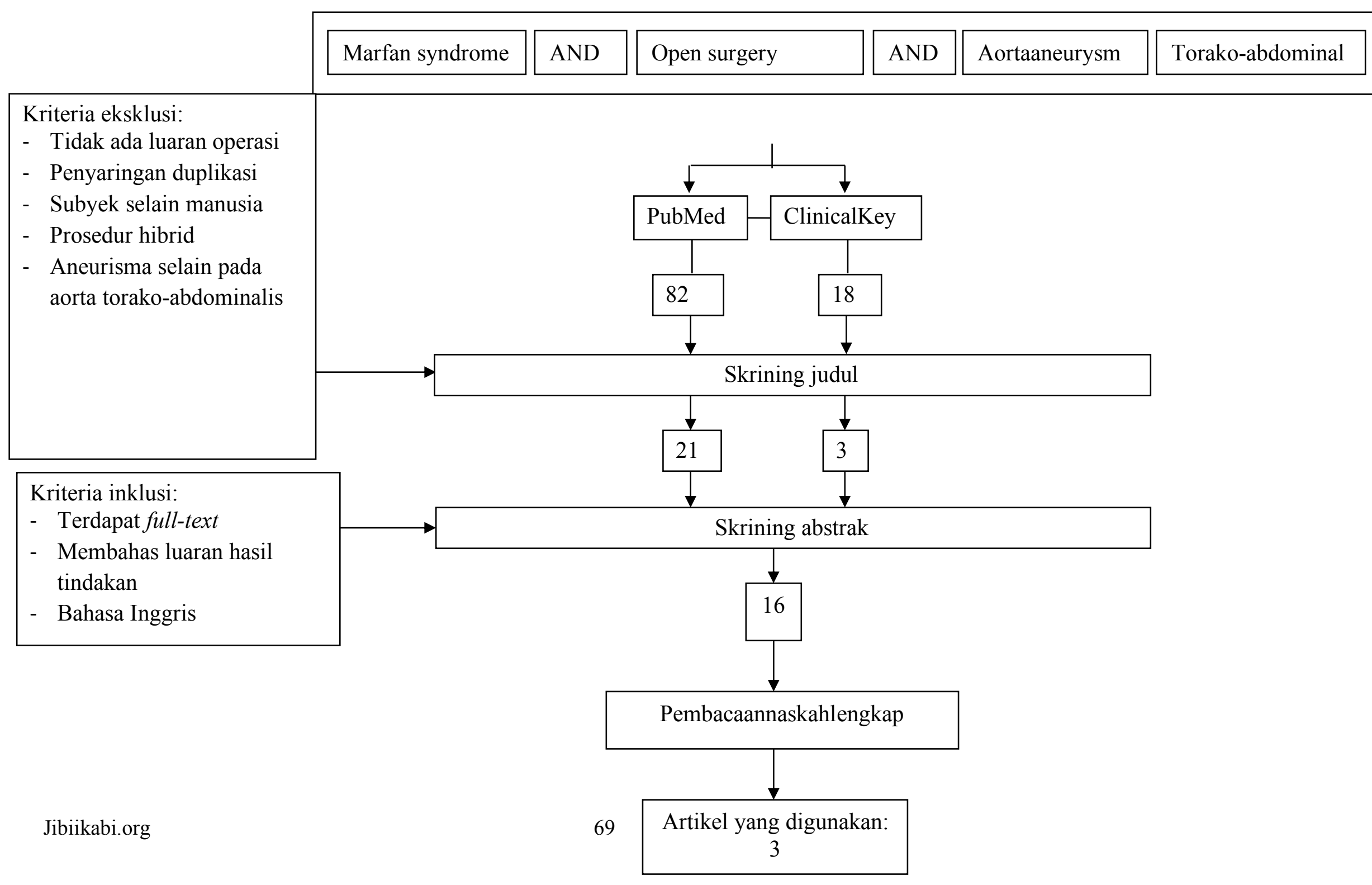


Tabel 4.2 Critical appraisal berdasarkan CASP checklist

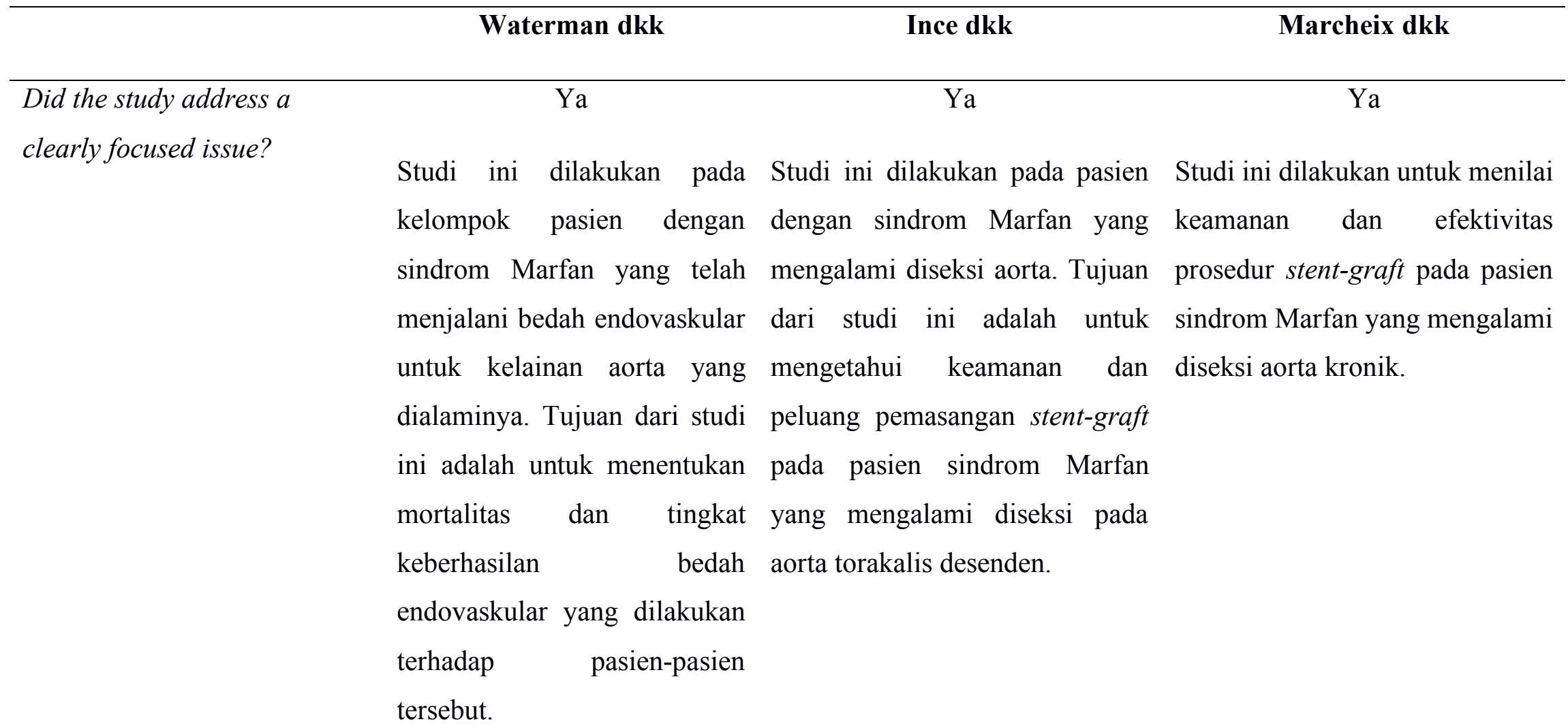


Was the cohort recruited in an Sulit dinilai karena jumlah kasus yang sedikit sehingga semua subyek yang ada dimasukkan ke dalam acceptable way? analisis

Was the exposure accurately Tidak. Artikel yang didapatkan hanya berupa artikel laporan kasus sehingga masing-masing pasien measured to minimize bias? dilaporkan sesuai dengan komorbiditas yang dimiliki masing-masing

\section{Lanjutan tabel 4.2}

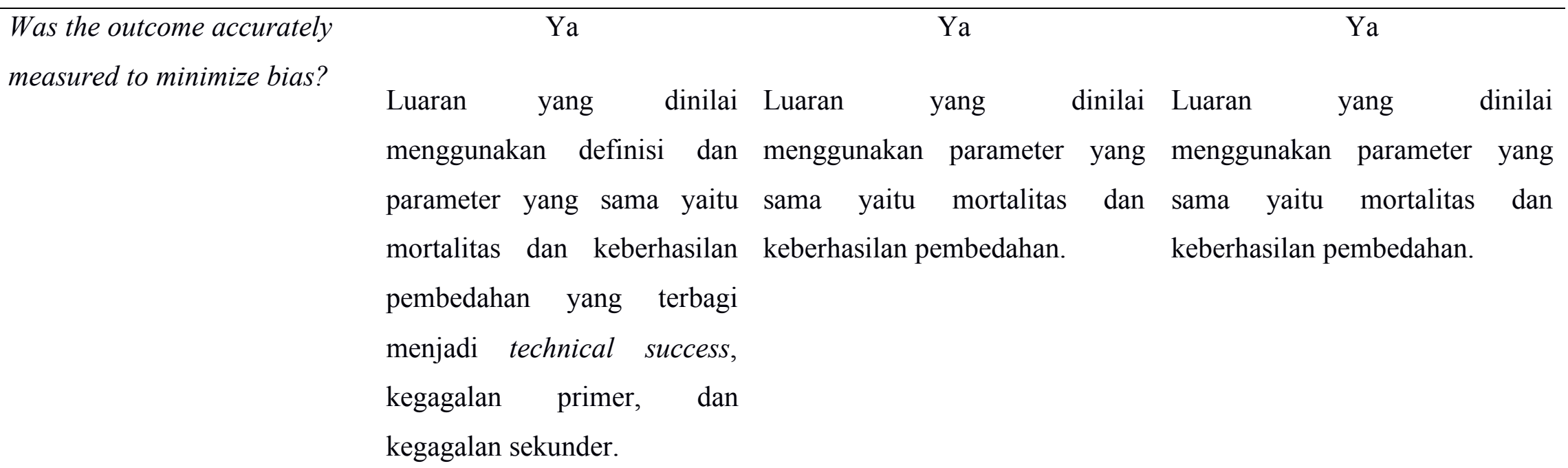


Have the authors identified all important confounding factors?
$\mathrm{Ya}$
Tidak
Ya

mencantumkan
Penulis mencantumkan adanya perbedaan karakteristik pasien yang dinilai dari usia, riwayat bedah aorta sebelumnya, nilai ASA, dan berbagai faktor

komorbid.

\section{Peneliti hanya menyebutkan Penulis} karakteristik pasien yang terdiri diseksi, riwayat bedah aorta dari usia, komorbiditas, penyakit sebelumnya. Faktor komorbid aorta, dan riwayat operasi aorta tidak disebutkan oleh pasien. sebelumnya.

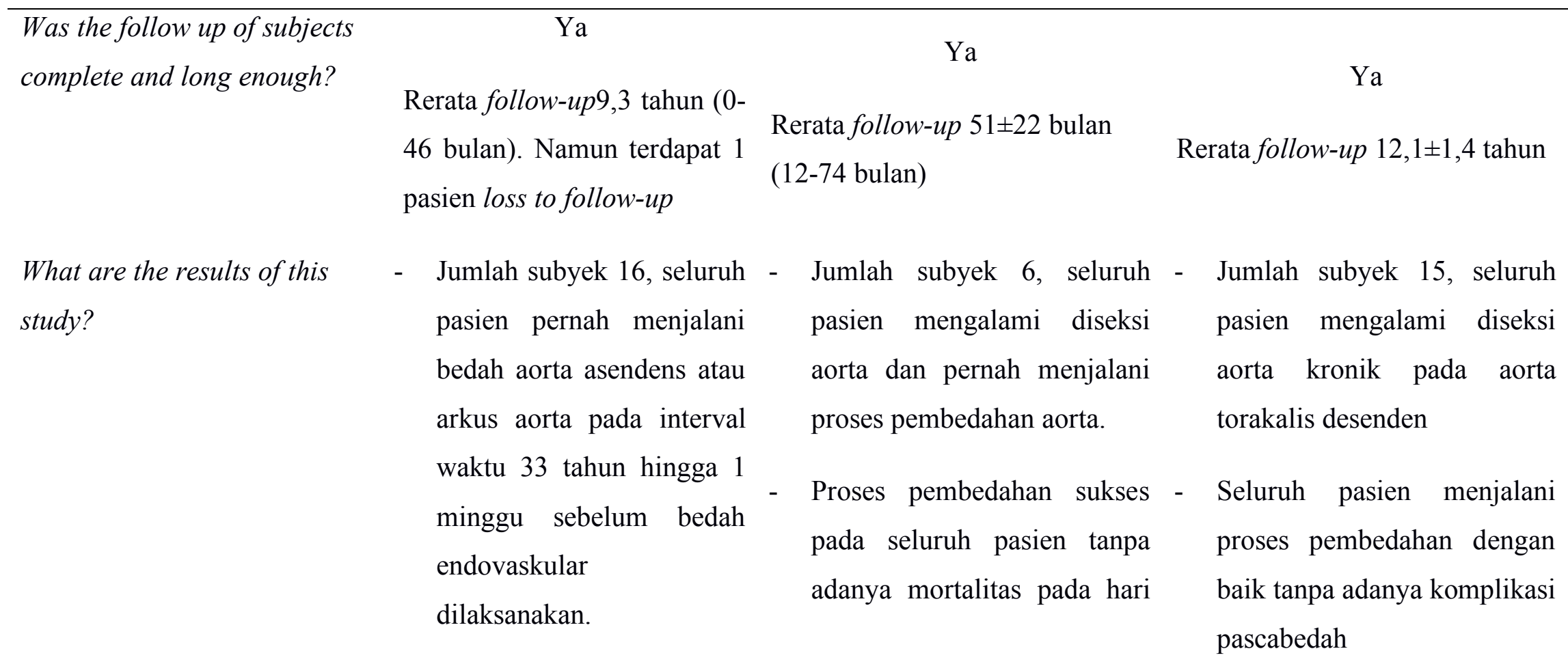




\section{ARTIKEL PENELITIAN}

Patrianef, dkk

- Empat (25\%) pasien meninggal selama masa follow-up

- Enam pasien (38\%) menjalani prosedur pembedahan dengan baik, namun 1 pasien meninggal dalam kurun waktu 1 bulan pascabedah.

- Tujuh (44\%) pasien mengalami kegagalan primer ( 5 pasien menjalani open conversion surgery, 1 pasien menjalani subclavian coil embolization, dan 1 pasien lost to follow-up). Pada akhirnya 3 pasien meninggal dunia pada kelompok ini. ke-30 dan satu tahun pertama pascabedah.

- Dua pasien menjalani bedah rekonstruksi aorta yang mengalami diseksi

- Dua pasien menjalani operasi elektif konversi pada bulan ke-22 dan ke-43 pasca implantasi stent-graft

- Satu pasien meninggal setelah 12 bulan pasca bedah endovaskular. 
- Dua pasien mengalami

kegagalan sekunder,

selanjutnya 1 pasien

menjalani TEVARkarena

diseksi aorta akut dengan

malperfusi sedangkan

pasien yang lain menjalani

open conversion surgery

setelah EVAR kedua

dengan 4 pembuluh

"chimney" stent graft.

Kedua pasien kondisinya

stabil tanpa adanya

perburukan penyakit.
Patrianef, dkk

terdapat 12 pasien yang tetap hidup. Diantara pasien-pasien terdapat 5 pasien yang berhasil mengalami konversi pascabedah terbuka

- Terdapat 6 pasien yang mengalami trombosis sempurna, dan terdapat 1 pasien dengan trombosis parsial.

How precise are the results?

Pada studi tidak dicantumkan Pada studi tidak dicantumkan hasil analisis statistik dan tidak hasil analisis statistik dan tidak
Pada studi tidak dicantumkan

hasil analisis statistik dan tidak 
disebutkan confidence interval disebutkan confidence interva serta rentang nilai.

$l$ serta rentang nilai.

Do you believe the results?

Can the results be applied to

the local population?

\section{Sulit ditentukan}

Penelitian ini merupakan suatu

penelitian retrospektif dengan

jumlah subyek sedikit dengan

karakteristik subyek yang

berbeda-beda.

Ya
Sulit ditentukan

Penelitian ini merupakan suatu penelitian retrospektif dengan jumlah subyek sedikit dan komorbiditas diketahui. yang tidak
Ya disebutkan confidence interva lserta rentang nilai.

Sulit ditentukan

Penelitian ini merupakan suatu penelitian retrospektif dengan jumlah subyek sedikit dengan arakteristik subyek yang berbeda-beda.

Do the results of this study fit with other available

evidence?
Ya

Ya

Hasil studi secara umum menunjukkan adanya

kesesuaian dengan hasil pada studi lain.
Ya

Hasil studi secara umum Hasil studi secara umum menunjukkan adanya kesesuaian menunjukkan adanya kesesuaian dengan hasil pada studi lain. dengan hasil pada studi lain. 
What are the implications of this study for practice?
Dari ketiga artikel diketahui bahwa tata laksana endovaskular dapat dijadikan tata laksana alternatif jika pasien tidak dapat dilakukan prosedur bedah terbuka

\section{Tabel 4.3 Rangkuman studi bedah terbuka}

\begin{tabular}{|c|c|c|c|c|c|c|}
\hline $\begin{array}{l}\text { Penulis } \\
\text { (Tahun) }\end{array}$ & Desain Studi & $\begin{array}{l}\text { Jumlah } \\
\text { Sampel }\end{array}$ & $\begin{array}{c}\text { Usia } \\
\text { (Tahun) }\end{array}$ & Prosedur & Luaran & $\begin{array}{l}\text { Level of } \\
\text { Evidence }\end{array}$ \\
\hline \multirow{6}{*}{$\begin{array}{l}\text { Ikeno dkk } \\
(2018)^{6}\end{array}$} & \multirow[t]{6}{*}{ Retrospektif } & \multirow[t]{6}{*}{82 pasien } & \multirow{6}{*}{$\begin{array}{l}41,7 \pm 14,9 \\
\text { tahun }\end{array}$} & $\begin{array}{lll}\text { Penggantian } & \text { pangkal }\end{array}$ & Mortalitas $0,8 \%$ & \multirow[t]{6}{*}{$I V$} \\
\hline & & & & Penggantian total arkus aorta & Cedera medula spinalis $1,7 \%$ & \\
\hline & & & & $(9,3 \%)$ & Survival dalam kurun 10 tahun & \\
\hline & & & & aorta dan total arkus aorta $(13,11)$ & Rekuren repair setelah $2,5 \pm 3,8$ & \\
\hline & & & & Penggantian aorta desenden & tahun $(24 / 118)$ & \\
\hline & & & & $(4,34 \%)$, repair aorta torako- & & \\
\hline Coselli dkk & Retrospektif & 127 & $43,4 \pm 12,5$ & Bedah aneurisma aorta torako- & Early outcome: & $I V$ \\
\hline$(2016)^{10}$ & & & tahun & abdominal pada pasien sindrom & $\begin{array}{l}\text { Kematian selama operasi } 4 \% \text {, } \\
\text { kematian } 30 \text { hari pascabedah }\end{array}$ & \\
\hline
\end{tabular}


Marfan dan diseksi distal aorta

DeBakey tipe I dan III

\section{Kalkat dkk Retrospektif} $(2007)^{12}$
22 pasien 38,5 tahun Crawford surgery
$2 \%$, non-permanen stroke $1 \%$, defisit korda spinalis $4 \%$, disfungsi ginjal akut $9 \%$, gagal ginjal permanen yang membutuhkan HD 5\%, ariitmia atrium $13 \%$, trakeostomi $13 \%$, paralisis pita suara kiri $34 \%$, perdarahan yang membutuhkan operasi ulang $8 \%$, lama perawatan di ICU 5 hari (3-7 hari), rerata lama perawatan di RS 12 hari (9-18 hari)

Late outcome:

Meninggal $16 \%, \quad$ survival $87 \% \pm 3 \%$ dalam kurun waktu 2 tahun dan $75 \% \pm 5 \%$ dalam kurun waktu 8 tahun

2 pasien menjalani bedah re- $I V$ eksplorasi akibat perdarahan, 2 pasien trakeostomi, 1 pasien mengalami infark serebri. Lama 
perawatan ICU 8 hari, lama perawatan di RS 19 hari. Lama follow-up 56 bulan dengan survival $90 \%$

Tabel 4.4 Critical appraisal berdasarkan CASP checklist

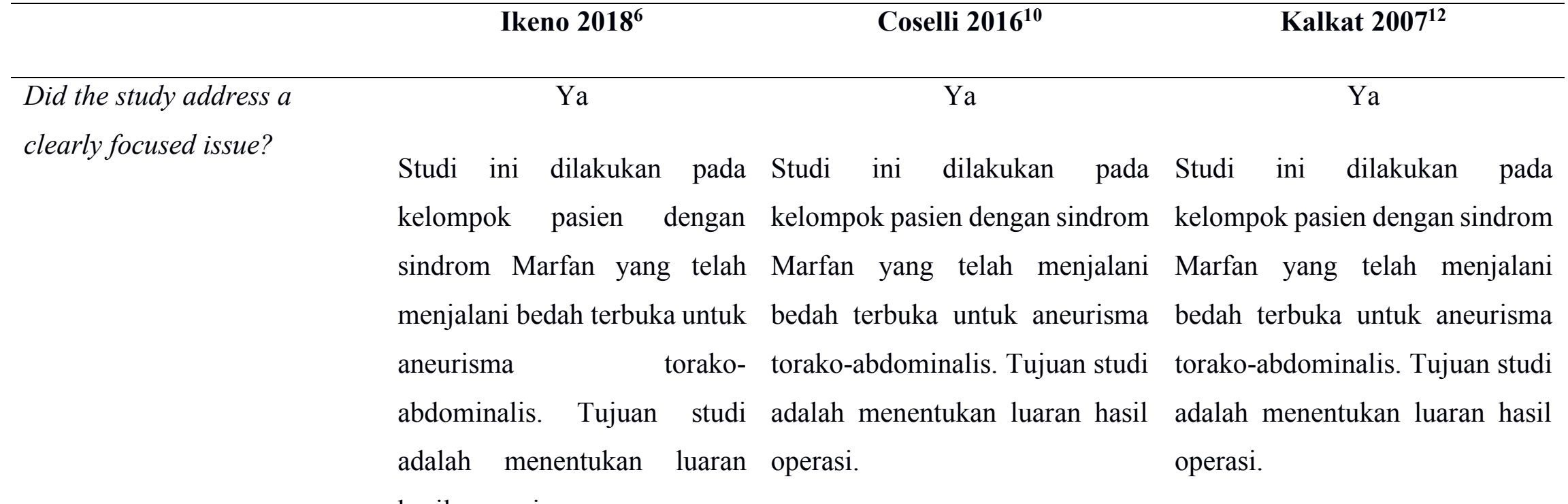

hasil operasi.

Was the cohort recruited in an acceptable way? 
Was the exposure accurately

measured to minimize bias?

Was the outcome accurately measured to minimize bias?

important confounding

factors?

Was the follow up of subjects

complete and long enough?

What are the results of this

study?

Jibiikabi.org
Ya
Ya

Luaran adalah komplikasi

pascabedah
$\mathrm{Ya}$

Ya

$\mathrm{Ya}$

Ya

Rereata follow-up 10 tahun Rerata follow-up 8 tahun

Early outcome:

2 pasien menjalani bedah re-

Stroke $1,7 \%$

Cedera medula spinalis $1,7 \%$

Survival dalam kurun 10 tahun

$95,8 \pm 2,4 \%$

Rekuren repair setelah $2,5 \pm 3,8$

Kematian selama operasi $4 \%$, kematian 30 hari pascabedah $2 \%$, non-permanen stroke $1 \%$, defisit korda spinalis 4\%, disfungsi ginjal akut 9\%, gagal ginjal permanen yang membutuhkan HD 5\%, ariitmia atrium $13 \%$,
Luaran adalah komplikasi pascabedah ksplorasi akibat perdarahan, 2 pasien trakeostomi, 1 pasien mengalami infark serebri. Lama perawatan ICU 8 hari, lama perawatan di RS 19 hari. Lama follow-up 56 bulan dengan survival $90 \%$ 
tahun $(24 / 118)$

trakeostomi $13 \%$, paralisis pita suara kiri 34\%, perdarahan yang membutuhkan operasi ulang $8 \%$, lama perawatan di ICU 5 hari (37 hari), rerata lama perawatan di RS 12 hari (9-18 hari)

\section{Late outcome:}

- Meninggal 16\%, survival $87 \% \pm 3 \%$ dalam kurun waktu 2 tahun dan $75 \% \pm 5 \%$ dalam kurun waktu 8 tahun

How precise are the results? Sulit dinilai Sulit dinilai

Sulit dinilai

Pada studi tidak dicantumkan Pada studi tidak dicantumkan hasil analisis statistik dan tidak hasil analisis statistik dan tidak disebutkan confidence disebutkan confidence intervalserta rentang nilai. intervalserta rentang nilai. 
Can the results be applied to

the local population?

Do the results of this study fit

Ya

Ya

Ya

with other available

evidence?

Hasil studi secara umum Hasil studi secara umum Hasil studi secara umum menunjukkan adanya menunjukkan adanya kesesuaian menunjukkan adanya kesesuaian kesesuaian dengan hasil pada dengan hasil pada studi lain. dengan hasil pada studi lain. studi lain.

What are the implications of this study for practice?
Dari ketiga artikel diketahui bahwa teknik bedah terbuka memiliki efektivitas yang baik dibuktikan dengan tingginya angka ketahanan hidup 


\title{
Hubungan Kadar Malondialdehide (MDA) Testis dengan Kualitas Spermatozoa pada Tikus Putih Strain Wistar (Rattus novergicus) Diabetes Tipe I
}

\author{
Jauhari Deslo ${ }^{1}$, Jufriady Ismy ${ }^{2}$, Dasrul Dasrul ${ }^{3}$ \\ ${ }^{1}$ Program Pendidikan Dokter Spesialis Ilmu Bedah, Fakultas Kedokteran Universitas Syiah Kuala/ \\ Rumah Sakit Umum dr. Zainoel Abidin Banda Aceh. \\ ${ }^{2}$ Divisi Urologi, Departemen Bedah Fakultas Kedokteran Universitas Syiah Kuala/ Rumah Sakit \\ Umum dr. Zainoel Abidin Banda Aceh. \\ ${ }^{3}$ Staf Dosen Kedokteran Hewan, Fakultas Kedokteran Hewan Universitas Syiah Kuala/ Rumah Sakit \\ Umum dr. Zainoel Abidin Banda Aceh.
}

\begin{abstract}
Abstrak
Latar Belakang. Hyperglikemia pada diabetes melitus tipe 1 diduga berperan dalam peningkatan radikal bebas (oksidan) dan penurunan antioksidan darah. Peningkatan senyawa radikal bebas memicu peroksidasi lipid pada darah dan testis yang ditandai dengan peningkatan kadar malondialdehid (MDA) testis dan penurunan kualitas spermatozoa.

Tujuan Penelitian. Penelitian ini bertujuan untuk mengetahui hubungan kadar MDA testis dengan kualitas spermatozoa tikus putih diabetes mellitus tipe 1 .

Metode Penelitian. Desain penelitian ini adalah static comparison group dan menggunakan uji analitik observasional. Subjek penelitian dibagi menjadi 2 kelompok yaitu 16 ekor tikus putih normal dan 16 ekor tikus putih dengan diabetes mellitus tipe 1 yang diinduksi aloksan. Kadar MDA spermatozoa diukur dengan menggunakan uji TBA dan spektrofotometer. Penilaian kualitas spermatozoa (jumlah, persentase motilitas dan morfologi normal spermatozoa) dilakukan dengan menggunakan standar WHO. Data kadar MDA testis dan kualitas spermatozoa (jumlah, motilitas dan morfologi spermatozoa) dianalisis dengan uji-t independent, sedangkan hubungan antara kadar MDA dengan kualitas spermatozoa dianalisis dengan korelasi pearson menggunakan spss 21.0 .

Hasil Penelitian. Hasil analisis menunjukkan bahwa kadar MDA testis tikus normal berbeda secara nyata $(\mathrm{p}<0,05)$ dibandingkan dengan tikus putih DM. Jumlah, motilitas dan morfologi normal spermatozoa tikus putih normal berbeda secara nyata $(\mathrm{p}<0,05)$ dibandingkan dengan pada tikus putih DM. Terdapat hubungan yang kuat antara kadar MDA testis dengan jumlah, motilitas dan morfologi normal spermatozoa dengan arah negatif $(\mathrm{R}=-0,877 ;-0,804$ dan - 0,795).
\end{abstract}


Indonesian J Surg:

Volume 47 No.2 Oktober 2019

Kesimpulan. Kadar MDA testis berhubungan secara kuat dengan kualitas (jumlah, motilitas dan morfologi normal) spermatozoa dengan arah negatif.

Kata kunci: Diabates mellitus, malondialdehida testis, kualitas spermatozoa 
The Relationship of Testicular Malondialdehyde (MDA) Levels with Spermatozoa Quality in Wistar Strain White Mice (Rattus novergicus) with Type I Diabetes

\author{
Jauhari Deslo ${ }^{1}$, Jufriady Ismy ${ }^{2}$, Dasrul Dasrul ${ }^{3}$
}

\begin{abstract}
Background. Hyperglycemia in type 1 diabetes mellitus is thought to play a role in increasing free radicals (oxidants) and decreasing blood antioxidants. The increase in free radical compounds triggers lipid peroxidation in the blood and testicle which is characterized by an increase in the amount of testicle malondialdehyde (MDA) and a decrease in the quality of spermatozoa.
\end{abstract}

Objective. This study aims to determine the relationship of the amount of MDA and the quality of spermatozoa of type 1 diabetes mellitus white mice.

Materials and Methods. The design of this study was static comparison group and used observational analytic tests. The research subjects were divided into 2 groups, namely 16 normal white mice and 16 type 1 diabetes mellitus white mice induced by alloxan. The amount of MDA of spermatozoa was measured using the TBA test and spectrophotometer. The observation of the quality of spermatozoa was based on the number, percentage of motility and morphology of normal spermatozoa carried out using eosin-negrosin staining. The data in the form of spermatozoa MDA amount and the percentage of viability were analyzed by paired t-test and Pearson correlation using SPSS 21.0.

Result. The results of the analysis showed that the amount of MDA in normal mice's testicle were significantly different $(\mathrm{p}<0.05)$ compared to DM white mice. The number, motility and normal morphology of spermatozoa of normal white mice differed significantly $(p<0.05)$ compared to DM white mice. There was a strong relationship between testicle amount of MDA with the number, motility and normal morphology of spermatozoa with the negatifdirection $(\mathrm{R}=-0.877$; 0.804 and -0.795$)$.

Conclusions. The amount of testicle MDA were strongly associated with the number, motility and normal morphology of spermatozoa with negative direction.

Keywords: Diabetes mellitus, testicle of malondialdehyde, quality of spermatozoa 


\section{Pendahuluan}

Diabetes mellitus (DM) merupakan gangguan metabolisme kronik yang kompleks tidak menular, dengan karakteristik tingginya kadar glukosa dalam darah (hiperglikemia) yang terjadi karena kelainan sekresi insulin, kerja insulin atau keduanya. ${ }^{1}$ Penyakit DM menjadi sangat penting karena jumlah penderitanya makin meningkat tiap tahun, dan juga dapat menyebabkan berbagai masalah medis, psikologis dan seksual. ${ }^{2}$ Lebih lanjut Amaral dkk., tahun 2008, menyatakan bahwa prevalensi terjadinya disfungsi seksual pada pria diabetes hampir mencapai 50\%, sedangkan pada wanita diabetes memiliki prevalensi yang lebih rendah dibandingkan dengan pria diabetes. ${ }^{3}$ Sekitar 90\% pria diabetes mengalami disfungsi seksual yang meliputi disfungsi testis, menurunnya libido (impotensi), dan penurunan tingkat fertilitas. Disfungsi ereksi dilaporkan sekitar $50 \%$ terjadi pada pria diabetes dan frekuensi disfungsi ereksi pada penderita diabetes meningkat $25 \%$ di atas usia 35 tahun dan 70 $\%$ sesudah usia 60 tahun, serta $30 \%$ penderita diabetes mengalami penurunan libido. ${ }^{4}$
Selain itu, Kanter et al., tahun 2012 juga menyatakan bahwa dampak yang ditimbulkan akibat penyakit diabetes melitus, terutama pada organ testis diantaranya ialah mengecilnya ukuran serta berat testis, peningkatan abnormalitas pada spermatogenesis yang ditandai dengan menurunnya jumlah sperma yang dihasilkan. ${ }^{5}$ Peningkatan jumlah sel yang mengalami apoptosis pada sel germinal (terutama spermatogonium dan spermatosit) dalam tubulus seminiferus telah dilaporkan juga terjadi pada hewan uji tikus diabetes. ${ }^{6}$

Beberapa peneliti membuktikan faktor utama pemicu terjadinya disfungsi ereksi dan penurunan kualitas spermatozoa pada penderita diabetes mellitus adalah akibat peningkatan produksi senyawa oksigen reaktif (reactive oxygen spesies/ROS) dalam tubuh seperti superoksida $(\mathrm{O} 2 \bullet-)$, radikal hidroksil $(\mathrm{OH} \bullet)$, serta hidrogen peroksida $\left(\mathrm{H}_{2} \mathrm{O}_{2}\right)^{1,7}$

Correspondents:

Jauhari Deslo

PPDS Ilmu Bedah

email : kearyumm@gmail.com 
Peningkatan ROS yang melebihi kapasitas baik untuk memahami patologi dari enzim antioksidan dalam tubuh untuk pengurangan motilitas sperma pada kondisi menetralisirnya dikenal dengan istilah stress infeksi urogenital atau status inflamasi. ${ }^{10}$ Selain oksidatif yang selanjutnya menyebabkan itu adanya peningkatan MDA dalam membran terjadinya reaksi peroksidasi pada lipid, protein, dan DNA membrane sel-sel tubuh termasuk plasma spermatozoa telah dilaporkan menambah rigiditas struktur, mengubah didalamnya sel-sel interstitial testis dan spermatozoa $^{7,8}$

kemampuan spermatozoa untuk berfusi dengan oosit yang ditandai dengan penurunan motilitas spermatozoa dan buruknya kualitas semen. ${ }^{11}$ Stress oksidatif akibat diabetes militus juga menjadi pencetus produksi malondialdehide (MDA). Malondialdehide merupakan hasil dari oksidasi polyunsaturated fatty acid (PUFA). Akibat proses pembentukan malondialdehide, biomarker ini menjadi penanda biologis yang paling sering digunakan sebagai indikator peroksidasi lemak. Senyawa ini merupakan produk peroksidasi lemak yang relatif konstan terhadap proporsi peroksidasi lemak, oleh karena itu MDA merupakan indikator yang tepat untuk mengetahui kecepatan (rate) proses peroksidasi lemak in vivo. ${ }^{9,10}$ MDA juga menjadi indikator tingginya kadar radikal bebas dalam tubuh dengan ditunjukkan oleh rendahnya akitifitas dari enzim antioksidan. Semakin tinggi kadar radikal bebas maka makin tinggi kadar MDA dalam tubuh. Berkaitan dengan infertilitas dan kualitas spermatozoa, MDA telah dilaporkan menjadi biomarker yang

Tavilani dkk menyatakan bahwa konsentrasi MDA signifikan lebih tinggi pada kondisi asthenozoospermic dibandingkan pada laki-laki normozoospermik. Nilai MDA pada plasma sperma asthenozoospermic dan normozoospermic masing-masing adalah $1,35 \pm$ 0,42 dan1,2 $\pm 0,3 \mathrm{nmol} / \mathrm{ml}$ plasma seminal.

Pada studi lain didapatkan hubungan MDA dengan status infertilitas, penurunan jumlah sperma, motilitas dan morfologi. ${ }^{12,13}$ Namun sampai sejauh ini belum ditemukan laporan yang membahas bagaimana hubungan kadar MDA jaringan testis dengan kualitas (jumlah, motilitas dan morfologi normal) spermatozoa pada penderita diabetes mellitus. Berdasarkan uraian diatas maka, peneliti tertarik untuk melakukan suatu penelitian yang bertujuan untuk mengkaji hubungan antara kadar malondialdehide (MDA) jaringan testis dengan 
kualitas spermatozoa tikus strain wistar 3-4 bulan, diperoleh dari Fakultas Kedokteran (rattusnovergicus) diabetes militus.

Hewan Universitas Syiah Kuala sebanyak 32 ekor. Dilakukan homogenisasi sampel Hasil penelitian ini diharapkan dapat penelitian dimana sebelum perlakuan tikus meningkatkan pemahaman mengenai ditimbang, diukur suhu rektal yang telah mekanisme infertilitas melalui pendekatan biomolekuler, dan mengetahui peran dari MDA jaringan testis terhadap kualitas spermatozoa sehingga dapat digunakan sebagai biomarker infertilitas pria.

\section{Metode}

\section{Rancangan Penelitian}

Penelitian ini merupakan penelitian experimental laboratory dengan rancangan static comparison group. Terdapat dua kelompok yaitu perlakuan kondisi tikus diabetes militus dan tanpa diabetes militus.

\section{Lokasi dan Waktu Penelitian}

Lokasi penelitian dilakukan di Laboratorium Farmakologi Fakultas Kedokteran Hewan Universitas Syiah Kuala Banda Aceh, selama 3 bulan mulai dari September hingga Nopember 2018.

\section{Persiapan hewan percobaan}

Tikus putih (rattus novergicus) strain Wistar, berjenis kelamin jantan, dewasa, berusia dilakukan adaptasi selama dua minggu dengan dipelihara di dalam kandang.Suhu dalam kandang diatur pada suhu kamar, setiap harinya tikus diberi makan berupa pelet sebanyak 20 gram dan air minum diberikan secara ad libitum.

\section{Pembuatan hewan perlakuan Diabetes Melitus}

Pembuatan tikus diabetes dilakukan menurut Kim et al. (2006), tikus putih strain Wistar jantan dipuasakan selama 24 jam kemudian diinjeksi dengan aloksan monohidrat yang dilarutkan dalam larutan $\mathrm{NaCl}$ fisiologis steril dengan dosis $120 \mathrm{mg} / \mathrm{kg}$ bobot badan secara intraperitoneal. Setelah 7 hari penyuntikan dilakukan pemeriksaan glukosa darah dengan menggunakan Glukometer (EZ Smart).Tikus putih mengalami diabetes militus dengan bukti kadar glukosa puasa $>126 \mathrm{mg} / \mathrm{dl}$.

\section{Pemeriksaan Glukosa Darah}

Pengukuran glukosa darah menggunakan Glukometer (EZ Smart), glukotest ini secara otomatis akan berfungsi ketika strip dimasukan 
dan akan tidak berfungsi ketika strip dicabut. Darah diambil dengan menusuk ekor tikus dengan jarum kecil sampai keluar darah, dengan menyentuhkan setetes darah ke strip, reaksi dari wadah strip akan otomatis menyerap darah ke dalam strip melalui aksi kapiler. Ketika wadah terisi penuh oleh darah, alat akan mulai mengukur kadar glukosa darah, hasil pengukuran dibaca selama 9 detik setelah darah masuk strip.

\section{Pengambilan sekresi cauda epididimis}

Setelah pemberian perlakuan selama 60 hari, semua tikus dibunuh dengan cara pemberian anestesi inhalasi menggunakan kloroform. Lalu tikus diletakkan pada nampan dengan posisi ventral dan dilakukan pembedahan untuk mendapatkan organ reproduksi. Kemudian organ testis beserta epididimis sebelah kanan diambil dan diletakkan ke dalam cawan petri yang berisi $\mathrm{NaCl}$ 0,9\%. Dengan menggunakan mikroskop pembesaran 40 kali cauda epididimis dipisahkan dengan cara memotong bagian proksimal corpus epididimis dan bagian distal vas deferens. Selanjutnya cauda epididimis dimasukkan ke dalam gelas arloji yang berisi $1 \mathrm{ml} \mathrm{NaCl} 0,9 \%$ hangat $\left(37^{\circ} \mathrm{C}\right)$, kemudian bagian proksimal cauda dipotong sedikit dengan gunting lalu cauda ditekan dengan perlahan hingga cairan epididimis keluar dan tersuspensi dengan $\mathrm{NaCl}$ 0,9\%. Suspensi spermatozoa yang telah diperoleh dilakukan pengamatan kualitas spermatozoa yang meliputi: konsentrasi, motillitas dan morfologi normal spermatozoa.

\section{Penilaian kadar MDA jaringan Testis}

Penilaian kadar MDA dilakukan secara in vivo menggunakan endogen yang bereaksi terhadap TBA, berikut cara pembuatan lisat dan preparat $\mathrm{MDA}^{44}$

- Siapkan $1 \times$ solusi reagen TBA / TCA / HCl r dengan mengencerkan larutan stok 4 kali lipat dalam air. Sambil diaduk solusi dengan pengaduk magnet, tambahkan BHT ke konsentrasi akhir $0,03 \%$

- Lisat testis disentrifugasi selama 20 menit dengan kecepatan 8000 rpm

- Supernatan yang terbentuk dari hasil sentrifugasi diambil100 $\mu 1$ ditambah $550 \mu 1$ akuades, $100 \mu 1$ TCA $100 \mu 1$ TCA kemudian divortex, ditambahkan $250 \mu \mathrm{l}$ HCL $1 \mathrm{~N}$ kemudian divortex.

- Ditambahkan $100 \mu$ l NaThio 1\% lalu divortex kembali. Setelah itu disentrifugasi dengan kecepatan 500 rpm selama 15 menit. 
- Supernatan yang terbentuk dipisahkan dan dipindahkan pada mikrotube baru. Setelah itu, dipanaskan dalam water bath $100^{\circ} \mathrm{C}$ selama 30 menit.

- Sampel kemudian diukur absorbansinya dengan persentase spektofotometer (\%) untuk menilai kadar MDA dari cairan lisat testis.

\section{Analisa Data}

Data kadar MDA testis dan kualitas spermatozoa (motilitas, morfologi normal dan jumlah sel sperma) yang diperoleh terlebih dahulu dilakukan uji normalitas dan homogenitas. Uji normalitas menggunakan uji Saphiro-Wilk dan homogenitas menggunakan uji Levene. Jika didapatkan distribusi data yang normal dan homogen, maka dilakukan analisa data dengan uji t-independent. Sedangkan untuk melihat hubungan antara kadar MDA dengan kualitas spermatozoa (jumlah, motilitas dan morfologi normal) dilakukan dengan uji korelasi pearson.

\section{Hasil}

\section{Kadar MDA Testis tikus putih}

Malondialdehida (MDA) merupakan senyawa hasil peroksidasi lipid yang umumnya digunakan sebagai indikator terjadinya stres oksidatif. Hasil pemeriksaan kadar MDA testis menggunakan metode Thiobarbituric Acid Reactive Subtances (TBARs), didapatkan kadar MDA testis pada kelompok tikus putih DM yang diinduksi aloksan (KP), lebih tinggi dibandingkan dengan kadar MDA testis pada kelompok tikus putih normal (KN) sebagaimana terlihat pada Tabel 1.

Selanjutnya untuk menentukan apakah data kadar MDA testis berdistribusi normal, data dianalisis dengan uji normalitas menggunakan uji Saphiro-Wilk. Hasil uji normalitas terhadap kadar MDA testis disajikan dalam tabel 2.

Hasil dari uji Shapiro-Wilk pada Tabel 2 didapatkan bahwa data terdistribusi secara normal dimana nilai $p$ untuk kelompok kontrol (KN) dan kelompok perlakuan KP, adalah $>0.05$. Untuk melihat homogenitas data, maka data kemudian dilanjutkan dengan uji Levence. Hasil uji Levence untuk terhadap kadar MDA testis pada penelitian disajikan dalam tabel 3 .

Nilai signifikan untuk uji keseragaman varians menggunakan uji Levence menunjukkan 0,56 ( $p$ $>0.05)$. Hal ini menandakan bahwa data yang diperoleh homogen, maka kemudian dilanjutkan dengan analisa data menggunakan 
uji t-independent yang dilakukan untuk untuk kelompok tikus normal (KN) dan membandingkan kadar MDA testis dari kelompok tikus putih DM (KP), adalah $>0.05$, kelompok KN dan KP. Hasil uji t-independent dan untuk melihat homogenitas data, maka data disajikan pada Tabel 4. kemudian dilanjutkan dengan uji Levence. Hasil uji Levence untuk terhadap data kualitas Berdasarkan Tabel 4 di, menunjukkan bahwa kadar MDA testis pada kedua kelompok tikus normal dan tikus DM berbeda secara bermakna $(\mathrm{p}=0,000)$. Hasil ini membuktikan bahwa diabetes mellitus mampu meningkatkan kadar MDA testis tikus putih.

\section{Kualitas Spermatozoa}

Pemeriksaan kualitas spermatozoa tikus putih pada penelitian ini berdasarkan pada jumlah spermatozoa, persentase motilitas spermatozoa dan morfologi abnormalitas spermatozoa. Hasil pengamatan rerata kualitas spermatozoa tikus putih normal dan tikus DM dapat dilihat pada Tabel 5.

Untuk menentukan apakah data kualitas (jumlah, motilitas dan morfologi normal) spermatozoa berdistribusi normal, maka data dianalisis dengan uji normalitas menggunakan uji Saphiro-Wilk. Hasil uji normalitas terhadap kualitas spermatozoa disajikan dalam tabel 6.

Hasil dari uji Shapiro-Wilk didapatkan bahwa data terdistribusi secara normal dimana nilai $p$ spermatozoa pada penelitian disajikan dalam tabel 7.

Nilai signifikan untuk uji keseragaman varians menggunakan uji Levence menunjukkan $p>$ 0.05.Hal ini menandakan bahwa data yang diperoleh homogen, maka kemudian dilanjutkan uji t-independent. Hasil analisa data evaluasi kualitas spermatozoa dapat dilihat pada tabel 8 .

Berdasarkan hasil uji $\mathrm{T}$ pada Tabel 8, menunjukkan bahwa kualitas berdasarkan jumlah, persentase motilitas dan persentase morfologi normal spermatozoa pada kelompok tikus putih normal dan tikus putih DM berbeda secara bermakna dengan nilai p masing-masing adalah 0,000; 0,000 dan 0,000. Hasil ini dapat disimpulkan bahwa perlakuan diabetes mellitus tipe 1 pada tikus putih dapat menurunkan kualitas spermatozoa (jumlah, persentase motilitas dan morfologi normal spermatozoa) secara nyata. 


\section{Hubungan kadar MDA testis dengan Pembahasan}

\section{kualitas spermatozoa tikus putih}

Hasil analisis korelasi dan regresi linier Malondialdehida (MDA) merupakan senyawa diperoleh koefisien korelasi (r), koefisien hasil peroksidasi lipid yang umumnya determinasi $\left(\mathrm{r}^{2}\right)$ dan persamaan regresi antara digunakan sebagai indikator terjadinya stres kadar MDA testis dengan jumlah spermatozoa, oksidatif. Pada penelitian ini dilakukan persentase motilitas dan morfologi normal pengukuran konsentrasi MDA testis tikus jantan spermatozoa tikus putih DM dapat dilihat pada pada setiap kelompok perlakuan untuk Tabel 9.

Berdasarkan Tabel 9 hasil analisis korelasi pearson di atas menunjukkan bahwa terdapat hubungan yang nyata $(\mathrm{p}=0,000)$ antara kadar MDA testis dengan jumlah spermatozoa, persentase motilitas dan morfologi normal spermatozoa dengan nilai koefisien korelasi (r) berturut-turut adalah-0,877; -0,804 dan -0,795. Nilai koefisien korelasi ( $\mathrm{r}=-0,877 ;-0,804$ dan -0,795) adalah kuat yang artinya keeratan hubungan kadar MDA testis dengan jumlah spermatozoa sebesar $87,70 \%$, persentase motilitas $(80,40 \%)$ dan morfologi normal spermatozoa $(79,50 \%)$. Nilai negatif pada (r) menunjukkan arah korelasi negatif yang menunjukkan semakin rendah kadar MDA testis, maka jumlah spermatozoa, persentase motilitas dan morfologi normal spermatozoa semakin meningkat.

mengetahui perbandingan kadar MDA testis tikus putih normal dengan tikus putih DM yang diinduksi aloksan. Malondialdehid terbentuk dari peroksidasi lemak (lipid peroxidation) pada membran sel yaitu reaksi radikal hidroksi $\left(\mathrm{OH}^{-}\right.$ ) dengan Poly Unsaturated Fatty Acid (PUFA). Reaksi tersebut terjadi secara berantai, akibat akhir dari reaksi rantai tersebut akan terbentuk hidrogen peroksida. Hidrogen peroksida tersebut dapat menyebabkan dekomposisi beberapa produk aldehid yang bersifat toksik terhadap sel dan berpengaruh terhadap gangguan kesuburan testis. ${ }^{23}$

Hasil ini membuktikan bahwa tikus putih DM dapat meningkatkan kadar MDA serum. Meningkatnya kadar MDA serum darah tikus putih pada kelompok perlakuan DM (KP) pada penelitian ini kemungkinan disebabkan terjadinya peningkatan ROS dalam sirkulasi. Hasil ini sejalan dengan hasil penelitian yang 
dilaporkan oleh beberapa peneliti sebelumnya bahwa induksi aloksan dapat menyebabkan hiperglikemia dan berperan penting dalam peningkatan produksi ROS dan peroksidasi lipid yang berlebihan pada tingkat jaringan. ${ }^{29}$ Lebih lanjut Suarsana dkk. menyatakan tingginya kadar glukosa darah meningkatkan pembentukan ROS, melalui reaksi oksidasi reduksi sehingga mendorong lebih banyak donor elektron $\mathrm{NADH}$ dan $\mathrm{FADH}_{2}$ masuk ke dalam rantai transport elektron. Peningkatan laju transport elektron turut berkontribusi dalam peningkatan pembentukan anion superoksida $\left(\mathrm{O}^{-}\right)$salah satu unsur ROS sehingga terjadi stress oksidatif. ${ }^{30,38}$ Stres oksidatif yang terjadi pada kondisi hyperglikemik berasal dari peningkatan produksi ROS di mitokondria melalui mekanisme autooksidasi glukosa, glikasi non-enzimatik, aktivasi protein kinase $\mathrm{C}$ (PKC), aktivasi hexosamine pathway enzimatik, rendahnya konsentrasi antioksidan di jaringan, serta gangguan aktivitas pertahanan antioksidan enzimatik seperti superoksida dismutase (SOD), gluthation peroksidase (GPx) dan catalase (CAT). ${ }^{39,40}$

Pada kondisi hyperglikemia, peningkatan produksi ROS yang melebihi kapasitas antioksidan sel menyebabkan peningkatan stres oksidatif yang diiringi dengan terjadinya peroksidasi lipid pada membran sel sehingga akan meningkatkan malondialdehid (MDA) sebagai hasil peroksidasi lipid. ${ }^{29,34,35}$ Telah dilaporkan bahwa MDA secara sistemik memiliki hubungan parameter metabolik pada subjek diabetes tipe I dan II. Pasien dengan kontrol metabolik yang buruk, akan menunjukkan konsentrasi MDA plasma tertinggi, berbeda secara signifikan dengan kelompok pasien kontrol metabolik yang lebih baik. Lebih lanjut beliau juga menjelaskan bahwa peningkatan kadar MDA secara sangat signifikan berkorelasi dengan lamanya pasien menderita DM. ${ }^{19}$

Hasil uji T independent, diketahui bahwa pada tikus putih normal $(\mathrm{KN})$ memiliki nilai rata-rata konsentrasi MDA $(3,55 \pm 0,62 \mathrm{nmol} / \mathrm{mg})$ yang lebih rendah secara signifikan $(\mathrm{p}=0,000)$ dari pada kelompok tikus putih diabetes $(5,35 \pm 0,53$ nmol/mg). Kadar MDA pada kelompok tikus putih DM (KP) yang lebih tinggi dibandingkan kelompok tikus putih normal (KN) mengindikasikan bahwa tikus putih DM mengalami stres oksidatif.Hal ini dapat terjadi karena pada kelompok tikus putih DM diinduksi dengan aloksan. Aloksan dapat menyebabkan gangguan sekresi insulin pada sel 
beta pancreas, ${ }^{37,38,39}$ serta gangguan histopatologi pankreas. ${ }^{40} \mathrm{Hal}$ ini didukung juga oleh pernyataan Radenkovic et al, yang menyatakan bahwa aloksan bersifat hidrofilik sehingga tidak dapat masuk melalui membran sel. Namun aloksan dapat masuk ke dalam sel beta pankreas melalui protein saluran glukosa (GLUT 2) karena aloksan memiliki struktur seperti glukosa. Masuknya aloksan ke dalam sel beta pankreas menyebabkan inaktivasi enzim glukokinase untuk menstimulus sekresi insulin. Kondisi hiperglikemik memicu peningkatan produksi ROS melalui mekanisme antara lain glikasi non-enzimatik, aktivasi hexosamine pathway, dan polyol pathway.3,33,37,42 ROS dapat berikatan dengan polyunsaturated fatty acid (PUFA) pada membran plasma dan menghasilkan MDA yang berlanjut dengan kerusakan sel. ${ }^{34,43}$ Sel-sel pada organ testis, terutama sel spermatozoa, merupakan target utama dari kerusakan yang disebabkan oleh ROS karena sebagian besar sel tersusun atas PUFA. ${ }^{3}$ Berdasarkan referensi tersebut, dapat dijelaskan mengapa konsentrasi MDA pada organ testis tikus putih DM menunjukkan nilai kadar MDA tertinggi. Hal ini juga dikuatkan hasil penelitian Abdulgani dkk yang menemukan bahwa tikus hiperglikemik menunjukkan gejala histopatologi testis tertinggi dan jumlah sel-sel spermatogenesis terendah. Menurut Halliwell dan Gutteridge semakin tinggi kadar MDA semakin tinggi pula tingkat kerusakan sel yang disebabkan oleh stres oksidatif. Sedangkan pada kelompok tikus putih normal memiliki kadar MDA yang lebih rendah dari pada kelompok tikus putih DM. Hal ini dikarenakan tikus putih normal tidak mengalami kondisi hiperglikemik yang menyebabkan produksi ROS berlebih. Walaupun dalam keadaan normal atau sehat MDA pada tikus normal (KN) tetap terbentuk, akan tetapi dalam kadar yang lebih rendah dibandingkan dengan kadar MDA pada keadaan hiperglikemik. ${ }^{40,44}$ Hal ini sesuai dengan pernyataan Pasupathi,bahwa kadar MDA yang merupakan hasil dari lipid peroksida ditemukan juga pada keadaan tubuh normal atau sehat, yang mengindikasikan bahwa ROS juga diproduksi dalam metabolisme di mitokondria pada sel tubuh yang normal. Produksi ROS di organ testis, terutama di tubulus seminiferus merupakan proses fisiologis normal yang berperan dalam proses fisiologi. Akan tetapi, produksi ROS yang berlebihan menyebabkan terganggunya fungsi sel hingga menyebabkan kerusakan sel. ${ }^{45,46,47}$ 


\section{Kualitas spermatozoa}

Penilaian kualitas spermatozoa tikus putih pada penelitian ini diamati berdasarkan pada jumlah spermatozoa, persentase motilitas spermatozoa dan persentase morfologi abnormal spermatozoa. Rata-rata jumlah spermatozoa tikus putih normal $(\mathrm{KN})$ adalah $252,56 \pm 22,32$ x $10^{6} / \mathrm{ml}$ lebih tinggi dibandingkan dengan jumlah spermatozoa pada kelompok tikus putih DM yang diinduksi aloksan (KP) yaitu 168,25 \pm 17,52x 106/ml. Hasil uji t-independent terhadap jumlah spermatozoa menunjukan ada perbedaan yang bermakna $(\mathrm{p}<0,05)$ diantara kelompok tikus putih normal dengan tikus putih DM. Hasil ini membuktikan bahwa perlakuan DM dengan penyuntikan aloksan berpengaruh terhadap penurunan jumlah spermatozoa tikus putih strain Wistar. Hasil ini sejalan dengan beberapa hasil penelitian sebelumnya yang menemukan penurunan yang signifikan jumlah spermatozoa tikus yang menderita DM.

Menurunnya jumlah spermatozoa pada kelompok tikus putih DM yang diinduksi aloksan pada penelitian ini diduga disebabkan oleh peningkatan produksi ROS yang berlebihan pada tingkat sel. Peningkatan produksi ROS yang berlebihan tanpa diikuti kesimbangan aktivitas antioksidan endogen, menyebabkan terjadinya stress oksidiatif pada sel termasuk sel testis. Hal ini sesuai dengan penelitian yang dilakukan oleh Aitken dkk.membuktikan bahwa kondisi hiperglikemia pada pasien diabetes melitus menyebabkan peningkatan produksi ROS sekaligus penurunan aktivitas dari enzim antioksidan seperti SOD, GSH-Px dan CAT. Pembentukan ROS sebenarnya adalah proses fisiologi tubuh akan tetapi jika peningkatan ROS secara berlebihan tanpa diimbangi dengan antioksidan maka akan menyebabkan stres oksidatif pada sel yang selanjutnya akan menyebabkan peroksidasi lipid dan kerusakan dari sel dalam tubulus seminiferus, termasuk sel Leydig dan sel Sertoli. ${ }^{16,31,35,48}$ Lebih lanjut Argawal, menyatakan bahwa stress oksidatif juga dapat merusak integritas DNA pada nukleus spermatozoa sehingga menginduksi apoptosis sel yang mengakibatkan turunnya jumlah spermatozoa. Hal ini juga didukung oleh Faranita bahwa apoptosis sel menurunkan jumlah spermatozoa. Pada penelitian lain juga dilaporkan, stress oksidatif akibat DM dapat menyebabkan ketidakseimbangan poros hipotalamus-hipofisa-gonad yang selanjutnya mempengaruhi sekresi dan kerja Follikel 
Stimulating Hormone (FSH) dan Luteinizing Hormone (LH). ${ }^{16,49}$ FSH merupakan hormon gonadotropin berperan pada tahap perkembangan sel spermatogonia dan spermatosit primer. FSH mempengaruhi aktifitas mitosis dan proliferasi sel spermatogonia dan menunjang tahap pematangan termasuk reduksi meiosis sel spermatosis dan perkembangan spermatid hingga terbentuk spermatozoa. Sedangkan LH merupakan hormon testosteron yang akan mempengaruhi proses spermatogenesis. Bila terjadi penurunan jumlah sel leydig maka akan terjadi penurunan hormon testosteron yang akan menghambat proses spermatogenesis dan penurunan jumlah spermatozoa. ${ }^{22,48,50,51}$

Rata-rata persentase motilitas spermatozoa tikus putih DM yang diinduksi aloksan (KP) adalah $\quad 58,56 \pm \quad 4,37 \%$ lebih rendah dibandingkan dengan persentase motilitas spermatozoa pada tikus putih normal (KN) yaitu $87,13 \pm 3,81 \%$. Hasil uji t terhadap persentase motilitas spermatozoa menunjukan ada perbedaan yang nyata diantara kelompok tikus putih normal dengan tikus putih DM. Hasil ini membuktikan bahwa perlakuan DM dengan penyuntikan aloksan dapat menurunkan persentase motilitas spermatozoa tikus putih.
Hasil ini sejalan dengan laporan beberapa penelitian sebelumnya yang menemukan adanya penurunan persentase motilitas spermatozoa yang bermakna pada penderita DM dibandingkan dengan kondisi normal.

Menurunnya persentase motilitas spermatozoa tikus putih pada kelompok perlakuan DM dengan penyuntikan aloksan disebabkan terjadinya peningkatan ROS dalam sirkulasi. Hasil ini sejalan dengan hasil penelitian yang dilaporkan oleh beberapa peneliti sebelumnya bahwa pemberian diet tinggi lemak dapat menyebabkan hiperlipidemia berperan penting dalam peningkatan produksi radikal bebas dan peroksidasi lipid yang berlebihan pada tingkat jaringan. Tingginya kadar radikal bebas dalam sirkulasi akan merusak membran sel spermatozoa (akrosom)dan menyebabkan gangguan gerak spermatozoa dan penurunan motilitas spermatozoa. ${ }^{52}$ Hiperglikemia punya pengaruh terhadap sel epitel germinal dalam tubuli seminiferi testis, sehingga sel epitel germinal yang dihasilkan terganggu pertumbuhan dan perkembangannya. Terganggunya pertumbuhan dan perkembangan sel epitel germinal tersebut akhirnya akan menyebabkan spermatozoa yang dihasilkan belum masak, hal ini akan berpengaruh 
terhadap energi yang dihasilkan yang kemudian menghasilkan motilitas yang kurang baik. Spermatozoa yang belum masak mempunyai mitokondria yang belum sempurna susunannya (tidak melingkar), sehingga tenaga yang dihasilkan bukan merupakan energi yang terotasi. Akibatnya energi yang dihasilkan tidak efisien untuk mengerakkan ekor. Di lain pihak pada keadaan hiperkolesterolemia terjadi penurunanan aktivitas enzim 17-beta hydroxysteroid dehydrogenase serta menurunnya enzim antioksidan (SOD, Catalase, GSH, glutathione peroxidase), hal ini semakin mendukung terjadinya penurunan kualitas maupun motilitas spermatozoa. Pada penelitian lain juga dilaporkan, pada keadaan hiperkolesterolemia terjadi kelainan morfologi spermatozoa dikarenakan terjadinya gangguan pematangan dan gangguan pada proses sintesis hormon sehingga menyebabkan gangguan pada proses pembentukan spermatozoa. Adanya kelainan morfologi spermatozoa akan berpengaruh terhadap motilitas spermatozoa. ${ }^{16,22}$

Rata-rata persentase morfologi normal spermatozoa tikus putih strain Wistar normal (KN) adalah $91,85 \pm \quad 1,19 \%$ mengalami penurunan pada perlakuan tikus DM (KP) menjadi $82,94 \pm 2,56 \%$. Hasil uji t terhadap persentase morfologi abnormal spermatozoa menunjukan ada perbedaan yang nyata $(\mathrm{p}=0,000)$ antara kelompok tikus putih normal dibandingkan dengan tikus putih DM. Hasil ini membuktikan bahwa DM dapat menurunkan persentase morfologi normal spermatozoa tikus putih. Menurunnya persentase morfologi normal spermatozoa tikus putih pada kelompok perlakuan tikus putih DM (KP) disebabkan terjadinya peningkatan ROS dalam sirkulasi. Hasil ini sejalan dengan hasil penelitian yang dilaporkan oleh beberapa peneliti sebelumnya bahwa induksi aloksan dapat menyebabkan hiperglikemia yang secara klinis mirip seperti DM tipe 1, peningkatan produksi ROS dan peroksidasi lipid yang berlebihan pada tingkat jaringan. Tingginya kadar ROSdalam sirkulasi akan merusak membran sel spermatozoa dan menyebabkan gangguan penyempurnaan bentuk spermatozoa pada tahap spermiogenesis. ${ }^{22,31}$ Selain itu juga diakibatkan terjadi penurunan sekresi testosteron dari sel Leydig sehingga kadar testosteron dalam darah menjadi rendah yang selanjutnya akan menyebabkan proses spermiogenesis tidak berjalan optimal, yang pada akhirnya morfologi spermatozoa menjadi tidak sempurna. ${ }^{53,53,55,56}$ 
Hubungan Kadar MDA dengan Kualitas

\section{Spermatozoa}

Hasil analisis korelasi pearson menunjukkan adanya hubungan yang antara kadar MDA testis dengan jumlah spermatozoa, persentase motilitas dan morfologi normal spermatozoa tikus putih dengan nilai korelasi (r) secara bertutur-turut adalah - 0,877; - 0,804 dan 0,795. Hasil ini membuktikan bahwa terdapat hubungan antara kadar MDA testis dengan jumlah spermatozoa, persentase motilitas dan morfologi normal spermatozoa adalah kuat secara berturut-turut sebesar $87,70 \% ; 80,40 \%$ dan 79,50\%. Nilai negatif pada nilai korelasi (r) menunjukkan arah korelasi negatif yang berarti bahwa semakin rendah kadar MDA testis akan menyebabkan semakin meningkat jumlah spermatozoa, persentase motilitas dan morfologi normal spermatozoa. Hasil penelitian ini menunjukkan bahwa diabetes mellitus tipe 1 meningkatkan terjadinya peroksidasi lipid pada testis yang ditunjukan dengan meningkatnya kadar MDA testis. Peningkatan kadar MDA testis menyebabkan gangguan proses spermatogenesis di tubulus seminiferus testis yang selanjutnya akan menurunkan jumlah spermatozoa, penurunan motilitas dan morfologi normal spermatozoa. Sebagaimana dilaporkan oleh beberapa peneliti terdahulu bahwa MDA sebagai produk akhir dapat digunakan untuk mengetahui derajatkerusakan oksidatif yang disebabkan oleh peroksidasi lipid. Peroksidasi lipid hasil dari radikal bebas ini akan selalu membentuk reaksi berantai yang terus berlanjut sampai radikal bebas ini dihilangkan oleh radikal bebas lain dan oleh sistem antioksidan dari tubuh. ${ }^{57}$ Malondialdehida umum digunakan sebagai biomarker biologis peroksidasi lipid dan menggambarkan derajat stres oksidatif pada jaringan termasuk testis ${ }^{58}$. Diabetes melitus juga mempengaruhi fungsi reproduksi pria seperti terganggunya proses spermatogenesis. ${ }^{59}$ Stres oksidatif yang terjadi pada diabetes melitus berkaitan erat dengan infertilitas karena memiliki pengaruh yang cukup besar terhadap disfungsi sperma. Sebanyak 40,88\% pasien pria diabetes yang mengalami infertilitas, memiliki sperma dengan kadar ROS yang tinggi. ${ }^{60}$ Kadar ROS berlebih mampu mempengaruhi kualitas dan fungsi sperma. Spermatozoa mudah terserang oleh induksi stres oksidatif karena dalam membran plasmanya banyak terkandung asam lemak tak jenuh rantai ganda. Stres oksidatif merusakintegritas DNA di inti spermatozoa, akan menginduksi terjadinya apoptosis sel spermatozoa. Apoptosis adalah 
kematian sel spermatozoa terprogram dimana proses ini merupakan proses fisiologis yang ditentukan oleh perubahan morfologi dan biokimia sel spermatozoa. Proses ini diregulasi oleh faktor intrinsik dan ekstrinsik, dan dapat dirangsang oleh berbagai stimulus. Pada pria infertil ditemukan adanya peningkatan apoptosis sel spermatozoa, yang pada akhirnya menyebabkan menurunnyajumlah spermatozoa, motilitas spermatozoa serta menyebabkan perubahan morfologi spermatozoa. ${ }^{58,59,60,61}$ Maxwell dan Watson menyatakan bahwa plasma membran spermatozoa kaya asam lemak tak jenuh sehingga rentan terhadap kerusakan peroksidasi lipid. MDA merupakan hasil dari peroksidasi lipid oleh ROS. ${ }^{62}$ Pengukuran kadar MDA merupakan cara pengukuran aktivitas ROS secara tidak langsung, karena yang diukur adalah produk dari ROS. Peningkatan ROS menyebabkan terjadinya peroksidasi lipid, adanya peroksidasi lipid pada membran spermatozoa menghasilkan senyawa MDA. Dengan demikian kadar MDA yang tinggi menunjukkan terjadinya kerusakan membran spermatozoa. Keadaan ini diindikasikan dengan menurunnya jumlah spermatozoa yang dihasilkan. Hal ini sesuai dengan Helliwell dan Gutteridge, yang menyatakan bahwa semakin tinggi kadar MDA semakin tinggi pula tingkat kerusakan sel yang disebabkan oleh stres oksidatif. $44,57,58,59 \quad$ Sejumlah penelitian telah menunjukkan bahwa lipidperoksidasi mempengaruhi jumlah,motilitas, morfologi spermatozoa. ${ }^{63,64}$ Colagar dkk. tahun 2009 menunjukkan bahwa kadar MDA dalam spermatozoa adalahsecara signifikan terkait dengan jumlah spermatozoa immotil ${ }^{20}$. Telah terbukti bahwa konsentrasi MDA dalam plasma seminal berkorelasi negatif dengan konsentrasi sperma, motilitas dan morfologi normal antara subur dan pria infertil..$^{65,66,67}$ Beberapa penelitian lain juga menyatakan bahwa ROS menyerang integritas DNA dalam inti sperma dengan menyebabkan modifikasi dasar, untai DNA rusak dan chromatin cross-linking. ${ }^{68,69} \mathrm{Di}$ sisi lain, kerusakan DNA akibat peningkatan kadar ROS yang berlebihan mempercepat proses apoptosis sel germinal, menyebabkan penurunan jumlah spermatozoa dan motilitas spermatozoa pria infertilitas ${ }^{70,71,72}$ Motilitas adalah sangat diperlukan untuk spermatozoa, seperti yang seharusnya perjalanan saluran reproduksi wanita untuk mencapai tempat pembuahan. Studi telah menemukan bahwa tingkat ROS berkorelasi dengan motilitas spermatozoa. Kerusakan peroxidative pada protein membran spermatozoa dan aksonemal 
menyebabkan kerusakan permanen pada motilitas spermatozoa. ${ }^{70}$ ROS yang berlebihan menyebabkan ATP berkurang dengan cepatmengakibatkan penurunan fosforilasi protein aksonemal dan menyebabkan kerusakan sementara motilitas. ${ }^{71}$ Peroksidasi lipid juga memiliki efek merusak status ultramorphological dari sel spermatozoa. ${ }^{71,72}$ Hasil penelitian ini menunjukkan bahwa terdapat hubungan negatif antara peningkatan kadar MDA testis dengan kualitas spermatozoa tikus putih yang mengalami diabetes, mellitus. Temuan ini sejalan dengan hasil beberapa penelitian lain, bahwa peningkatan kadar MDA testis berhubungan dengan tingginya persentase spermatozoa abnormal dan produksi ROS. ${ }^{20,68,73}$ Temuan ini menunjukan bahwa stres oksidatif pada tikus putih diabetes terlibat dalam peningkatan kadar MDA testis dan penurunan kualitas spermatozoa. Ukuran kadar MDA testis bisa sebagai alat diagnostik yang berguna untuk estimasi penurunan kualitas spermatozoa pada penderita diabetes mellitus.

\section{Kesimpulan}

Berdasarkan hasil analisis dan pembahasan yang telah diuraikan oleh peneliti, dapat diambil kesimpulan bahwa terdapat hubungan yang kuat antara kadar MDA testis dengan kualitas (jumlah, motilitas dan morfologi normal) spermatozoa tikus putih diabetes mellitus $(\mathrm{R}=$ 0,877; - 0,804 dan - 0,795). Semakin tinggi kadar MDA testis semakin rendah jumlah, persentase motilitas dan morfologi normal spermatozoa tikus putih diabetes.

\section{Saran}

Berdasarkan hasil penelitian ini dapat disampaikan bahwa perlu dilakukan penelitian lebih lanjut untuk mengetahui faktor-faktor lain yang dapat menentukan jumlah spermatozoa akibat DM, seperti aktivitas antioksidan endogen (SOD, Gpx, dan CAT) dalam serum.

\section{Daftar Referensi}

1. Soviana, E., Banundari, R., dan Nyoman, S. W. Pengaruh Suplementasi $\beta$-carotene Terhadap Kadar Glukosa Darah dan Kadar Malondialdehida pada Tikus Sprague dawley yang Diinduksi Streptozotocin. Jurnal Gizi Indonesia 2014;2(2): 4146.

2. Enzlin P, Mathieu C, Van den Bruel A, Vanderschueren D, Demyttenaere K. Prevalence and Predictors of Sexual 
Dysfunction in Patients with Type 1 Diabettes . Belgium. Available from : URL :http://www.care.

diabetesjournals. org/cgi/content/full/26/2/409; 2003.

3. Amaral, S., Oliveira, P. J., and Ramalho, J. Diabetes and the Impairment of Reproductive Function: Possible Role of Mitochondria and Reactive Oxygen Species. Current Diabetes Reviews 2008; 4(1): 46-54.

4. PERKEMI. Konsensus Pengelolaan Diabetes Melitus Tipe 2 di Indonesia 2002. Semarang. 2002; p 6-7.

5. Amaral, S., Moreno, A. J., Santos, M. S., Seica, R., and Santos, J. R.

Effects of Hyperglycemia on Sperm and Testicular Cells of Goto-Kakizaki and Streptozotocin-Treated Rat Models for Diabetes. Theriogenology 2006; 66: 2056-2067.

6. Kanter, M., Aktas, C., and Erboga, M. 2012. Protective Affects of Quercetin Against Apoptosis and Oxidative Stress in Streptozotocin-Induced Diabetic Rat Testis. Food Chem Toxicol 50: 719-725.

7. Agarwal A, Cocuzza M, Abdelrazik H, Sharma RK. Oxidative stress measurement in patients with male or female factor infertility. Handbook of Chemiluminescent Methods in Oxidative Stress Assessment. 2008. p. 195-218.

8. Maslachah, L., Sugihartuti, R., dan Kurniasanti, R. Hambatan Produksi Reactive Oxygen Species Radikal Superoksida (O2-) oleh Antioksidan Vitamin E ( $\alpha$-Tocopherol) pada TIkus Putih (Rattus norvegicus) yang Menerima Stressor Renjatan Listrik. Media Kedokteran Hewan. 2008; 24(1): 21-26.

9. Darmawan H. 2007. Production of ROS and Its Effects on Mitochondrial and Nuclear DNA, Human

Spermatozoa, and Sperm Function. Medical Journal Indonesia.; 16: 2.

10. Noberasco G, Odetti P, Boeri D, Maiello M, Adezati L. Malondialdehyde (MDA) level in diabetic subjects. Relationship with blood glucose and glycosylated hemoglobin. Biomedicine \& Pharmacotherapy. 1991;45(4):193-6.

11. Siswonoto S. Hubungan Kadar Malondialdehid Plasma dengan Keluaran Klinis Stroke Iskemik Akut: Program Pasca Sarjana Universitas Diponegoro; 2008. 
12. Ni K, Steger K, Yang H, Wang H, Hu $\mathrm{K}$, Zhang $\mathrm{T}$, et al. A comprehensive investigation of sperm DNA damage and oxidative stress injury in infertile patients with subclinical, normozoospermic, and astheno/oligozoospermic clinical varicocoele. Andrology. 2016;4(5):81624

13. Tavilani H, Doosti M, Saeidi H. Malondialdehyde levels in sperm and seminal plasma of asthenozoospermic and its relationship with semen parameters. Clinica Chimica Acta. 2005;356(1):199-203.

14. Jungwirth A, Giwercman A, Tournaye H, Diemer T, Kopa Z, Dohle G, et al. European Association of Urology guidelines on Male Infertility: the 2012 update. European urology. 2012;62(2):324-32.

15. Medicine PCotASfR. Diagnostic evaluation of the infertile male: a committee opinion. Fertility and sterility. 2012;98(2):294-301.

16. Agarwal A, Durairajanayagam D, Halabi J, Peng J, Vazquez-Levin M. Proteomics, oxidative stress and male infertility. Reproductive biomedicine online. 2014;29(1):32-58.
17. Benedetti S, Tagliamonte MC, Catalani S, Primiterra M, Canestrari F, De Stefani S, et al. Differences in blood and semen oxidative status in fertile and infertile men, and their relationship with sperm quality. Reproductive biomedicine online. 2012;25(3):300-6.

18. Bhutia Y, Ghosh A, Sherpa ML, Pal R, Mohanta PK. Serum malondialdehyde level: Surrogate stress marker in the Sikkimese diabetics. Journal of Natural Science, Biology, and Medicine. 2011;2(1):107-12.

19. Nakhjavani M, Esteghamati A, Nowroozi S, Asgarani F, Rashidi A, Khalilzadeh O. Type 2 diabetes mellitus duration: an independent predictor of serum malondialdehyde levels. Singapore medical journal. 2010;51(7):582-5.

20. Colagar AH, Pouramir M, Marzony ET, Jorsaraei SGA. Relationship between seminal malondialdehyde levels and sperm quality in fertile and infertile men. Brazilian Archives of Biology and Technology. 2009;52(6):1387-92.

21. Akbar B. Tumbuhan dengan kandungan senyawa aktif yang berpotensi sebagai bahan antifertilitas. Adabia Press; 2013. 
22. Guyton Arthur C, Hall JE. Buku Ajar Fisiologi Kedokteran, edisi 11. Jakarta: EGC; 2007.

23. Austin CR, Short RV. Reproduction in mammals: Cambridge University Press; 2005

24. Group IRTD. Rat Sperm Morphological Assessment. $1^{\text {st }}$ ed.2000. p. 1-15.

25. HIFERI, PERFITRI, IAUI, POGI. Konsensus penanganan infertilitas. Jakarta2013.

26. Cavallini G. Male Idiopathic (Oligo) \pm (Astheno) $\quad \pm$ (Terato)-Spermia. In: Cavallini G, Beretta G, editors. Clinical Management of Male Infertility. London: Springer; 2015. p. 79-85.

27. Coskun O, Ocakci Ayse, Bayraktaroglu $\mathrm{T}$, and Kanter M. Exercise Training Prevents and Protects StreptozotocinInduced Oxidative Stress and $\beta$-Cell Damage in Rat Pancreas. Departement of Medical Histology and Embryology. Turkey: Zonguldak Karaelmas University. 2004.

28. Coskun Z.M, Sacanc O, Karatugd A, Turka N, Refiye Yanardagc R, Bolkentd $\mathrm{S}$ and Bolkenta S. Regulation of oxidative stress and somatostatin, cholecystokinin, apelin gene expressions by ghrelin in stomach of newborn diabetic rats. ACTHIS,2013; 50697-50704.

29. Suparman, E. Kadar Lipid Peroksida pada Kehamilan Normotensi dan Preeklampasia. Majalah Obstetri \& Ginekologi2012; 20: 65-71.

30. Suarsana IN, I.H. Utama, I.G. Agung dan A. Suartini. 2011. Pengaruh hiperglikemia dan vitamin E pada kadar malonaldehida dan enzim antioksidan intra sel jaringan pankreatikus. Majalah Kedokteran Bandung 43(2):72-6.

31. Aitken, R. J. and Roman, S. D. Antioxidant System andOxidative Stress in The Testes. Oxidative Medicine and Cellular Longevity, 2008:1(1): 15-24.

32. Evans J.L, Goldfine I.D, Maddux B.A and Grodsky G.M. (2002): Oxidative stress and stress activated signaling pathways: A unifying hypothesis of type 2 diabetes. Endo. Rev., 23: 599-622.

33. Tang, W. H., Martin, K. A., and Hwa, J. Aldose Reductase,Oxidative Stress, and Diabetic Mellitus. Frontiers in Pharmacology: Experimental Pharmacology and Drug Discovery, 2012; Vol 3 Article 87.

34. Palmeira, C. M., Santos, D. L., Seica, R., Moreno, A. J., andSantos, M. S. 
Enhanced Mitochondrial Testicular Antioxidant Capacity in Goto-Kakizaki Diabetic Rats: Role of Coenzyme Q. Am J Physiol Cell Physiol. 2001: 281: 1023-1028.

35. Kumar, V., Abdul, K. A., and Nelson, F. Robbins and Cotran Pathologic Basis of Disease 7th Edition. Philadelphia:Elsevier Sauders. 2005.

36. Jyoti, A. and Anand, K. Chronic Treatment od Diabecon in The Regulation of Alloxan Induced Hyperglycemia and Oxidative Stress in Different Tissues of Adolescent Diabetic Rats.International Journal of Pharmacy and Pharmaceutical Sciences 2014; 6(4): 83-87.

37. Radenkovic, M., Stojanovic, M., and Prostran, M. Experimental Diabetes Induced by Alloxan and Streptozotocin:The Current State of The Art. Journal of Pharmacological andToxicological Methods 2016: 78: $13-31$.

38. Rohilla, A. and Ali, S. Alloxan Induced Diabetes: Mechanisms and Effects. International Journal of Research in Pharmaceutical and Biomedical Sciences 2012 ; 3(2): 819-823.
39. Szkudelski, T. The Mechanism of Alloxan and Streptozotocin Action in B Cells of the Rat Pancreas. Physiol Res 2001; 50: 536-543.

40. Abdulgani, N dan Maharani, L. Potensi Regenerasi Sel Leydig dan Sel Spermatogenik pada Testis Mencit Mencit (Musmusculus) Hiperglikemik yang Diinduksi dengan Ekstrak Ikan Gabus (Channa striata). Tugas Akhir. Surabaya: ITS.2014.

41. Abdulgani, N., Trisnawati, I., Aunurohim, Hidayati, D.,Aisyatussoffi, N., \& Arifiyanto, A. Snakehead (Channastriata) Extracts Treatment towards Hyperglycemic Mice (Musmusculus) Blood Glucose Levelsand Pancreatic Histology Structure. Journal of Applied Environmental and Biological Sciences. 2014;4(5): 1-6.

42. Setiawan, B dan Suhartono, E. Stress Oksidatif dan Peran Antioksidan pada Diabetes Melitus. Majalah Kedokteran Indonesia. 2005; Vol 55 No 2.

43. Grotto, D., Maria, L. S.,Valentini, J., Paniz, C., and Garcia. Importance of The Lipid Peroxidation Biomarkers an Methodological Aspects For 
Malondialdehyde Quantification. Quin Nova 2009; 32(1): 169-174.

44. Halliwell, B. and Gutteridge, J. M. C. Free Radical in Biology and Medicine 3rd ed. New York: Oxford University Press. 1999.

45. Pasupathi, P. Glutathione, GlutathioneDependent Enzymesand Antioxidant Status in Gastric Carcinoma Patients. Journal of Applied Biomedicine, 2009:7(2): 101-109.

46. Koksal, I. T., Usta, M., Orhan, I., Abbasoglu, S., Kadioglu, A.Potential Role of Reactive Oxygen Species on Testicular Pathology Associated With Infertility. Asian J Androl 2003; 5: 9599.

47. Shayakhmetova, G. M., Bondarenko, L. B., and Kovalenko, V.M. Damage of Testicular Cell Macromolecules and Reproductive Capacity of Male Rats Following Co-Administration of Ethambutol, Rifampicin, Isoniazid Acid and Pyrazinamide. Interdiscip Toxicol, 2012:5(1): 9-14.

48. Idris M.H, Budin S.B, Osman M and Mohamed J. (2012): protective role of hibiscus sabdariffa calyx extract against streptozotocin induced sperm damage in diabetic rats. EXCLI Journal, 11:659669.

49. Faranita, O.V. Kualitas Spermatozoa Pada Tikus Wistar Jantan Diabetes Melitus. Skripsi. Fakultas Kedokteran, Universitas Diponegoro, Semarang. 2009.

50. Sherwood L. Fisiologi Manusia dari Sel ke Sistem Edisi 2. Jakarta: EGC;2001

51. Remzi Cevik, Ali Gur, Suat Acar, Kemal Nas and Ayegül Jale Sarac. (2004). Hypothalamic pituitarygonadal axis hormones and cortisol in both menstrual phases of women with chronicfatigue syndrome and effect of depressive moodon these hormones. BMC Musculoskelet. Disord.5, 47-51.

52. Shofia, V., Aulanni'am, dan C. Mahdi.2013,

StudiPemberianEkstrakRumputLautCo klat (SargassumPrismaticum) terhadap Kadar

MalondialdehiddanGambaranHistologi JaringanGinjalpadaTikus

(RattusNorvegicus) Diabetes MelitusTipe 1.KimiaStudent Journal. 1(1): $119-125$

53. GlennD,BraunsteinMD.Testis.Didala m:GreenspanF.S,StrewlerG.J. Endokri 
nologi dasar \&klinik,ed.4. Jakarta:EGC, 1995:508-14

54. Matsumoto AM. The testis.In: Felig P, Frohman LA, editors. Endocrinology \& metabolism, $4^{\text {th }}$ ed.USA: The McGraw-Hill Companies Inc., 2001:635-58

55. Silva PFN, Gadella BM. Detection of damage in mammalian sperm cells. Theriogenology 2006.65:958-978.

56. Salisbury,N.LdanVan Demark. Fisiologi dan Reproduksi Pada Sapi. Gadjah Mada University Press, Yogyakarta (Diterjemahkan oleh R.Djanuar). 1985.

57. Saxena, R. and Lal, A.M. Effect of Aging on Antioxidant Enzyme Status and LipidPeroxidation. Journal of The Indian Academy of Geriartrics. 2006; Vol 2 No 2

58. Hendromartono, S. Peran radikal bebas terhadap komplikasi vaskuler. Majalah Penyakit Dalam Udayana 2000; 1:89-92.

59. Ilyas, S., Ardinata, D., dan Meldawati. Pengaruh Ekstrak Buah Morinda Citrifolia Linn Terhadap Kualitas, Kuantitas Sperma Dan Kadar Malondialdehyde Testis Tikus WistarDiabetes Mellitus.Tesis.
Program Magister Ilmu Biomedik Fakultas Kedokteran. Medan: Universitas Sumatera Utara. 2011

60. Sudoyo, A.W., Setiyohadi, B., Alwi, I., Simadibrata, M., dan Setiyati, K. S. Buku Ajar Ilmu Penyakit Dalam Jilid 3 Edisi 4. Jakarta: Pusat Penerbitan Departemen Penyakit Dalam Fakultas Kedokteran Universitas Indonesia. 2007

61. Tremellen, K. Oxidative Stress and Male Infertility-A Clinical Perspective. Human Reproduction Update, 2008; 14(3): 243-258.

62. Maxwell, W.M. Cand Watson,P.F,.Recent Progresin Preservation of Ram Semen. Animal Reproduction Sci ence. 42. Elsevier.1996

63. Hsieh, Y.Y.; Chang, C.C.; and Lin CS. Seminal malondialdehyde concentration but not glutathione Peroxidase activity is negatively correlated with seminal concentration and motility. Int J Biol Sci., 2006, 2, 239.

64. Huang, Y.L.; Tseng, W.H.; Cheng, S.Y. and Lin, T.S. Trace elements and 
lipid peroxidation in human seminal plasma. Biol Trace Elem Res.,2000, 76, 207-15.

65. Zalata, A.A.; Ahmed, A.H.; Allamaneni, S.S.R.;Comhaire, F.H. and Agarwal, A. Relationship between acrosin activity of human spermatozoa andoxidative stress. Asian J Androl., 2004; 6, 313-18.

66. Duru, N.K.; Morshedi, M. and Oehninger, S. Effects of hydrogen peroxide on DNA and plasma membrane integrity of human spermatozoa. Fert andSteril., 2000; 74, 1200-207.

67. Aitken, R.J. and Baker, M.A. Oxidative stress,sperm survival and fertility control. Mol and CellEndocrin., 2006; 250, 66-69.

68. Agarwal, A. and Prabakaran, S.A. Oxidative stress and antioxidants in male infertility: a difficult balance. Iran J Rep Med., 2005; 3: 1-8.

69. Agarwal, A.; Saleh, R.A. and Bedaiwy, M.A. Role of reactive oxygen species in the pathophysiology of human reproduction. Fert and Steril., 2003; $79,829-43$.

70. Aitken, R.J. and Krausz, C. Oxidative stress, DNA damage and the $\mathrm{Y}$ chromosome. Reprod., 2001; 22,497606.

71. Aleksandra, K.; Slawomir, K. and Ewa, B.Values of malondialdehyde in human seminal plasma. Progress in Med Res., 2004; 2, 1-10.

72. Zabludovsky, N.; Eltes, F.; Geva, E.; Berkovitz, E.;Amit, A.; Barak, Y.; Hareven, D. and Bartoov,B. Relationship between human sperm lipid peroxidation, comprehensive quality parameters and IV outcome. Androl., $1999 ; 31,91-8$ 
Tabel 1.Rerata kadar MDA testis (nmol/mg) tikus putih (Rattus norvegicus) setelah perlakuan selama 60 hari

\begin{tabular}{ccc}
\hline Perlakuan & Ulangan & $\begin{array}{c}\text { Kadar MDA testis } \\
(\mathbf{n m o l} / \mathbf{m g})\end{array}$ \\
\hline Tikus Normal & 16 & $3,55 \pm 0,62$ \\
Tikus DM & 16 & $5,35 \pm 0,53$ \\
\hline
\end{tabular}

Tabel 2.Hasil uji Shapiro-Wilk kadar MDA testis

\begin{tabular}{ccccc}
\hline Kelompok & Ulangan & Mean & SD & P value \\
\hline KN & 16 & 3,55 & 0,62 & 0,626 \\
KP & 16 & 5,35 & 0,53 & 0,212
\end{tabular}

Ket : Nilai $p$ dihitung menggunakan uji Shapiro-Wilk* $p>0.05$ (data terdistribusi normal)

Tabel 3.Hasil uji Levence MDA testis

\begin{tabular}{cccc}
\hline Levene Statistic & df1 & df2 & $P$ value/Sig. \\
\hline 0,351 & 1 & 30 & 0,558
\end{tabular}

Keterangan : Nilai $p$ dihitung menggunakan uji Levence ${ }^{*} p>0.05$ (data tetap homogen)

Tabel 4. Hasil uji t-independent kadar MDA testistikus putih normal dan tikus putih Diabetes

\begin{tabular}{cccccc}
\hline $\begin{array}{c}\text { Kelompok } \\
\text { Perlakuan }\end{array}$ & $\mathrm{n}$ & Rata-rata Kadar MDA & $\mathrm{SD}$ & $\mathrm{T}$ & $p$ \\
\hline Tikus Normal & 16 & 3,55 & 0,62 & 8,795 & 0,000 \\
Tikus DM & 16 & 5,35 & 0,53 & & \\
\hline
\end{tabular}


Tabel 5. Rata-rata ( $\pm \mathrm{SD})$ kualitas spermatozoa tikus putih strain Wistar normal $(\mathrm{KN})$ dan tikus Diabetes Mellitus (KP)

\begin{tabular}{ccccc}
\hline & & \multicolumn{3}{c}{ Kualitas Spermatozoa } \\
\cline { 3 - 5 } Kelompok & Ulangan & Jumlah & Motilitas & Morfologi Normal \\
Perlakuan & & spermatozoa $(\mathrm{x}$ & spermatozoa & spermatozoa (\%) \\
& & $\left.10^{6} / \mathrm{ml}\right)$ & $(\%)$ & $91,85 \pm 1,19$ \\
\hline Tikus Normal & 16 & $252,56 \pm 22,32$ & $87,13 \pm 3,81$ & $82,94 \pm 2,56$ \\
Tikus DM & 16 & $168,25 \pm 17,52$ & $58,56 \pm 4,37$ & \\
\hline
\end{tabular}

Tabel 6. Hasil uji Shapiro-Wilk kualitas spermatozoa (jumlah, motilitas dan morfologi normal) tikus putih

\begin{tabular}{cccccc}
\hline Parameter & Kelompok & Ulangan & Mean & SD & $\boldsymbol{P}$ value \\
\hline Jumlah & KN & 16 & 252,56 & 22,32 & 0,248 \\
Spermatozoa & KP & 16 & 168,25 & 17,52 & 0,947 \\
\hline Motilitas & KN & 16 & 87,13 & 3,81 & 0,218 \\
Spermatozoa & KP & 16 & 58,56 & 4,37 & 0,905 \\
\hline Morfologi & KN & 16 & 91,85 & 1,19 & 0,470 \\
normal & KP & 16 & 82,94 & 2,56 & 0,095 \\
spermatozoa & & & & & \\
\hline
\end{tabular}

Ket : Nilai $p$ dihitung menggunakan uji Shapiro-Wilk*p $>0.05$ (data terdistribusi normal) 
Tabel 7.Hasil uji Levence kualitas spermatozoa (jumlah, motilitas dan morfologi abanormal spermatozoa)

\begin{tabular}{lcccc}
\hline & Levene Statistic & df1 & df2 & Sig. \\
\hline Jumlah Spermatozoa & 0,878 & 1 & 30 & 0,356 \\
\hline Motilitas Spermatozoa & 0,174 & 1 & 30 & 0,679 \\
\hline $\begin{array}{l}\text { Morfologi normal } \\
\text { Spermatozoa }\end{array}$ & 5,388 & 1 & 30 & 0,327 \\
\hline
\end{tabular}

Keterangan : Nilai $p$ dihitung menggunakan uji Levence $* p>0.05$ (data tetap homogen)

Tabel 8. Hasil uji t-independent kualitas (jumlah, persentase motilitas dan morfologi abnormal) spermatozoa tikus putih normal dan tikus putih Diabetes Mellitus tipe 1

\section{Jumlah Spermatozoa}

\begin{tabular}{cccccc}
\hline $\begin{array}{c}\text { Kelompok } \\
\text { Perlakuan }\end{array}$ & $\mathrm{N}$ & Rata-rata & SD & $\mathrm{T}$ & $p$ \\
\hline Tikus Normal & 16 & 252,56 & 22,32 & & \\
Tikus DM & 16 & 168,25 & 17,52 & & 0,000 \\
\hline
\end{tabular}

Persentase Motilitas Spermatozoa

\begin{tabular}{cccccc}
\hline $\begin{array}{c}\text { Kelompok } \\
\text { Perlakuan }\end{array}$ & N & Rata-rata & SD & T & $P$ \\
\hline Tikus Normal & 16 & 87,13 & 3,81 & & \\
Tikus DM & 16 & 58,56 & 4,37 & & 0,000 \\
\hline
\end{tabular}


Persentase Morfologi normal Spermatozoa

\begin{tabular}{cccccc}
\hline $\begin{array}{c}\text { Kelompok } \\
\text { Perlakuan }\end{array}$ & $\mathrm{N}$ & Rata-rata & SD & T & $P$ \\
\hline Tikus Normal & 16 & 91,85 & 1,19 & & \\
Tikus DM & 16 & 82,94 & 2,56 & & 0,000 \\
\hline
\end{tabular}

Tabel 9. Analisis Korelasi Pearson antara kadar MDA testis dengan jumlah, persentase motilitas dan morfologi normal spermatozoa tikus putih strain Wistar

\begin{tabular}{|c|c|c|c|c|c|}
\hline & & Jumlah & Motilitas & Morfologi & MDA \\
\hline Jumlah & Pearson & 1 & $-0,829^{* *}$ & $-0,834^{* *}$ & $-0,877^{* *}$ \\
\hline \multirow[t]{3}{*}{ Sperma } & Correlation & & & & \\
\hline & Sig. (2-tailed) & & 0,000 & 0,000 & 0,000 \\
\hline & $\mathrm{N}$ & 32 & 32 & 32 & 32 \\
\hline \multirow{4}{*}{$\begin{array}{l}\text { Motilitas } \\
\text { sperma }\end{array}$} & Pearson & $-0,829^{* *}$ & 1 & $-0,927^{* *}$ & $-0,804^{* *}$ \\
\hline & Correlation & & & & \\
\hline & Sig. (2-tailed) & ,000 & & 0,000 & 0,000 \\
\hline & $\mathrm{N}$ & 32 & 32 & 32 & 32 \\
\hline \multirow{4}{*}{$\begin{array}{l}\text { Morfologi } \\
\text { normal } \\
\text { sperma }\end{array}$} & Pearson & $-0,834^{* *}$ & $-0,927^{* *}$ & 1 & $-0,795^{* *}$ \\
\hline & Correlation & & & & \\
\hline & Sig. (2-tailed) & 0,000 & 0,000 & & 0,000 \\
\hline & $\mathrm{N}$ & 32 & 32 & 32 & 32 \\
\hline \multirow{4}{*}{$\begin{array}{l}\text { Kadar } \\
\text { MDA testis }\end{array}$} & Pearson & $-0,877^{* *}$ & $-0,804^{* *}$ & $-0,795^{* *}$ & 1 \\
\hline & Correlation & & & & \\
\hline & Sig. (2-tailed) & 0,000 & 0,000 & 0,000 & \\
\hline & $\mathrm{N}$ & 32 & 32 & 32 & 32 \\
\hline
\end{tabular}

